\title{
A Side-by-Side Energy Use Comparison of a Variable-Speed Small Duct High Velocity and Two-Stage Conventional Ducted Heat Pump in a Net-Zero Energy Home
}

\author{
W. Vance Payne \\ Brian P. Dougherty
}

This publication is available free of charge from:

https://doi.org/10.6028/NIST.TN.2101

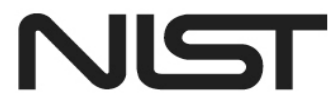

National Institute of Standards and Technology U.S. Department of Commerce 


\title{
A Side-by-Side Energy Use Comparison of a Variable-Speed Small Duct High Velocity and Two-Stage Conventional Ducted Heat Pump in a Net-Zero Energy Home
}

\author{
W. Vance Payne \\ Brian P. Dougherty \\ Energy and Environment Division \\ Engineering Laboratory
}

This publication is available free of charge from:

https://doi.org/10.6028/NIST.TN.2101

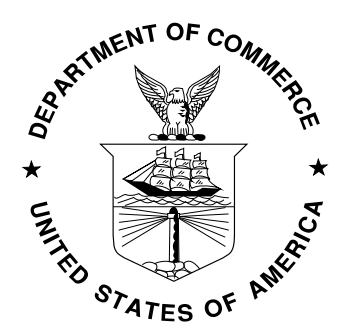

U.S. Department of Commerce

Wilbur L. Ross, Jr., Secretary

National Institute of Standards and Technology Walter Copan, NIST Director and Undersecretary of Commerce for Standards and Technology 
Certain commercial entities, equipment, or materials may be identified in this document in order to describe an experimental procedure or concept adequately. Such identification is not intended to imply recommendation or endorsement by the National Institute of Standards and Technology, nor is it intended to imply that the entities, materials, or equipment are necessarily the best available for the purpose.

National Institute of Standards and Technology Technical Note 2101

Natl. Inst. Stand. Technol. Tech. Note 2101, 51 pages (July 2020)

CODEN: NTNOEF

This publication is available free of charge from: https://doi.org/10.6028/NIST.TN.2101 


\begin{abstract}
Two air-source, split system heat pumps were installed in a residential, net-zero energy home that was constructed as a laboratory on the campus of the National Institute of Standards and Technology (NIST) in Gaithersburg, Maryland USA. The first heat pump was a two-stage, $7 \mathrm{~kW}$ (2 ton), 15.8 seasonal energy efficiency ratio (SEER), 9.05 heating seasonal performance ratio (HSPF) conventionally ducted system, and the second heat pump was a variable-speed, $10.6 \mathrm{~kW}$ (3 ton), 14 SEER, 8.35 HSPF, high velocity ducted system. These two systems operated side-by-side, using separate supply ducts and a common return duct, on a weekly alternating schedule to condition the home that was operated with very consistent, simulated thermal loads. We wanted to know if the high velocity system could provide comparable energy use efficiency to the conventional system. The results of this study showed that it did meet the required loads while doing so with slightly greater efficiency; the average cooling coefficient of performance (COP) was $(0.40 \pm 0.11)$ higher, and the average heating COP was statistically equal. A new firmware was provided at the end of the heating season which greatly improved the performance of the high velocity system; its average heating COP went from $(1.8 \pm 0.9)$ to $(2.5 \pm 1.1)$ at a $95 \%$ confidence level. The new firmware heating COP averaged $(1.05 \pm 0.23)$ higher than the old firmware over the same outdoor temperatures. Defrost performance is very different for these two systems yet they consumed equivalent energy per HDD; the conventional system uses a timed-initiate, temperature-terminate algorithm with auxiliary electric resistive heating while the high velocity system uses calculated evaporator parameters with a hot-gas bypass before a full reverse cycle defrost with no supplementary resistive heat.
\end{abstract}

\title{
Key words
}

energy use comparison; field test; low load home; net-zero home; small duct high velocity; two-stage heat pump; variable-speed heat pump 


\section{Table of Contents}

1. INTRODUCTION .............................................................................................................. 1

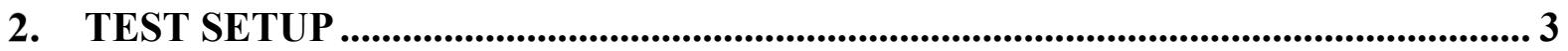

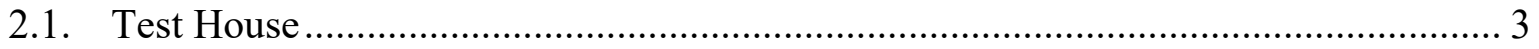

2.2. Air Duct Systems for the Heat Pumps...................................................................... 4

2.3. Tested Heat Pumps and Measurement Uncertainty ..................................................... 4

3. RESULTS ......................................................................................................................... 9

3.1. Cooling Season....................................................................................... 10

3.1.1. Cooling Energy ......................................................................................... 11

3.1.2. Cooling Standby Energy Use ………………................................................. 17

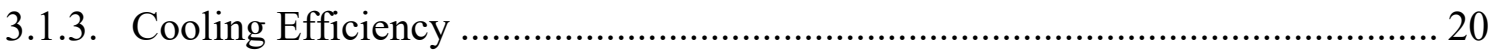

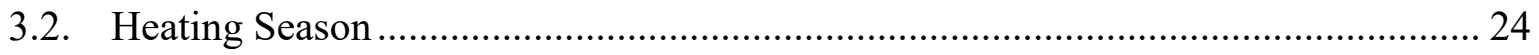

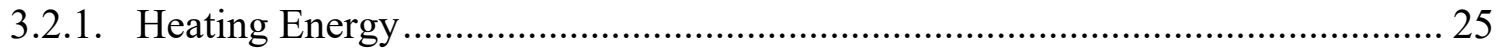

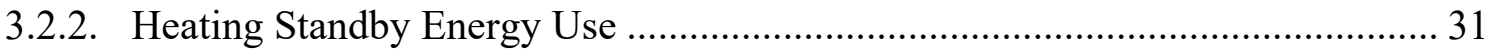

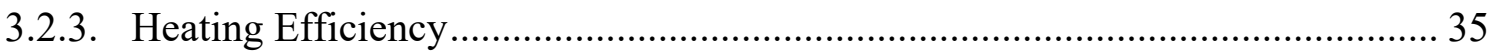

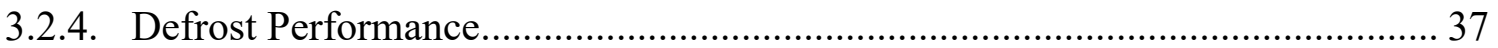

4. CONCLUSIONS AND RECOMMENDATIONS ......................................................... 41

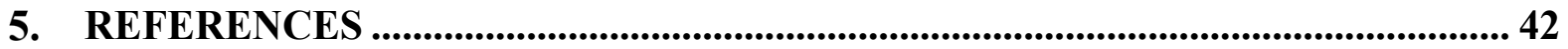

\section{List of Tables}

Table 1: Rated performance of the two heat pump systems ……….................................... 5

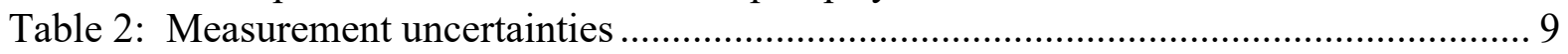

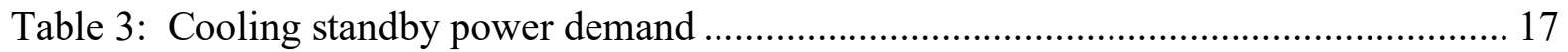

\section{List of Figures}

Figure 1: NIST Net-Zero Residential Test Facility (NZERTF), A) left front at ground level and B) right front elevated view ................................................................................... 2

Figure 2: Thermostat locations, a) wide view and b) detailed view ....................................... 4 Figure 3: Measurement points for a) Conventional ducted, two-stage heat pump, b) Small duct high velocity, variable-speed heat pump.................................................................... 7 Figure 4: CDHP system indoor and outdoor units at the NZERTF, a) indoor air handler and

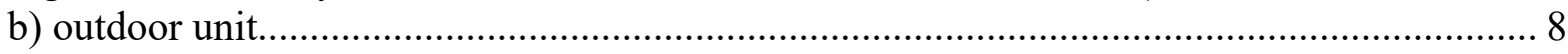
Figure 5: SDHV system indoor and outdoor units at the NZERTF, a) indoor air handler and

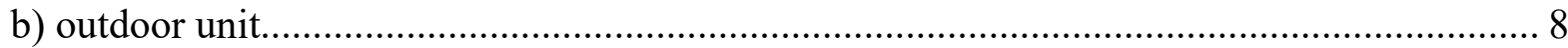

Figure 6: Cooling degree days seen by both systems ......................................................... 10

Figure 7: Cooling electrical energy use for the entire cooling season.................................. 11

Figure 8: Cooling season electrical energy usage ................................................................. 12

Figure 9: Cooling season thermal energy ……………................................................... 12 
Figure 10: Cooling daily average operating airflow rates as a function of CDD ................. 13

Figure 11: Cooling daily average indoor blower efficacy (W/(unit volume flow)) .............. 14 Figure 12: Daily cooling air circulation ratio (number of whole house air volume air-changes

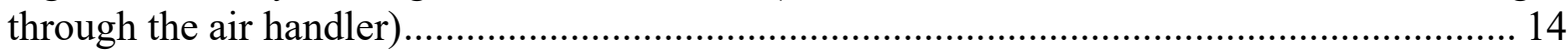

Figure 13: Cooling daily system percent duty .............................................................. 15

Figure 14: Cooling average operating supply air temperatures .......................................... 16

Figure 15: Cooling average operating indoor unit air temperature change ........................... 16

Figure 16: Cooling daily average operating return air temperatures ................................... 17

Figure 17: Low voltage transformers in the two systems, a) CDHP E-core laminated plate

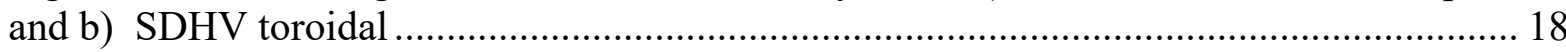

Figure 18: Cooling indoor unit daily standby energy use ....................................................... 18

Figure 19: Cooling outdoor unit daily standby energy use................................................. 19

Figure 20: Cooling system daily total standby energy use ................................................... 19

Figure 21: Cooling season coefficient of performance (COP) ............................................... 21

Figure 22: Cooling suction refrigerant saturation temperature example ............................... 21

Figure 23: Cooling discharge refrigerant saturation temperature example ............................ 22

Figure 24: Cooling temperature lift example.................................................................... 22

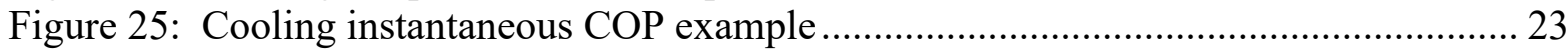

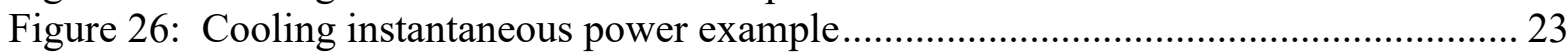

Figure 27: Cooling instantaneous capacity example ...................................................... 24

Figure 28: Cooling COP as a function of daily average outdoor temperature........................ 24

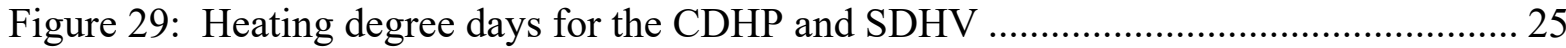

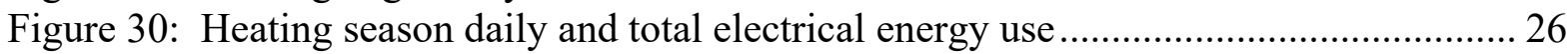

Figure 31: Heating season electrical energy use as a function of HDD's ............................... 27

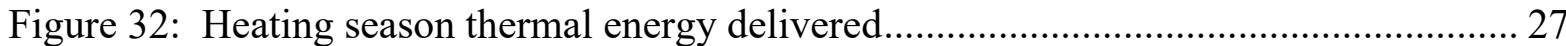

Figure 33: Heating daily average operating airflow rates...................................................... 28

Figure 34: Heating average indoor blower efficacy (W/(unit volume flow))......................... 29

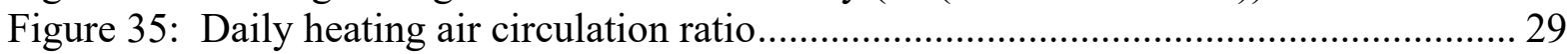

Figure 36: Heating daily system percent duty .................................................................... 30

Figure 37: Heating average operating supply air temperatures ........................................... 30

Figure 38: Heating average operating indoor unit air temperature change ............................ 31

Figure 39: Heating daily average operating return air temperature ...................................... 31

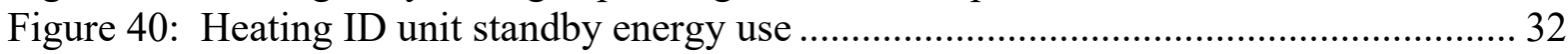

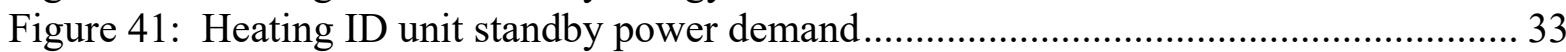

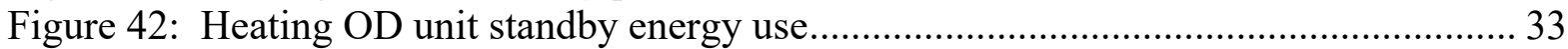

Figure 43: Heating OD unit standby power demand ............................................................ 34

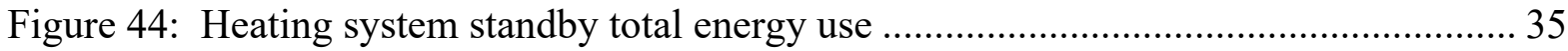

Figure 45: Heating COP versus HDD with original and new firmware ................................. 36

Figure 46: Heating supply air temperatures with original and new firmware ........................ 36

Figure 47: Heating COP as a function of daily average outdoor air temperature................... 37

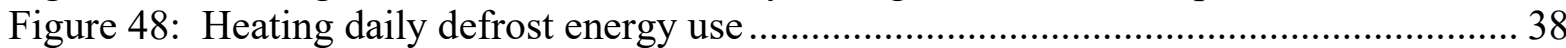

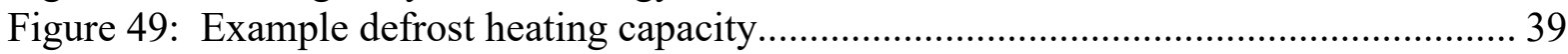

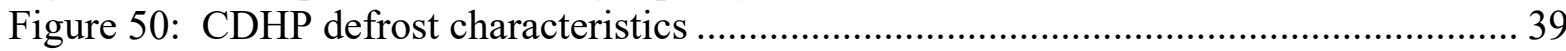

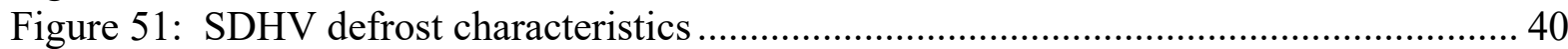

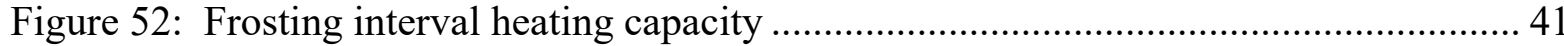




\section{NOMENCLATURE}

\begin{tabular}{|c|c|c|c|}
\hline CDD & cooling degree day & ID & indoor \\
\hline CDHP & conventionally ducted heat & OD & outdoor \\
\hline $\mathrm{cfm}$ & $\begin{array}{l}\text { pump } \\
\text { cubic feet per minute }\end{array}$ & NZERTF & $\begin{array}{l}\text { net-zero energy residential test } \\
\text { facility }\end{array}$ \\
\hline $\mathrm{COP}$ & coefficient of performance & SDHV & small duct high velocity heat \\
\hline Conv. & conventior & & pump \\
\hline EER & energy efficiency ratio & SEER & seasonal energy efficiency \\
\hline ESP & al static pressure & & \\
\hline HDD & heating degree day & $T_{\mathrm{ID}}$ & indoor dry-bulb ter \\
\hline HSPF & $\begin{array}{l}\text { heating seasonal performance } \\
\text { factor }\end{array}$ & $\begin{array}{l}T_{\mathrm{OD}} \\
\text { wrt }\end{array}$ & $\begin{array}{l}\text { outdoor dry-bulb temperature } \\
\text { with respect to }\end{array}$ \\
\hline
\end{tabular}




\section{INTRODUCTION}

The residential style net-zero home on the main campus of the National Institute of Standards and Technology offers a unique test bed for residential air-conditioning technologies; within the home, we can install several air-conditioning systems in parallel so that operation of the selected system can occur at nearly the same weather conditions and load profile. With this in mind, we installed a small duct high velocity heat pump (HP) in parallel with a conventionally ducted air-source heat pump to answer the following question: Can a small duct high velocity HP system, whose ductwork is much easier to install than a conventional duct system, provide comparable energy-use efficiency? The two systems were installed side-by-side in the house with one system operating for a week and the other system operating for a week in an alternating fashion for a whole cooling and heating season. The main parameters that could answer our question were measured on both systems; namely, electrical energy use and cooling/heating thermal energy. Human comfort performance of the two systems is described in a complementary publication by Kim et al. (2019).

A more complete description of the net-zero home may be found in Fanney et. al (2015). The net-zero house (Fig. 1) includes a detached two-car garage. It is a two-story, three- to fourbedroom house with three full bathrooms and is separated from the garage by a breezeway. The first floor includes a utility closet for the clothes washer, dryer and a future multi-split heat pump indoor unit, the kitchen and dining area, a family room, an office (optional bedroom), a full bathroom, and an open foyer to the second floor. The second floor consists of a master bedroom with adjoining bathroom, two additional bedrooms, a second bath, and a hallway. The house includes a full $135 \mathrm{~m}^{2}\left(1435 \mathrm{ft}^{2}\right)$ basement. The detached garage contains the data acquisition/control equipment associated with the facility. The front of the house faces true south and accommodates two solar systems; a $10.2 \mathrm{~kW}$ photovoltaic system located on the main roof and four $2.2 \mathrm{~m}^{2}\left(24 \mathrm{ft}^{2}\right)$ solar thermal collectors on the roof of the front porch.

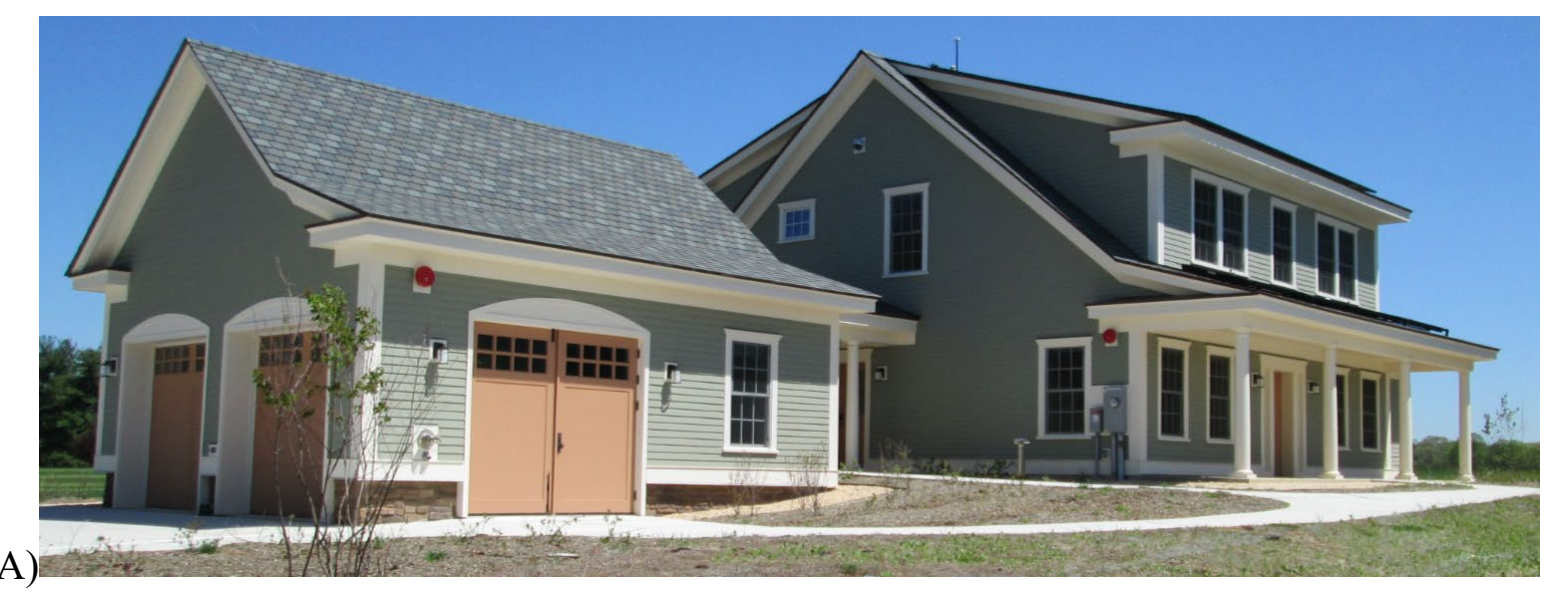




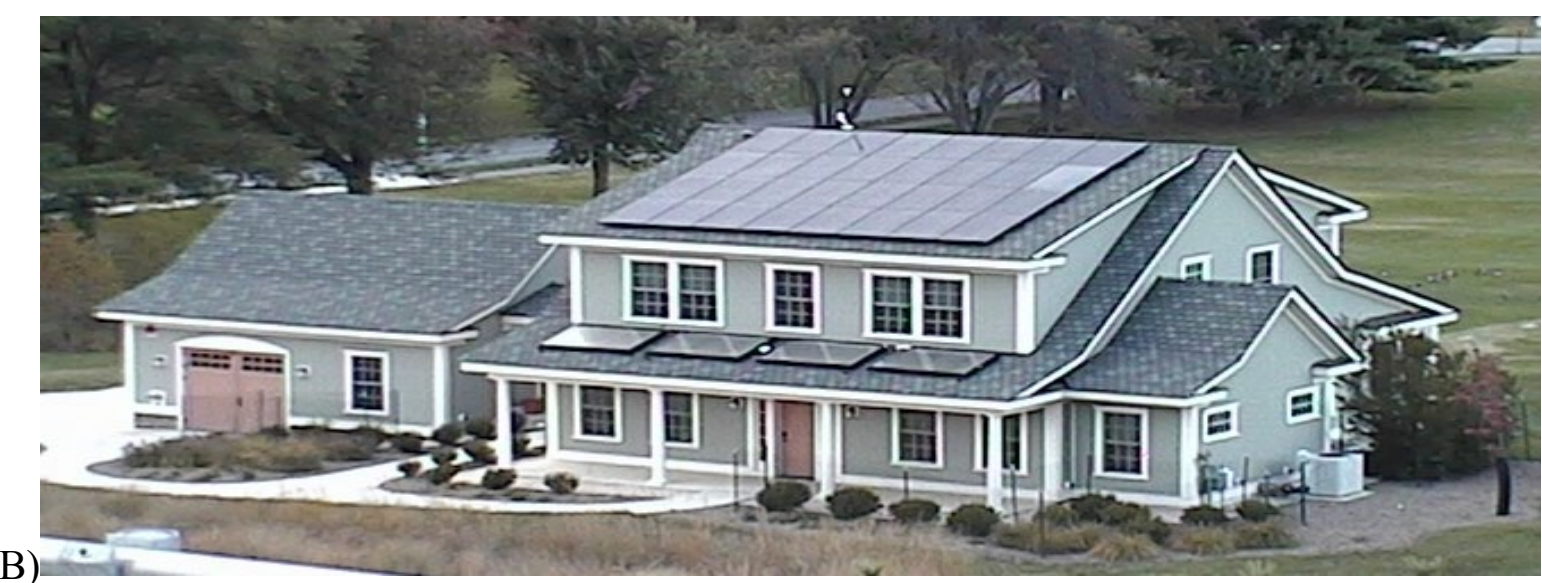

Figure 1: NIST Net-Zero Residential Test Facility (NZERTF), A) left front at ground level and $\mathrm{B}$ ) right front elevated view

Due to the air tightness of the home, the house is mechanically ventilated according to ASHRAE Std. 62.2 (2010). The NZERTF uses a heat recovery ventilator to provide outdoor air to all the bedrooms. The ventilator operates to deliver $136 \mathrm{~m}^{3} \mathrm{~h}^{-1}(80 \mathrm{cfm})$ for 45 minutes of every hour. This system operates independently of the HVAC systems and has a separate duct system.

Many investigations have been performed to examine the performance of various HVAC systems in low load homes. The largest body of work has been performed by the national labs funded by the U.S. Department of Energy's Building America Program (2019).

Poerscke and Rudd (2016) studied the efficacy of using small duct airflow distribution systems in several different homerun configurations. Their goal was to optimize air distribution and minimize temperature differences in the test homes. They showed that this could be done with their central manifold systems while maintaining air distribution energy efficiencies between 0.16 and $0.22 \mathrm{~W} \mathrm{cfm}^{-1}$. They attempted to design air distribution manifolds and small duct (PVC pipe) combinations that allowed for a better balance when changes were made to a particular run. This work could provide good data for a training data set in many multi-factor optimization algorithms.

Duct design methods should change to reflect the operating regimes of multi-speed and variable speed equipment. The ducting should be designed to optimize the lifetime performance of the system; this means the ducting should give the best performance for the most likely static pressures (air flow rates) that will occur. Duct design tools should incorporate more detailed load information along with weather data files and operational models to produce a ducting system optimized for lowest lifetime air moving cost to the consumer. This is a complicated, multi-objective optimization problem, that has been examined by many researchers [(Besant and Asiedu 2000), (Tsal et al. 1998), (Caldas and Norford 2013), (Jorens et al. 2018)]. Residential duct designers need a product that can be used by non-expert practitioners to design residential duct systems for lowest lifetime cost.

Martin et al. (2018) performed testing on the same small duct, high velocity (SDHV) system as installed in the NZERTF. They examined the energy use and dehumidification performance of the SDHV in a hot-humid climate (Zone 2a). Their design cooling load was only $13 \%$ greater than that of the NZERTF. The 14 SEER, variable-speed, SDHV system used $8.2 \%$ 
less energy in the cooling season than a 13 SEER single-speed system and $16.7 \%$ more energy than a 22 SEER, variable-capacity system, but the SDHV system maintained lower humidity levels overall than the other systems.

\section{TEST SETUP}

\subsection{Test House}

The first and second floors have a combined living area of $252 \mathrm{~m}^{2}\left(2713 \mathrm{ft}^{2}\right)$. Including the basement (actively conditioned) and attic (passively conditioned), the total floor space is $425 \mathrm{~m}^{2}\left(4578 \mathrm{ft}^{2}\right)$. The building has a total conditioned volume of $1268 \mathrm{~m}^{3}\left(44773 \mathrm{ft}^{3}\right)$ which includes the attic and basement spaces. Window to wall area ratio for the 1st floor North, South, East and West sides are 0.167, 0.201, 0.143 and 0.048; the $2^{\text {nd }}$ floor, in the same order, is $0.123,0.285,0.050$ and 0.050 . The outside perimeter length of the basement and $1^{\text {st }}$ floor is $47.155 \mathrm{~m}(154 \mathrm{ft}, 8.5 \mathrm{in})$, and the $2^{\text {nd }}$ floor is $42.418 \mathrm{~m}$ (139 ft, $\left.2 \mathrm{in}\right)$. The building envelope was constructed using a continuous air barrier system to minimize infiltration with building ventilation provided by a heat recovery ventilation (HRV) system. Five blower door tests were conducted at various stages of construction, with the final test, conducted after the house was complete, yielding an air exchange rate of $802 \mathrm{~m}^{3} \mathrm{~h}^{-1}(1200 \mathrm{cfm})$ at $50 \mathrm{~Pa}(0.2 \mathrm{in} \mathrm{wg})$ corresponding to 0.63 air changes per hour $(\mathrm{ACH})$. Details can be found in Fanney et al. (2015). A detailed TRNSYS model of the house was developed by Balke et al. (2018).

The house is in U.S. Department of Energy (DOE) climate zone 4A. This climate zone is defined as Mixed Humid with IP Units CDD50 ${ }^{\circ} \mathrm{F} \leq 4500$ and $3600<\mathrm{HDD} 65^{\circ} \mathrm{F} \leq 5400$ and SI Units $\mathrm{CDD} 10^{\circ} \mathrm{C} \leq 2500$ and $\mathrm{HDD} 18^{\circ} \mathrm{C} \leq 3000$. The house design cooling and heating thermal loads are $4722 \mathrm{~W}\left(16114 \mathrm{Btuh}^{-1}\right)$ and $5667 \mathrm{~W}\left(19336 \mathrm{Btuh}^{-1}\right)$. This is equivalent to $11.11 \mathrm{Wm}^{-2}$ and $13.33 \mathrm{Wm}^{-2}$ at design day cooling and heating temperatures of $32.8^{\circ} \mathrm{C}\left(91{ }^{\circ} \mathrm{F}\right)$ and $-8.9^{\circ} \mathrm{C}\left(16^{\circ} \mathrm{F}\right)$.

The heat pumps were controlled by wall mounted thermostats that measured temperature in the living room and dining room area (Fig. 2). These were the only thermostats used so all operations were as if the house were a single zone. Cooling season setpoint temperature was $23.8^{\circ} \mathrm{C}\left(75^{\circ} \mathrm{F}\right)$ and heating season setpoint was $21.1^{\circ} \mathrm{C}\left(70^{\circ} \mathrm{F}\right)$. 


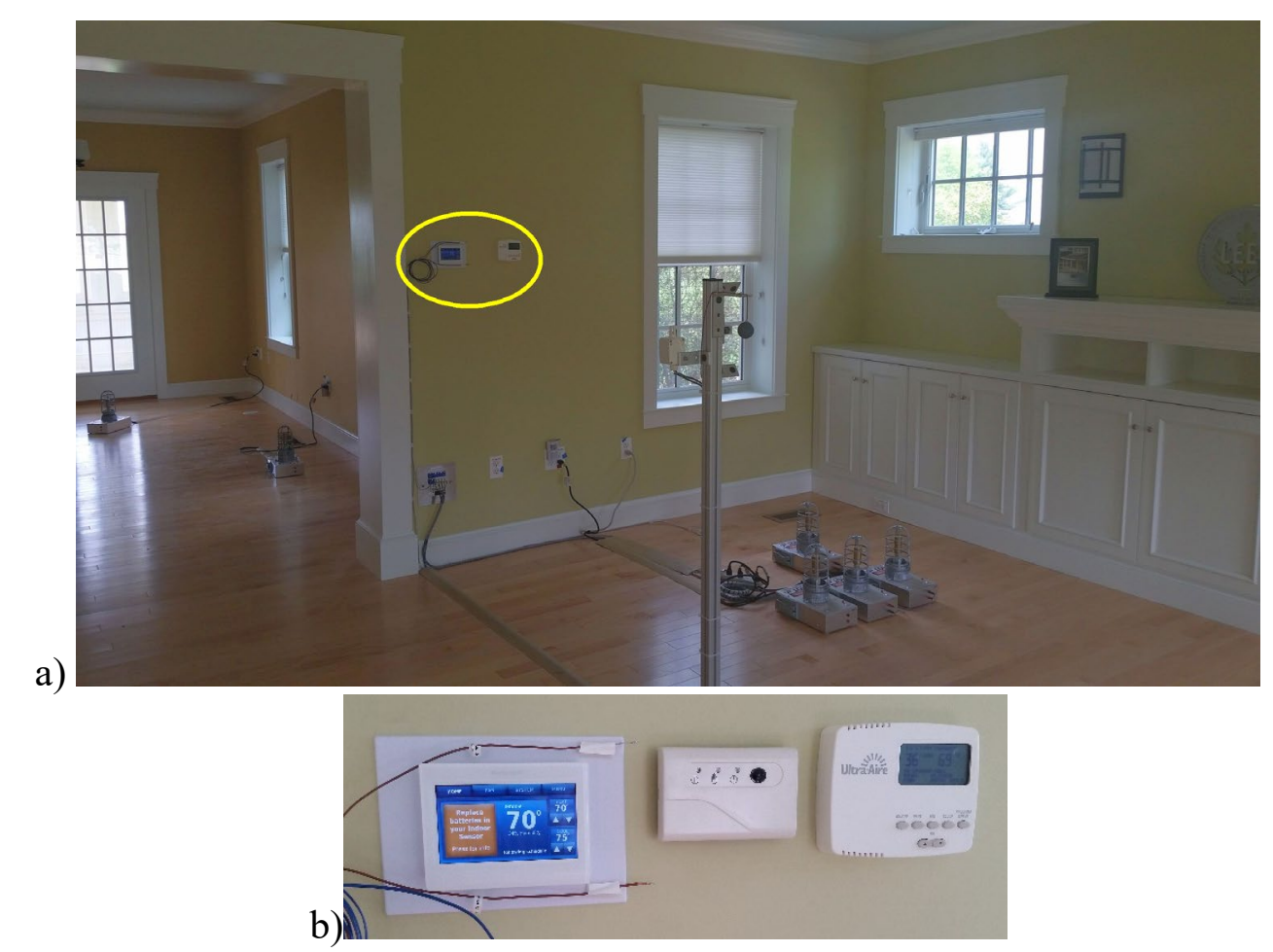

Figure 2: Thermostat locations, a) wide view and b) detailed view

\subsection{Air Duct Systems for the Heat Pumps}

The NZERTF has four separate air duct systems; 1) a conventional duct system utilized with air-to-air or ground-source heat pumps; 2) a small duct, high velocity (SDHV) air distribution system used in conjunction with an air-to-air SDHV heat pump; 3) a dedicated duct system associated with the heat recovery ventilator; and 4) a short run supply air duct system on the first and second floors for two ceiling mounted cassette-type mini air handlers used with multisplit, variable-speed, air-source heat pumps. All four duct systems are within conditioned spaces. Further discussions will focus upon the conventional and high velocity duct systems.

The conventional duct system was designed for less than $124.5 \mathrm{~Pa}(0.5 \mathrm{in} \mathrm{wg})$ static pressure drop at supply and return duct air flow rates of $2039 \mathrm{~m}^{3} \mathrm{~h}^{-1}(1200 \mathrm{cfm})$ with all air supplies fully open. The insulated main trunk lines are located with the air handler in the basement. Multiple supply registers are in each room of the house. Return ducts are in central locations on the first and second floors.

The small duct high velocity air distribution system begins in the basement with an insulated main trunk line that rings the basement perimeter allowing takeoffs for individual room air supply registers that supply the first floor. A large, insulated, supply riser feeds a similar ring in the attic. The trunk lines are $22.9 \mathrm{~cm}(9 \mathrm{in})$ in diameter and designed for an air flow rate of $2039 \mathrm{~m}^{3} \mathrm{~h}^{-1}(1200 \mathrm{cfm})$. The takeoff ducts that supply the individual registers are $6.35 \mathrm{~cm}$ (2.5 in) in diameter.

\subsection{Tested Heat Pumps and Measurement Uncertainty}

The rated cooling and heating performance of the two heat pump systems at AHRI Standard $210 / 240$ conditions (2017) is shown below in Table 1 . The calculated loads and duct layout were determined by the original architectural firm using a computer program that utilized 
ACCA Manual J (2012a) and ACCA Manual D (2012b). Oversizing of variable speed equipment allows the equipment to operate at part load for the majority of its runtime and thus operate at higher efficiency. A thorough discussion of selecting variable speed equipment based on efficiency and the implications for human comfort can be found in Cummings and Withers (2014) and Shirey et al. (2006).

Table 1: Rated performance of the two heat pump systems

\begin{tabular}{|c|c|c|c|c|c|}
\hline System & $\begin{array}{c}\text { SEER } \\
{\left[\mathrm{Btu}(\mathrm{Wh})^{-1}\right]}\end{array}$ & $\begin{array}{c}\text { EER Cooling } \\
{\left[\mathrm{Btu}(\mathrm{Wh})^{-1}\right]}\end{array}$ & $\begin{array}{c}\text { HSPF } \\
\text { Region IV } \\
{\left[\mathrm{Btu}(\mathrm{Wh})^{-1}\right]}\end{array}$ & $\begin{array}{c}\text { Cooling } \\
\text { Capacity, W } \\
{\left[\mathrm{Btu} \mathrm{h}^{-1}\right]}\end{array}$ & $\begin{array}{c}\text { Heating } \\
\text { Capacity, W } \\
{\left[\mathrm{Btu} \mathrm{h}^{-1}\right]}\end{array}$ \\
\hline $\begin{array}{c}\text { Conventional } \\
\text { (Two-Stage) }\end{array}$ & 15.80 & 13.05 & 9.05 & $7620[26000]$ & $7796[26600]$ \\
\hline $\begin{array}{c}\text { SDHV } \\
\text { (Variable- } \\
\text { Speed) }\end{array}$ & 14.00 & 7.45 & 8.35 & $8558[29200]$ & $\begin{array}{c}10317 \\
{[35200]}\end{array}$ \\
\hline $\begin{array}{c}\text { Calculated } \\
\text { LOADS }\end{array}$ & & & & $4723[16114]$ & $5667[19336]$ \\
\hline
\end{tabular}

Both systems were fully instrumented and connected to data acquisition devices that monitored them continuously; 10 second scans during the off-period and 3 second scans during the onperiod. The data were saved and aggregated for each day of testing. Figure 3 shows the measured points for each of the systems. Figure 4 shows the conventionally ducted heat pump (CDHP) system and Fig. 5 shows the SDHV system at their installed locations in the NZERTF. 


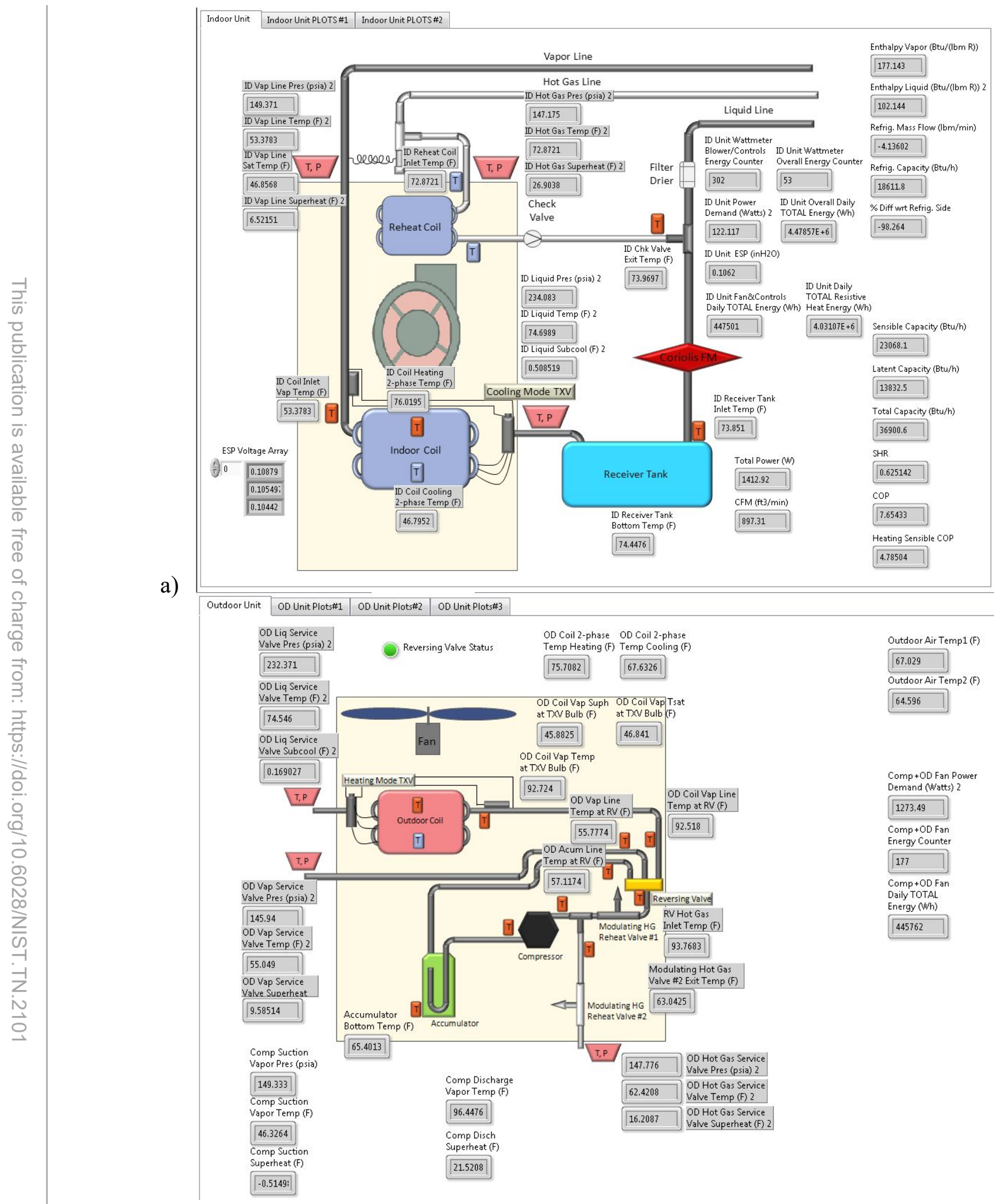




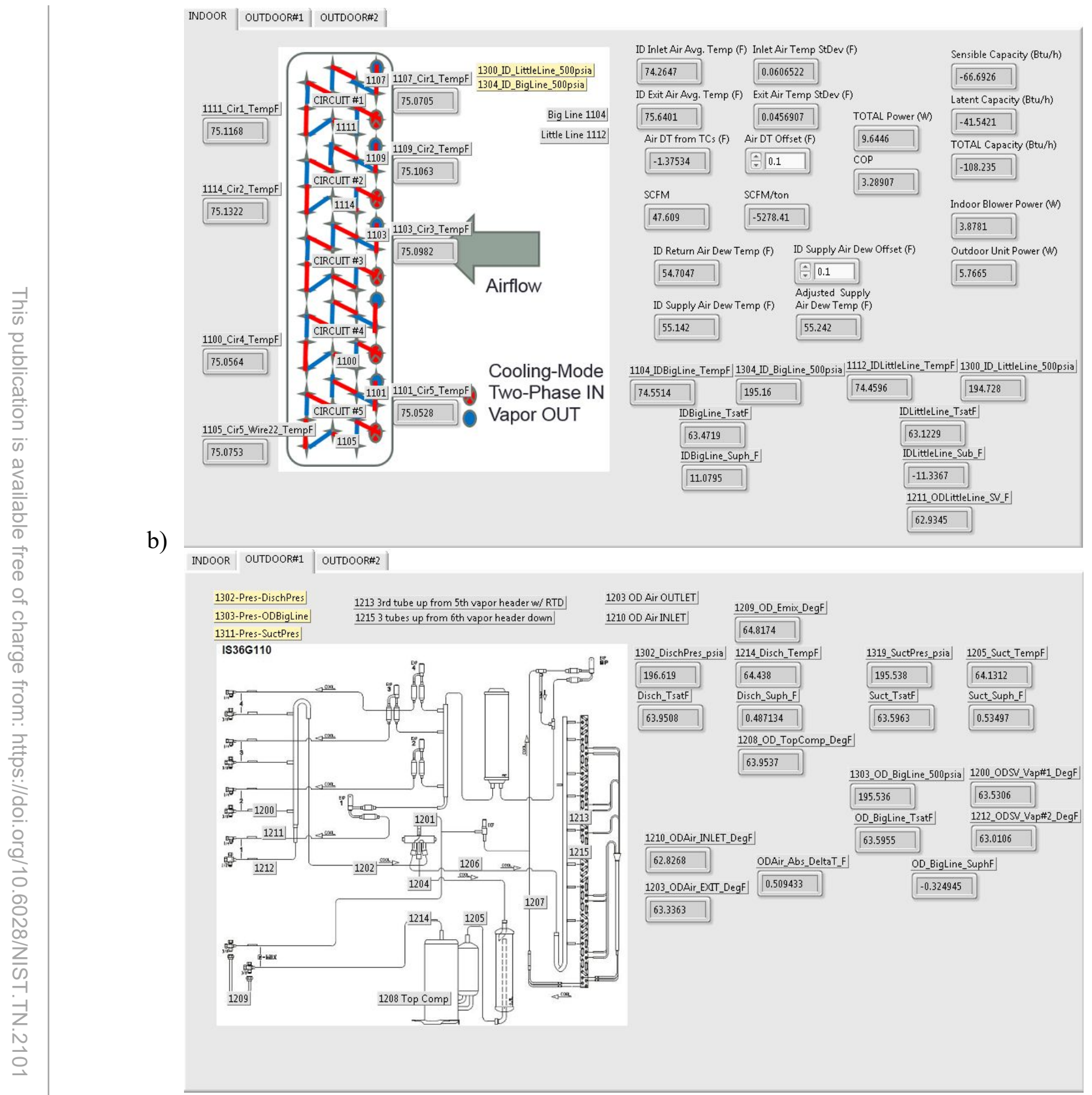

Figure 3: Measurement points for a) Conventional ducted, two-stage heat pump, b) Small duct high velocity, variable-speed heat pump 

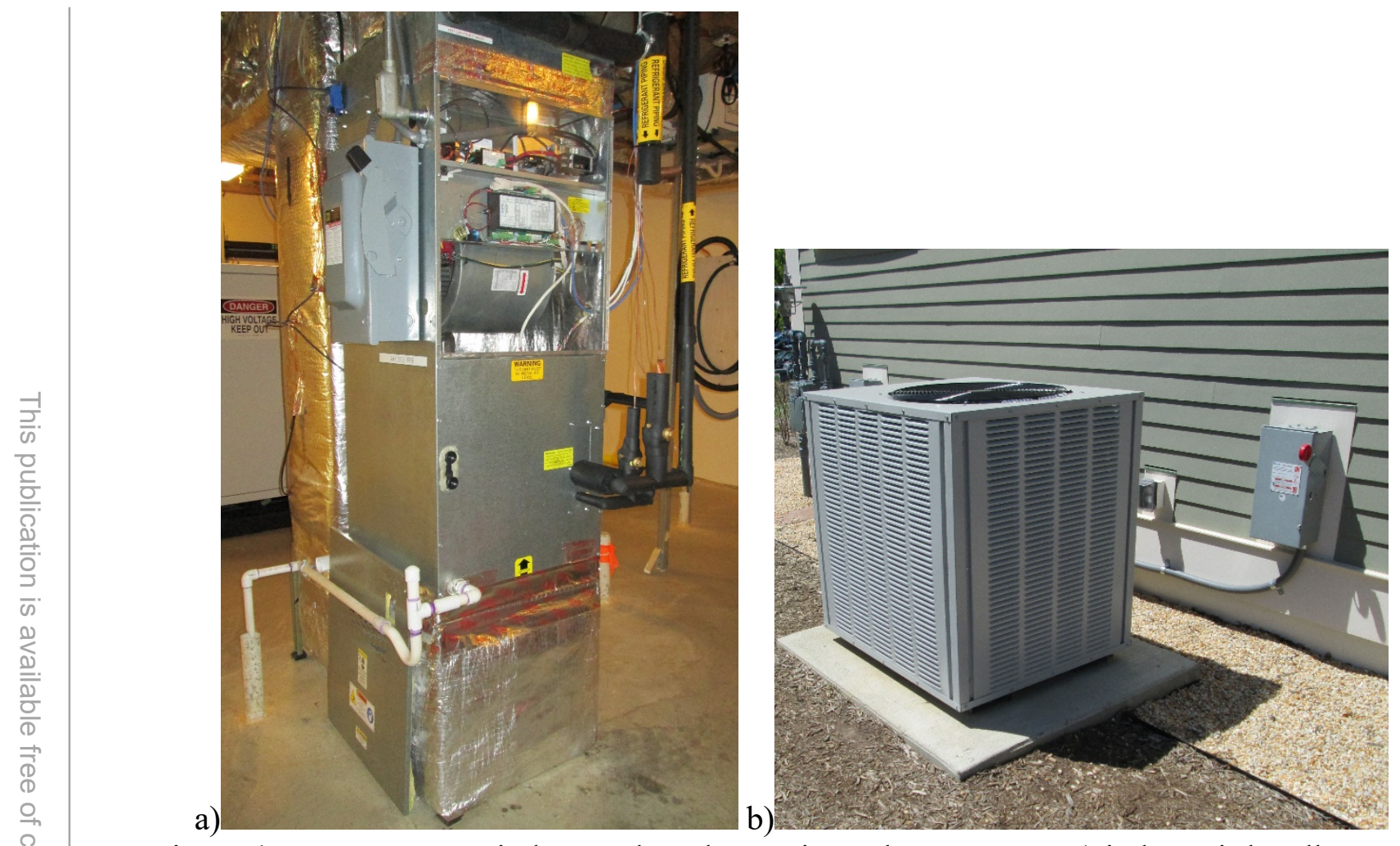

Figure 4: CDHP system indoor and outdoor units at the NZERTF, a) indoor air handler and b) outdoor unit
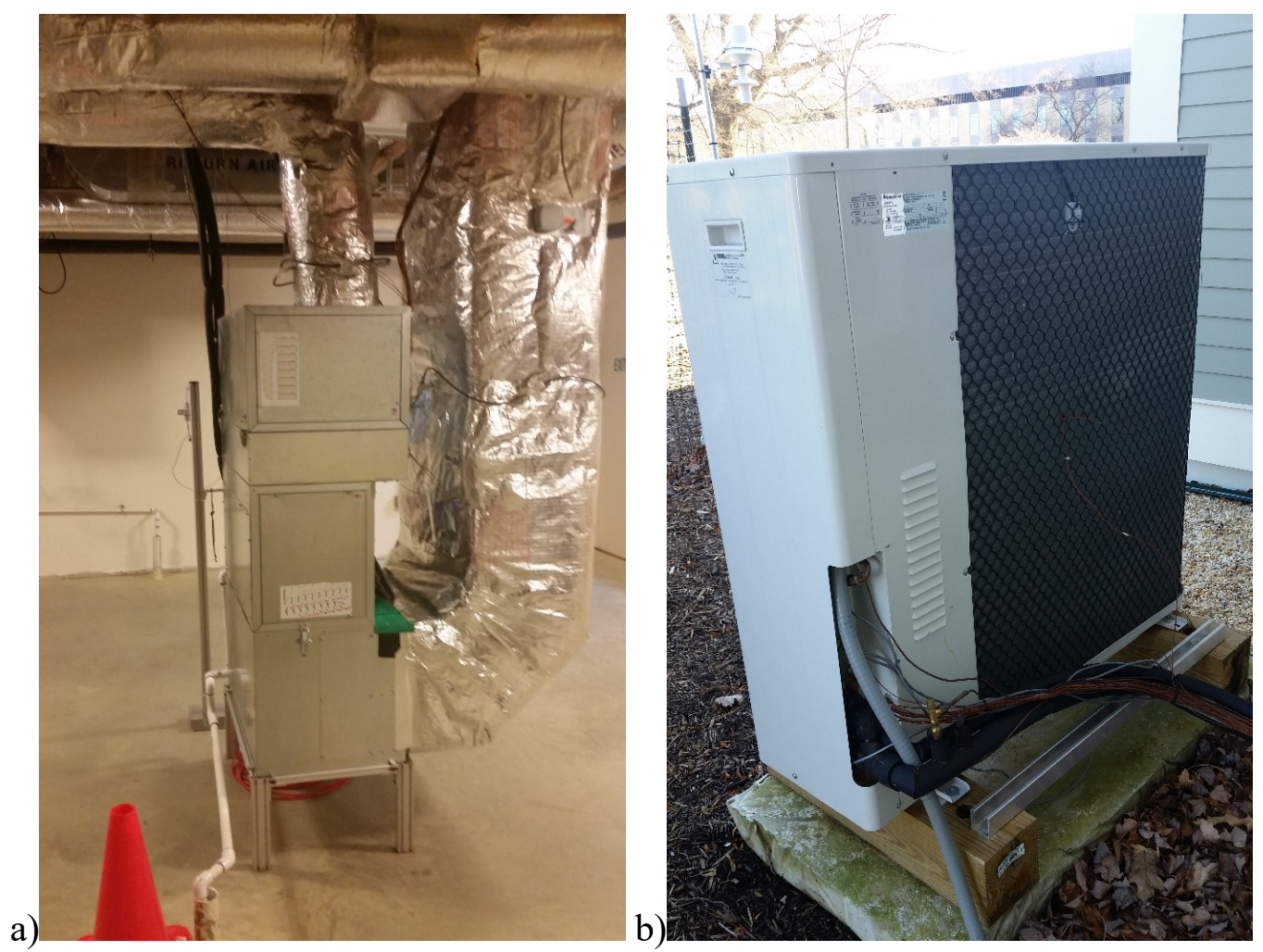

Figure 5: SDHV system indoor and outdoor units at the NZERTF, a) indoor air handler and b) outdoor unit 
Table 2 lists the measurement uncertainties for both systems at a $95 \%$ confidence level. A detailed uncertainty analysis was performed in Davis et al. (2014). The plus or minus uncertainties included with measured quantities are calculated as two standard deviations of multiple measurements. The uncertainty of values calculated from a least squares fit is listed as twice the fit standard error $(\mathrm{k}=2$ coverage factor) unless stated otherwise.

Table 2: Measurement uncertainties

\begin{tabular}{|c|c|c|}
\hline Instrument & Range & $\begin{array}{c}\text { Total Uncertainty at a } \\
95 \% \text { Confidence } \\
\text { Level }\end{array}$ \\
\hline T-type thermocouples & $\begin{array}{l}-10^{\circ} \mathrm{C} \text { to } 55^{\circ} \mathrm{C} \\
\left(16^{\circ} \mathrm{F} \text { to } 131^{\circ} \mathrm{F}\right)\end{array}$ & $\pm 0.6^{\circ} \mathrm{C}\left(1.0^{\circ} \mathrm{F}\right)$ \\
\hline $\begin{array}{l}\text { High pressure } \\
\text { transducer }\end{array}$ & $6895 \mathrm{kPa}(1000$ psig) & $\pm 0.25 \%$ of reading \\
\hline $\begin{array}{l}\text { Low pressure } \\
\text { transducer }\end{array}$ & $3447 \mathrm{kPa}$ (500 psig) & $\pm 0.25 \%$ of reading \\
\hline $\begin{array}{c}\text { Air pressure } \\
\text { differential }\left(\mathrm{ESP}^{1}\right)\end{array}$ & $\begin{array}{c}0 \text { to } 187 \mathrm{~Pa} \\
\left(0 \text { to } 0.75 \text { in } \mathrm{H}_{2} \mathrm{O}\right)\end{array}$ & $\pm 0.8 \%$ of reading \\
\hline $\begin{array}{l}\text { Indoor blower and } \\
\text { controls power meter }\end{array}$ & 0 to $300 \mathrm{VAC}, 5$ Amps, $1000 \mathrm{~W}$ & $\pm 5 \mathrm{~W}$ \\
\hline $\begin{array}{l}\text { Indoor total power } \\
\text { meter }\end{array}$ & 0 to $300 \mathrm{VAC}, 100 \mathrm{Amps}, 20000 \mathrm{~W}$ & $\pm 100 \mathrm{~W}$ \\
\hline $\begin{array}{l}\text { Outdoor unit power } \\
\text { meter }\end{array}$ & 0 to $300 \mathrm{VAC}, 20 \mathrm{Amps}, 4000 \mathrm{~W}$ & $\pm 20 \mathrm{~W}$ \\
\hline $\begin{array}{l}\text { Supply air dewpoint } \\
\text { temperature sensor }\end{array}$ & $\begin{array}{l}-28.8^{\circ} \mathrm{C} \text { to } 49^{\circ} \mathrm{C} \\
\left(-20^{\circ} \mathrm{F} \text { to } 120^{\circ} \mathrm{F}\right)\end{array}$ & $\pm 1.0^{\circ} \mathrm{C}\left(1.8^{\circ} \mathrm{F}\right)$ \\
\hline $\begin{array}{c}\text { Coriolis refrigerant } \\
\text { mass flow meter on } \\
\text { CDHP }\end{array}$ & $\begin{array}{l}0 \text { to } 2180 \mathrm{~kg} \mathrm{~h}^{-1} \\
\left(0 \text { to } 80 \mathrm{lb} \mathrm{min}^{-1}\right)\end{array}$ & $\pm 0.15 \%$ of reading \\
\hline $\begin{array}{l}\text { Volumetric airflow } \\
\text { rate }\end{array}$ & $\begin{array}{l}85 \text { to } 2039 \mathrm{~m}^{3} \mathrm{~h}^{-1} \\
\text { (50 to } 1200 \mathrm{cfm} \text { ) }\end{array}$ & $5.5 \%$ of value \\
\hline Sensible capacity & $\begin{array}{c}1465 \text { to } 11137 \mathrm{~W} \\
\left(5000 \text { to } 38000 \mathrm{Btu} \mathrm{h}^{-1} \text { ) }\right.\end{array}$ & $4 \%$ to $7 \%$ \\
\hline Latent capacity & $\begin{array}{c}293 \text { to } 2931 \mathrm{~W} \\
\left(1000 \text { to } 10000 \mathrm{Btu} \mathrm{h}^{-1}\right)\end{array}$ & $25 \%$ to $40 \%$ \\
\hline Total capacity & $\begin{array}{c}2931 \text { to } 11137 \mathrm{~W} \\
\left(10000 \text { to } 38000 \mathrm{Btu} \mathrm{h}^{-1}\right)\end{array}$ & $7 \%$ to $10 \%$ \\
\hline COP & 0 to 6 & $8 \%$ to $12 \%$ \\
\hline
\end{tabular}

\section{RESULTS}

The two systems operated side-by-side with one unit operating for a week followed by the other unit operating for a week. This weekly flip-flop, instead of a daily flip-flop, was necessary because of the large thermal inertia of the net-zero house; a net-zero house can go for weeks with no space conditioning given its low losses to the environment, so a weekly flipflop was judged to be a better way to compare and remove performance overlap of the two 
systems. Cooling and heating degree days are used to normalize the results and to provide a better comparison of the heating and cooling performance of the two systems. Even though the two systems operated side-by-side in a weekly alternating pattern, weather variability prevented the two systems from having an equal number of cooling and heating degree days.

\subsection{Cooling Season}

The cooling season weather conditions seen by the two systems are characterized in Fig. 6 using Cooling Degree Days with respect to a base of $50^{\circ} \mathrm{F}\left(10^{\circ} \mathrm{C}\right)$. The conventionally ducted system experienced almost $31 \%$ more CDD's even though the two systems were alternating operations weekly.

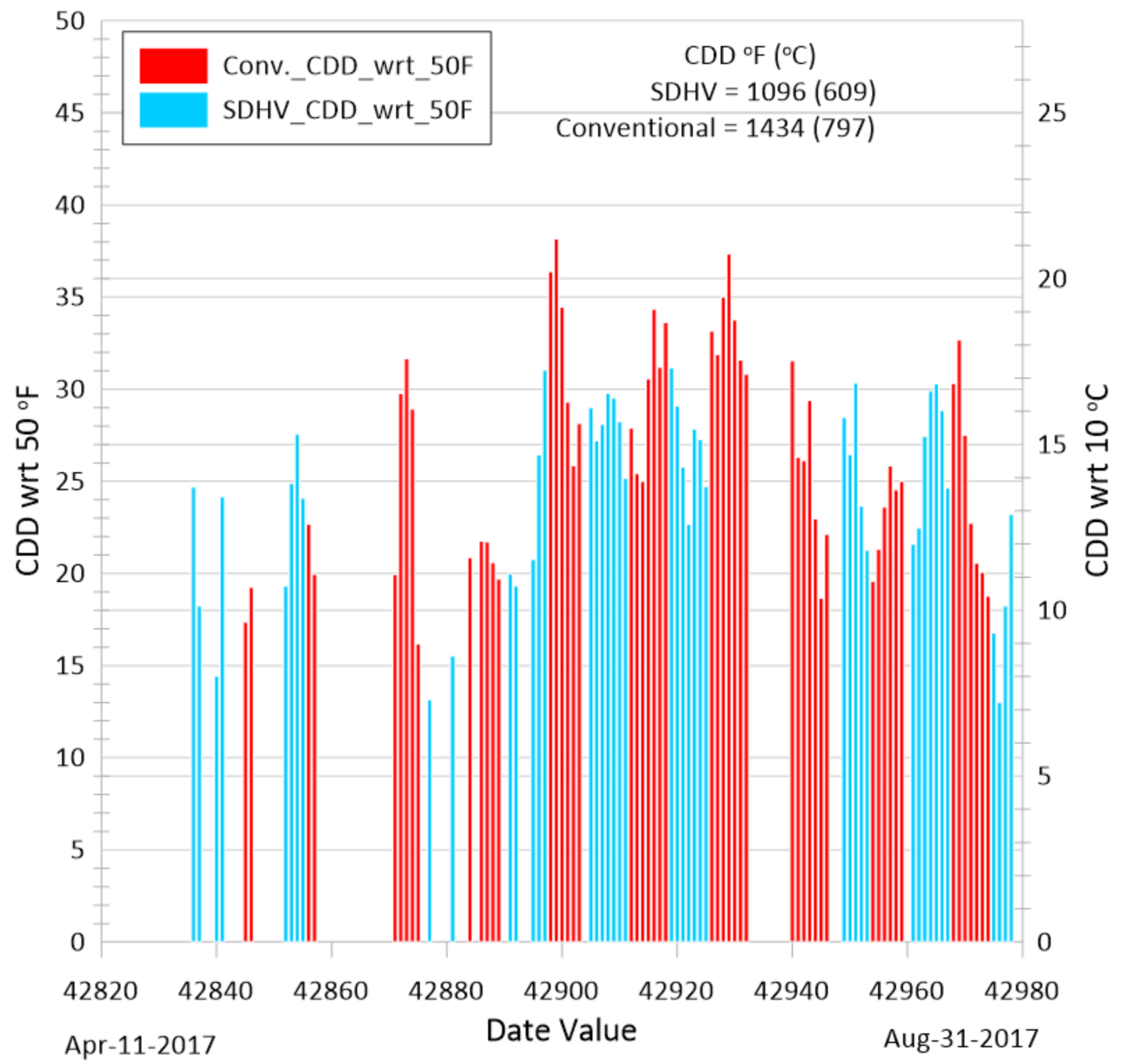

Figure 6: Cooling degree days seen by both systems 


\subsubsection{Cooling Energy}

Figure 7 shows the average daily energy usage for the two systems, along with the totals for the entire cooling season. Due to the higher number of CDD's seen by the conventional system, its energy usage was $38 \%$ greater. Figure 8 shows daily total electrical energy usage with respect to CDD's of the two systems; there is no statistical difference in their normalized average daily energy use for the cooling season at a $95 \%$ confidence level. The daily electrical energy usage per CDD for the CDHP and the SDHV were $(2.327 \pm 0.209) \mathrm{kWh}^{\circ} \mathrm{C}^{-1}$ $\left((1.293 \pm 0.116) \mathrm{kWh}^{\circ} \mathrm{F}^{-1}\right)$ and $(1.916 \pm 0.302) \mathrm{kWh}^{\circ} \mathrm{C}^{-1}\left((1.069 \pm 0.168) \mathrm{kWh}^{\circ} \mathrm{F}^{-1}\right)$, respectively. The difference in cooling season electrical energy usage per CDD was statistically insignificant; on average the SDHV system used $(282 \pm 1126)$ Wh less electrical energy per CDD. The daily thermal energy removed per CDD for the CDHP and the SDHV were $(1738 \pm 233) \mathrm{Wh}^{\circ} \mathrm{C}^{-1} \quad\left((3123 \pm 420) \mathrm{Wh}^{\circ} \mathrm{F}^{-1}\right)$ and $(2282 \pm 359) \mathrm{Wh}^{\circ} \mathrm{C}^{-1}\left((4107 \pm 647) \mathrm{Wh}^{\circ} \mathrm{F}^{-1}\right)$, respectively. The difference in cooling season thermal energy removed per CDD was statistically insignificant.

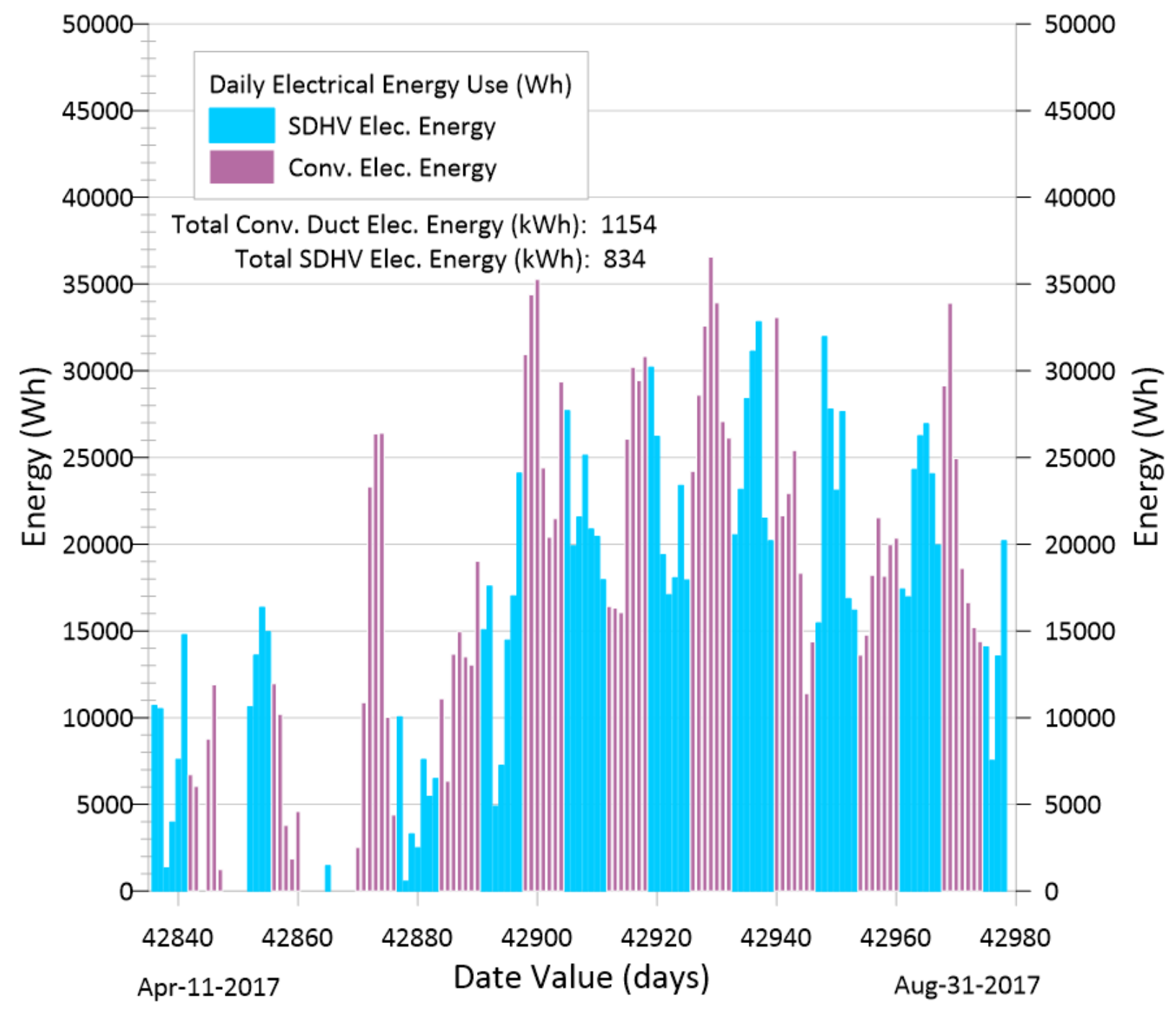

Figure 7: Cooling electrical energy use for the entire cooling season 


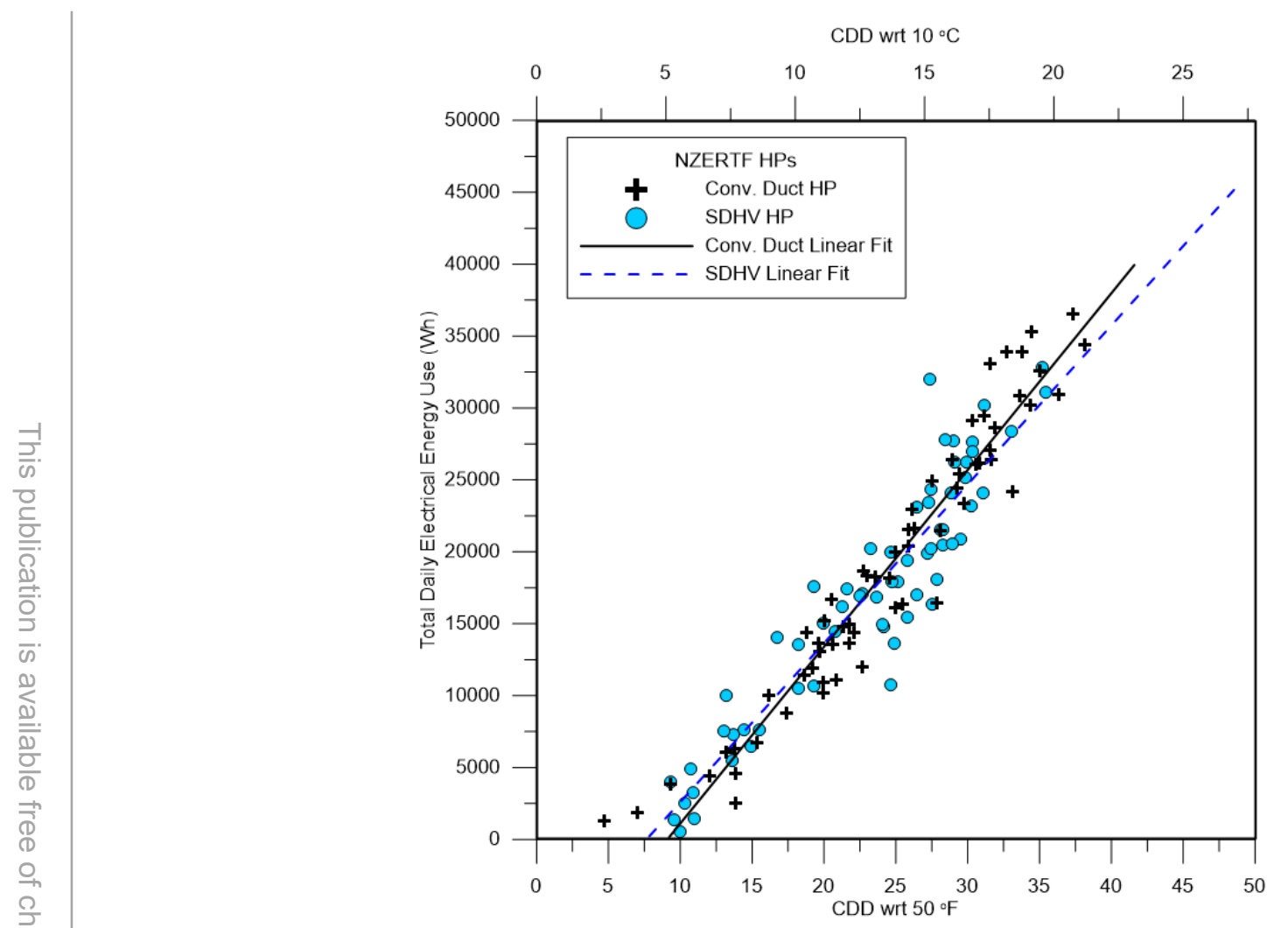

Figure 8: Cooling season electrical energy usage

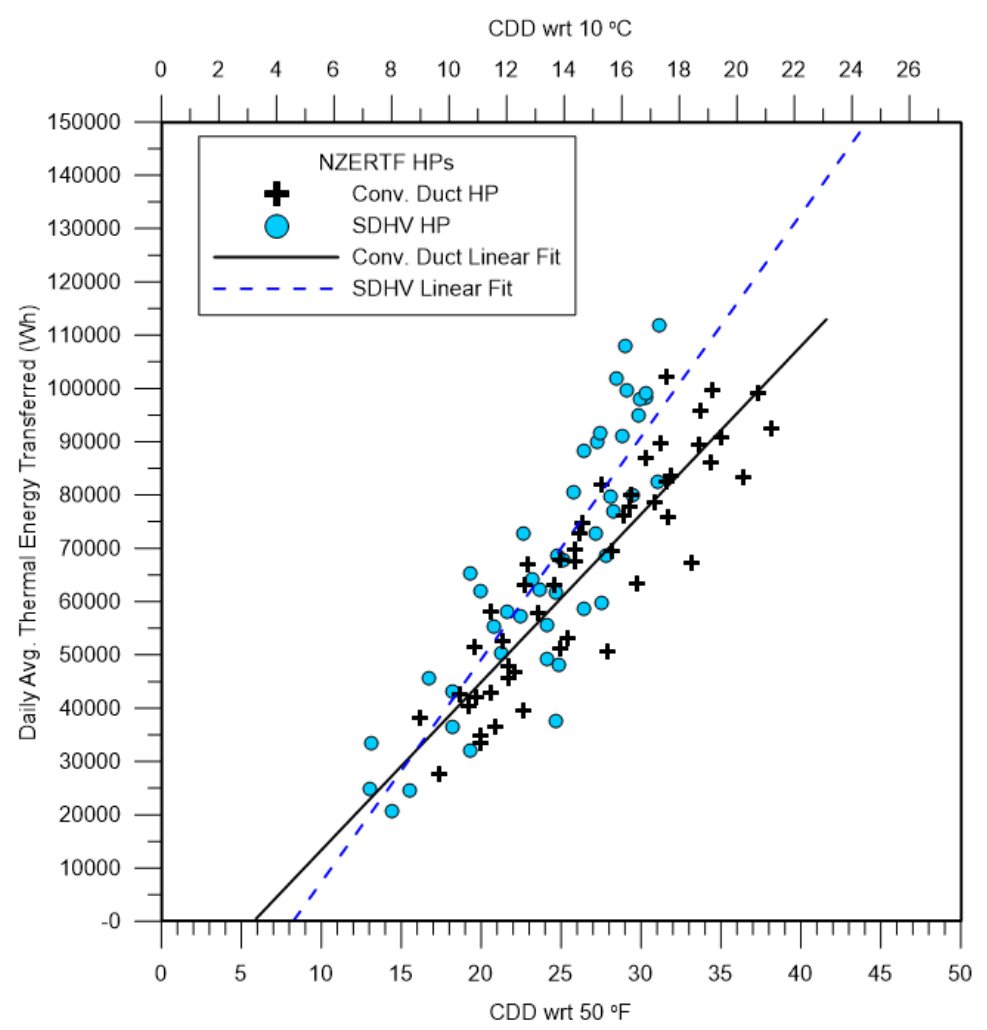

Figure 9: Cooling season thermal energy 
Figure 10 examines the daily average airflow rates of the two systems. The SDHV system operated at $(177 \pm 20) \mathrm{cfm}$ lower daily average airflow rates. Figure 11 shows the fan efficacy of the two systems as a function of their daily percent runtimes; the SDHV system clearly operates at a lower Watt per unit airflow rate due to its lower flowrate. Both systems utilized comparable electronically commutated motors (ECM). Although the two systems operated at differing airflow rates most of the time, they still circulated the same total volume of air in the house as shown in Fig. 12. This figure shows that the total number of house air changes as a function of CDD was statistically equivalent for the two systems. Although the SDHV system operated at lower total airflow rates, it operated for longer periods of time to produce equivalent total air changes. The operating times are shown more clearly in Fig. 13.

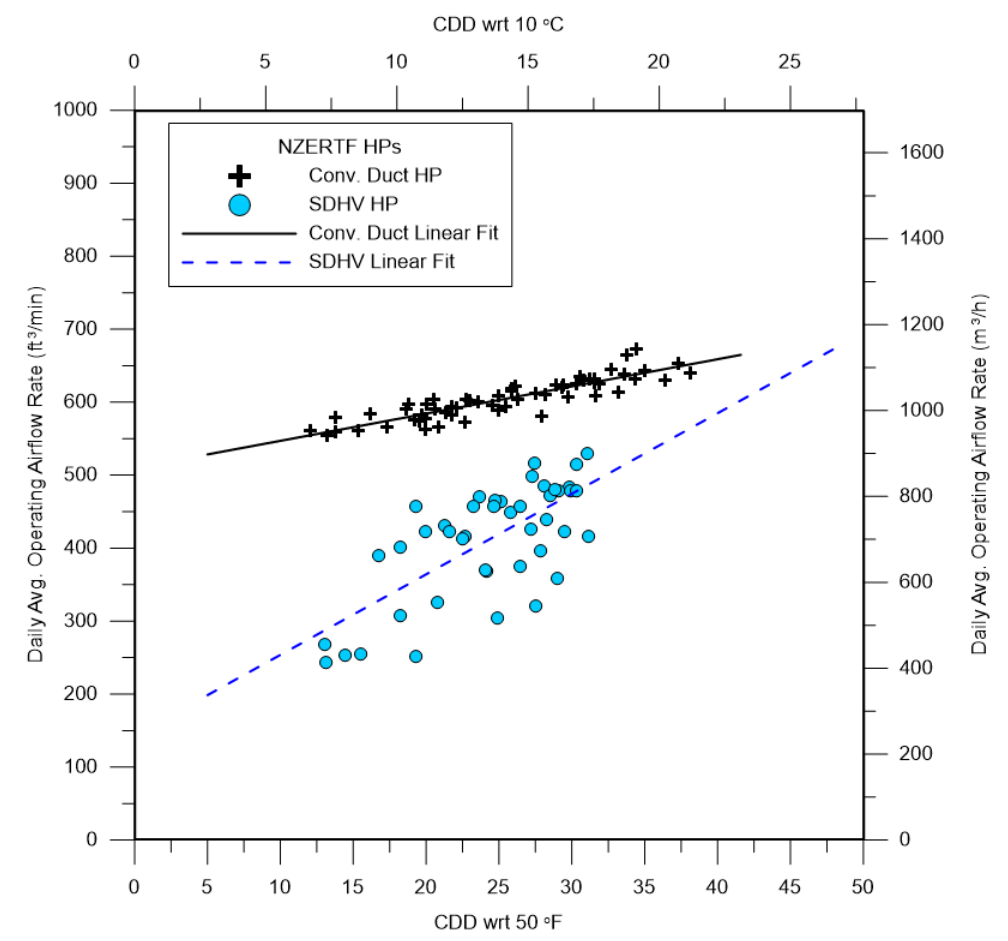

Figure 10: Cooling daily average operating airflow rates as a function of CDD 


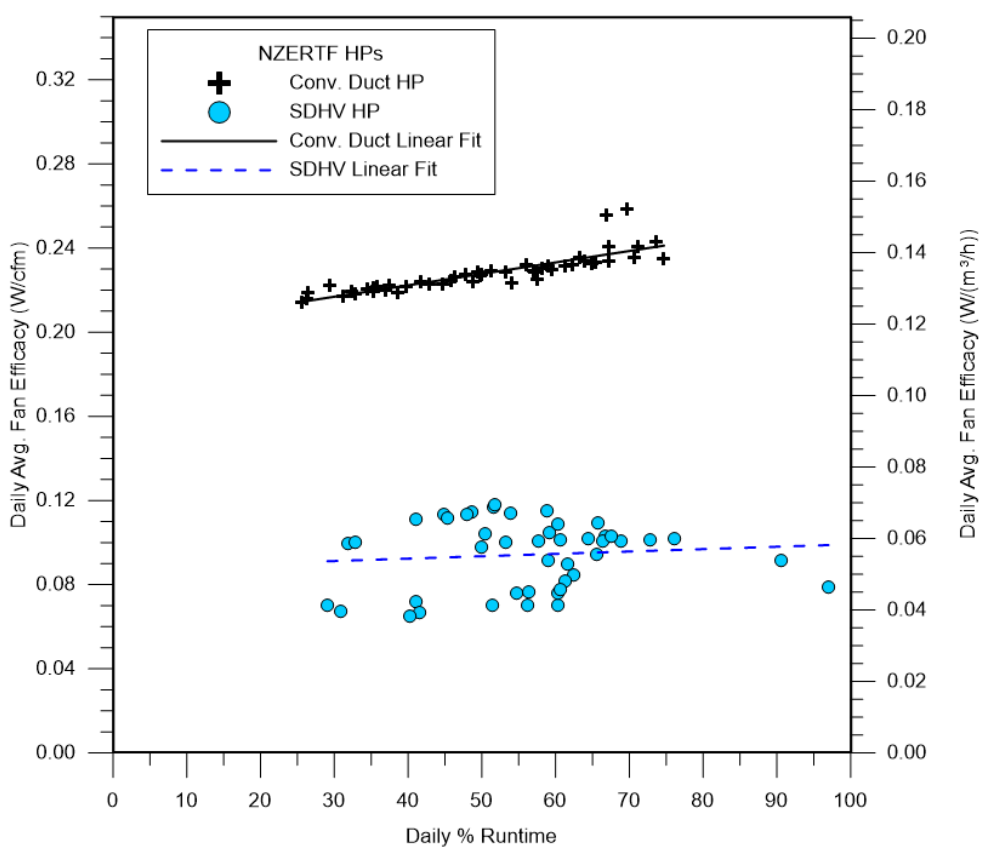

Figure 11: Cooling daily average indoor blower efficacy (W/(unit volume flow))

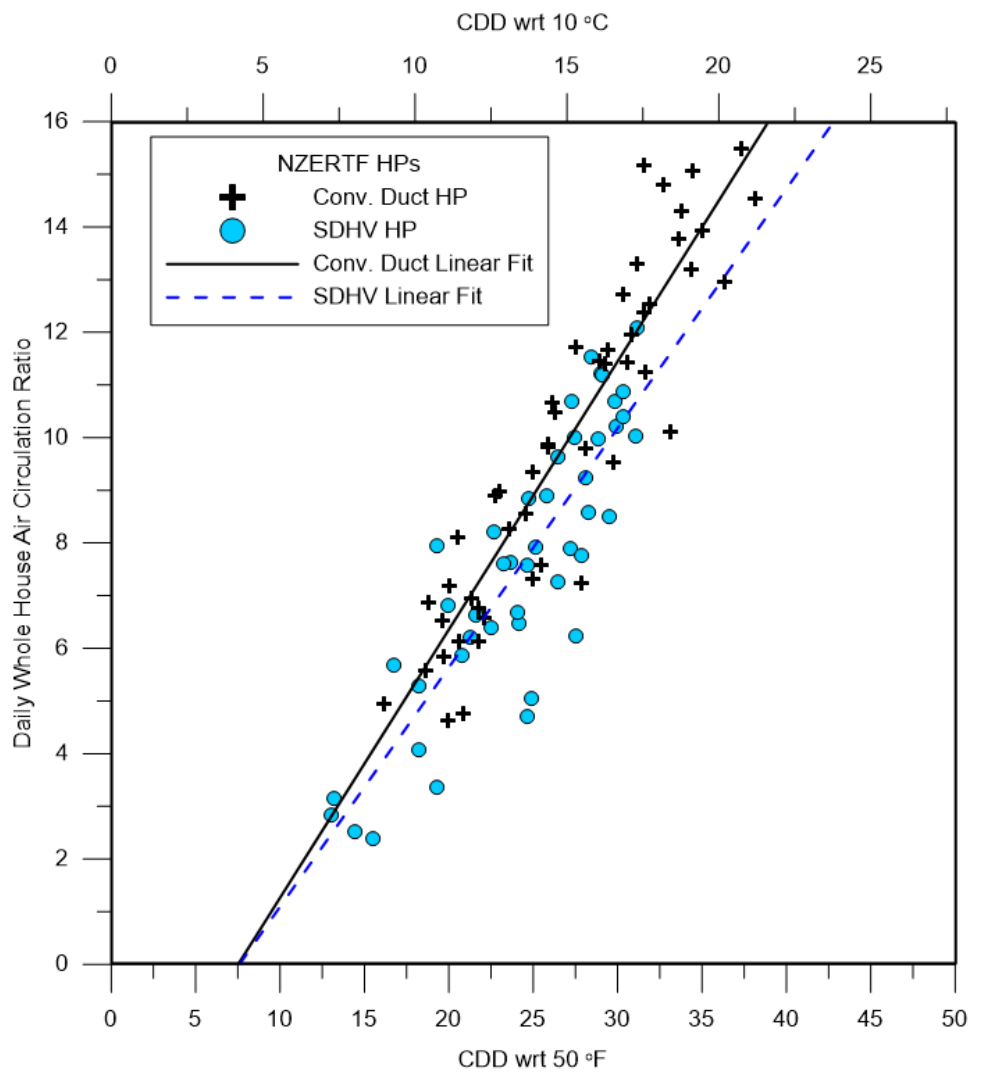

Figure 12: Daily cooling air circulation ratio (number of whole house air volume air-changes through the air handler) 


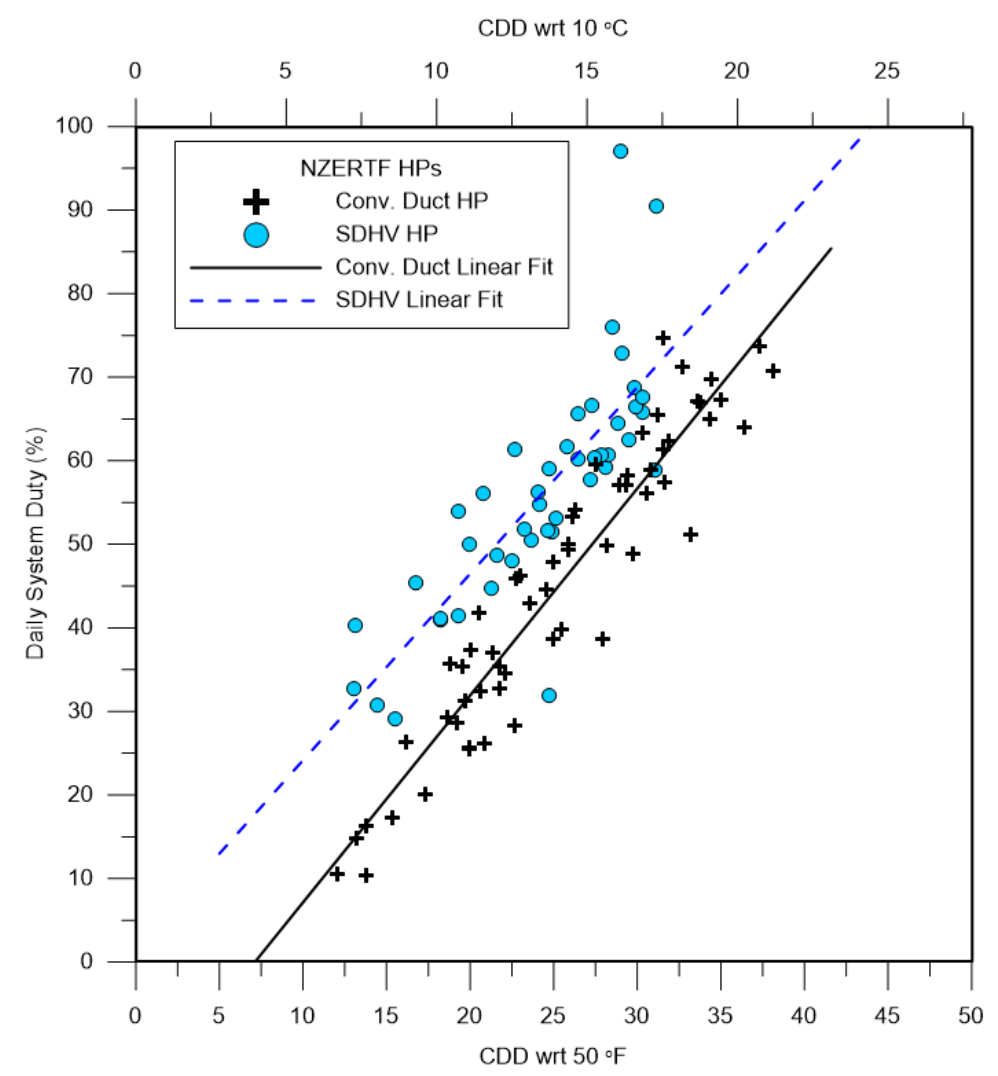

Figure 13: Cooling daily system percent duty

Remember that Figure 8 showed that the two systems used the same average daily electrical energy per CDD; yet, the SDHV system operated at a $(4.0 \pm 0.2)^{\circ} \mathrm{C}\left((7.27 \pm 0.44){ }^{\circ} \mathrm{F}\right)$ lower supply air temperature (Fig. 14) than the CDHP and a $3.70 \pm 0.22^{\circ} \mathrm{C}\left(6.66 \pm 0.42{ }^{\circ} \mathrm{F}\right)$ greater delta temperature (Fig. 15) across the air handler than the CDHP. Figure 16 shows that the two systems had comparable average return air temperatures with the SDHV averaging slightly lower than the CDHP $\left((-0.33 \pm 0.10)^{\circ} \mathrm{C}\left(\left(-0.60 \pm 0.18^{\circ} \mathrm{F}\right)\right)\right)$. 


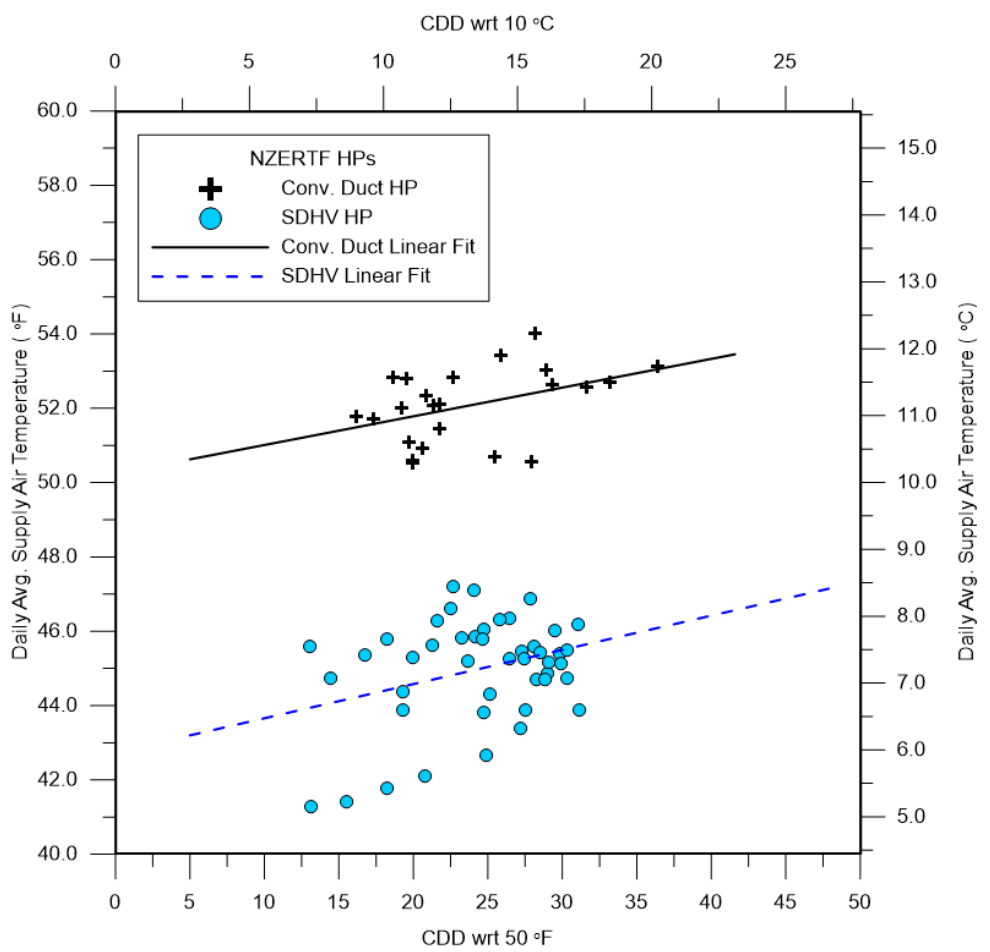

Figure 14: Cooling average operating supply air temperatures

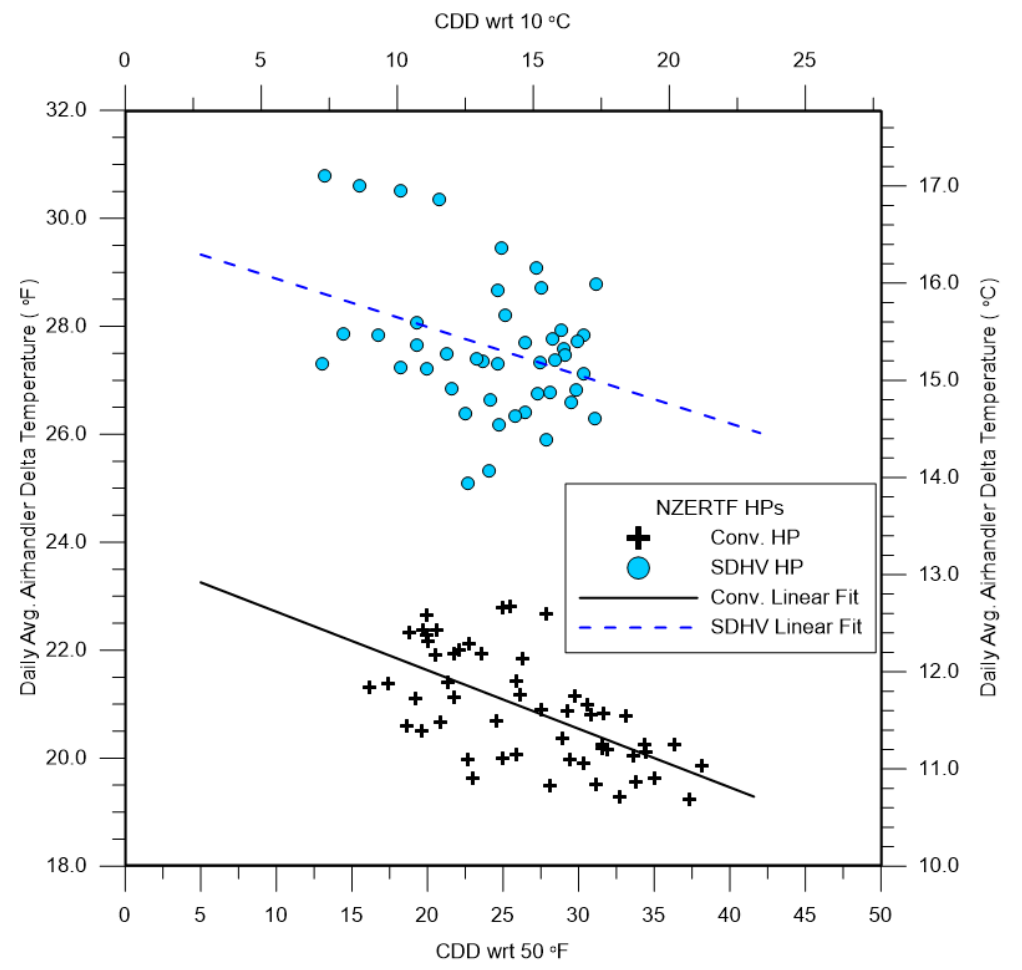

Figure 15: Cooling average operating indoor unit air temperature change 


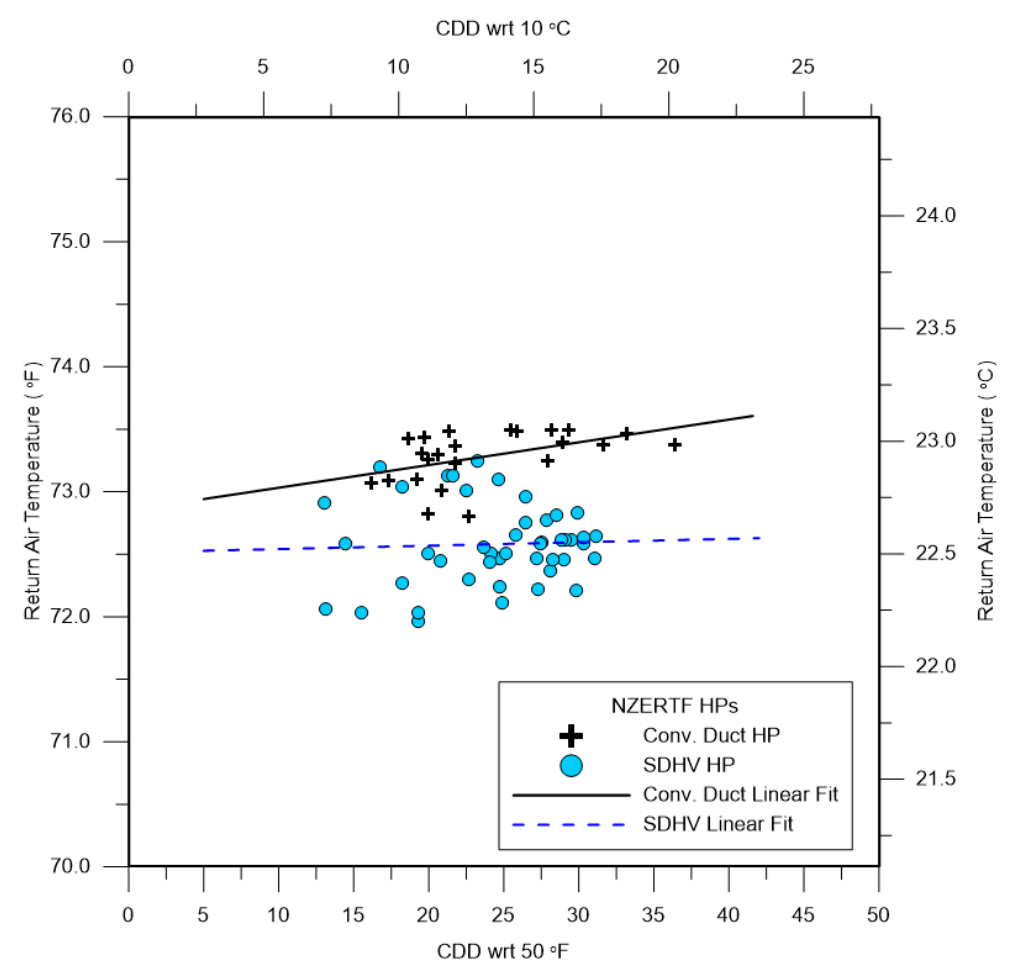

Figure 16: Cooling daily average operating return air temperatures

\subsubsection{Cooling Standby Energy Use}

Table 3 shows the average power demand during standby for the two systems. During standby, the system is not performing any cooling, heating, or ventilation functions. Any electrical energy that is consumed is not being used to condition the space, and it is a waste of energy that reduces overall space conditioning efficiency. The system is still powered-up, and the indoor unit and outdoor unit controls are consuming energy. The large difference between the power demands is due to the difference in the type of low voltage transformer used by the two systems; the SDHV uses a toroidal transformer while the CDHP uses an E-core, laminated steel plate type transformer. Figure 17 shows the two different types of transformers installed in the systems. Figure 18 shows that the indoor standby energy use of the SDHV system averaged (113.5 \pm 7.0) Wh per day less than the CDHP while the outdoor standby averaged $(222.3 \pm 14.3) \mathrm{Wh}$ less (Fig. 19). These results combined for the SDHV system to produce a total daily standby energy use that was $(335.8 \pm 21.3)$ Wh less than the CDHP.

Table 3: Cooling standby power demand

\begin{tabular}{|c|c|c|}
\hline System & Indoor standby (W) & Outdoor standby (W) \\
\hline CDHP & 11.9 & 23.4 \\
\hline SDHV & 3.9 & 7.7 \\
\hline$\%$ difference wrt CDHP & $-67 \%$ & $-67 \%$ \\
\hline
\end{tabular}



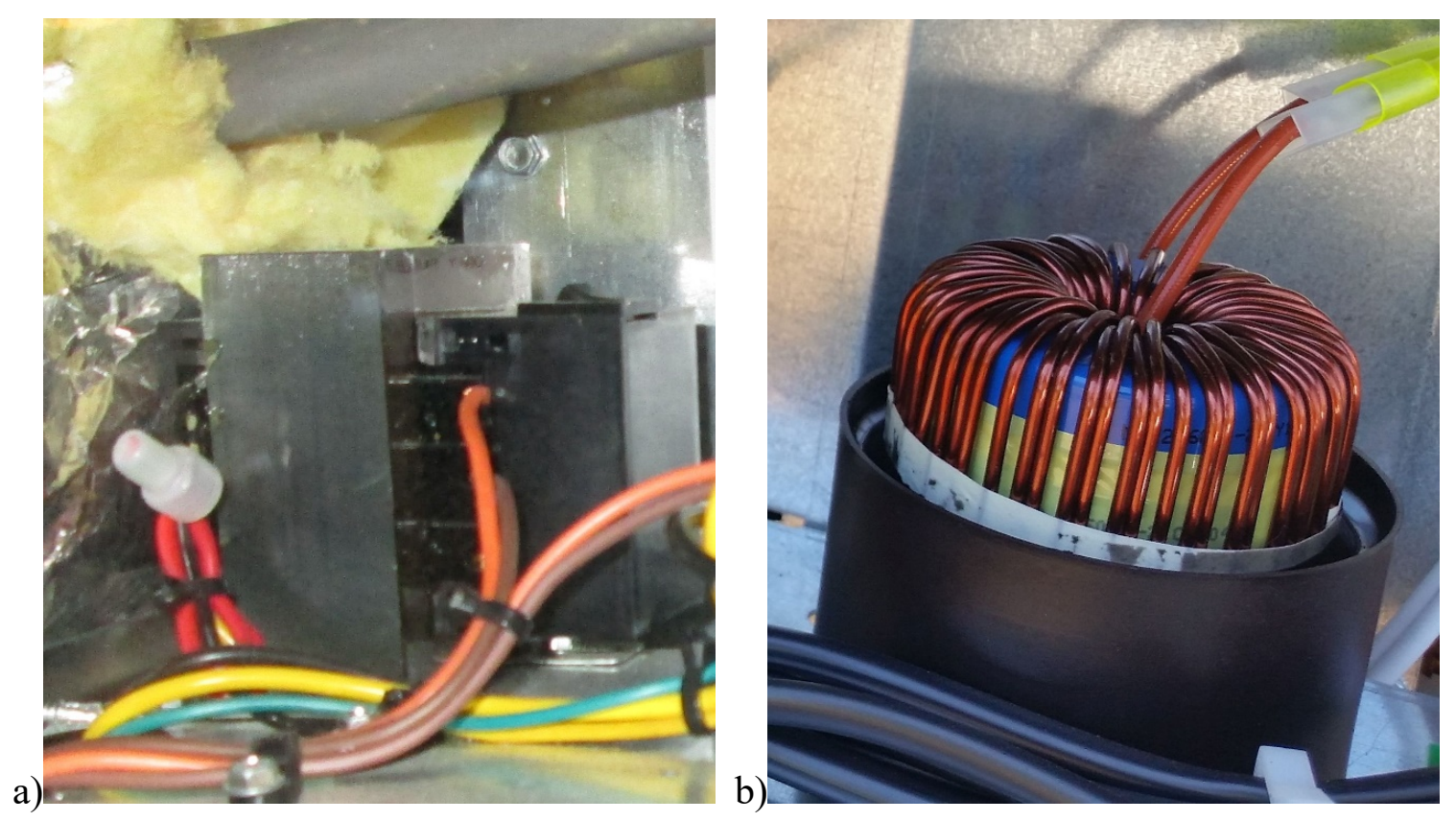

Figure 17: Low voltage transformers in the two systems, a) CDHP E-core laminated plate and b) SDHV toroidal

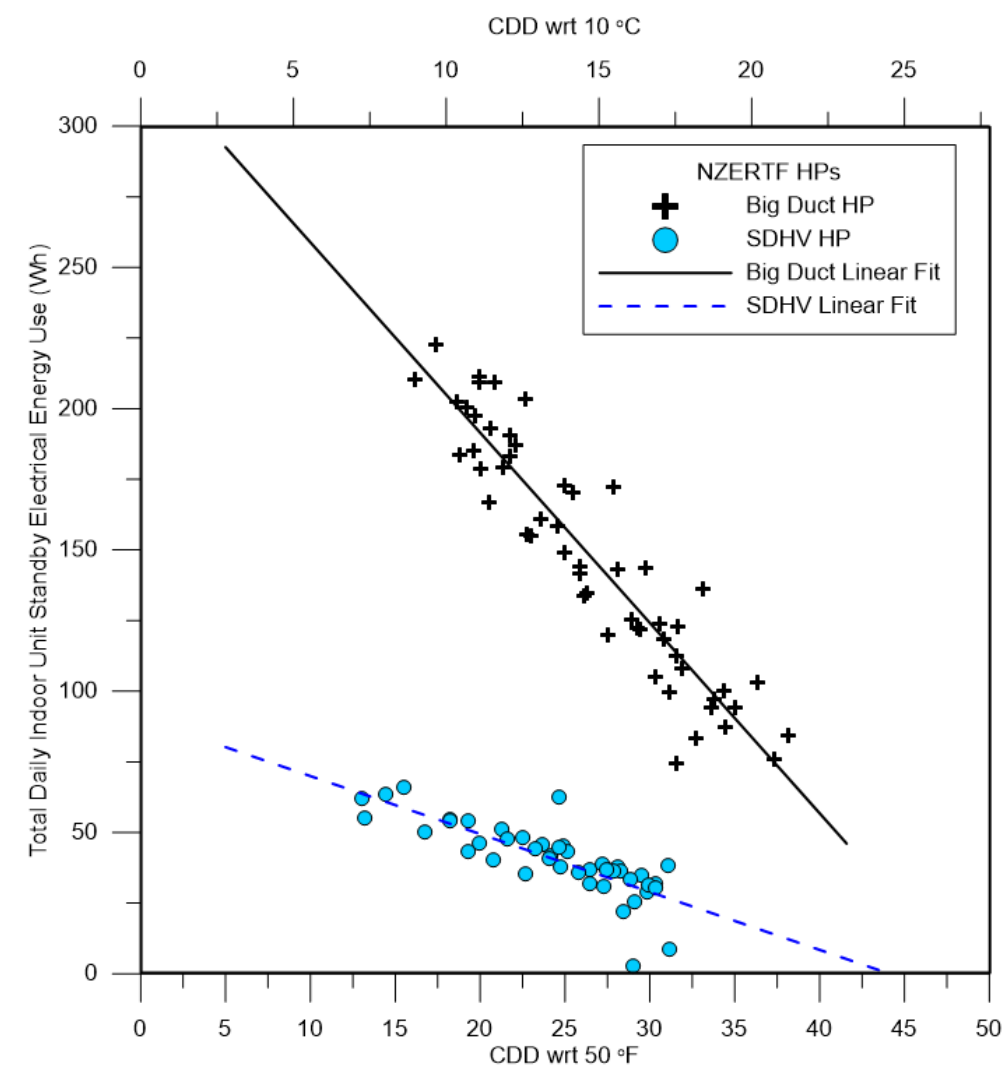

Figure 18: Cooling indoor unit daily standby energy use 


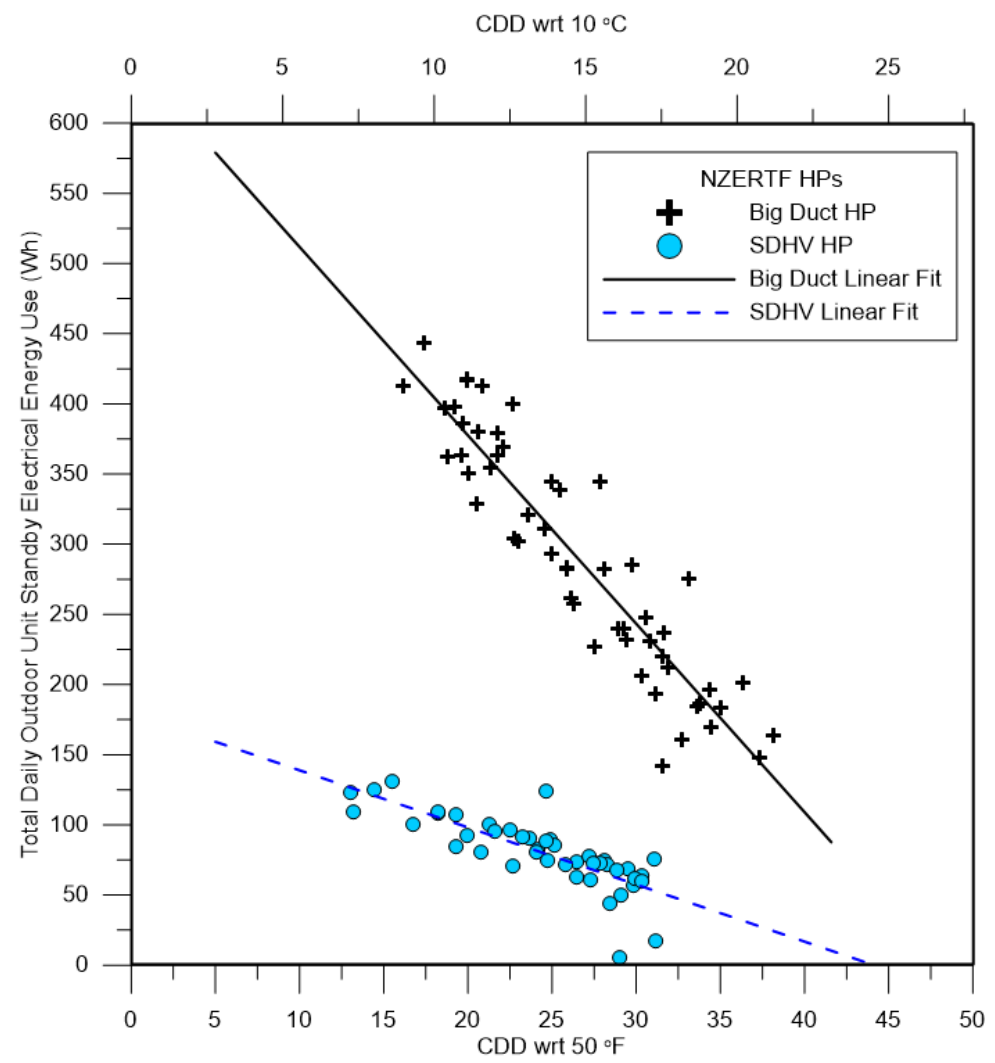

Figure 19: Cooling outdoor unit daily standby energy use

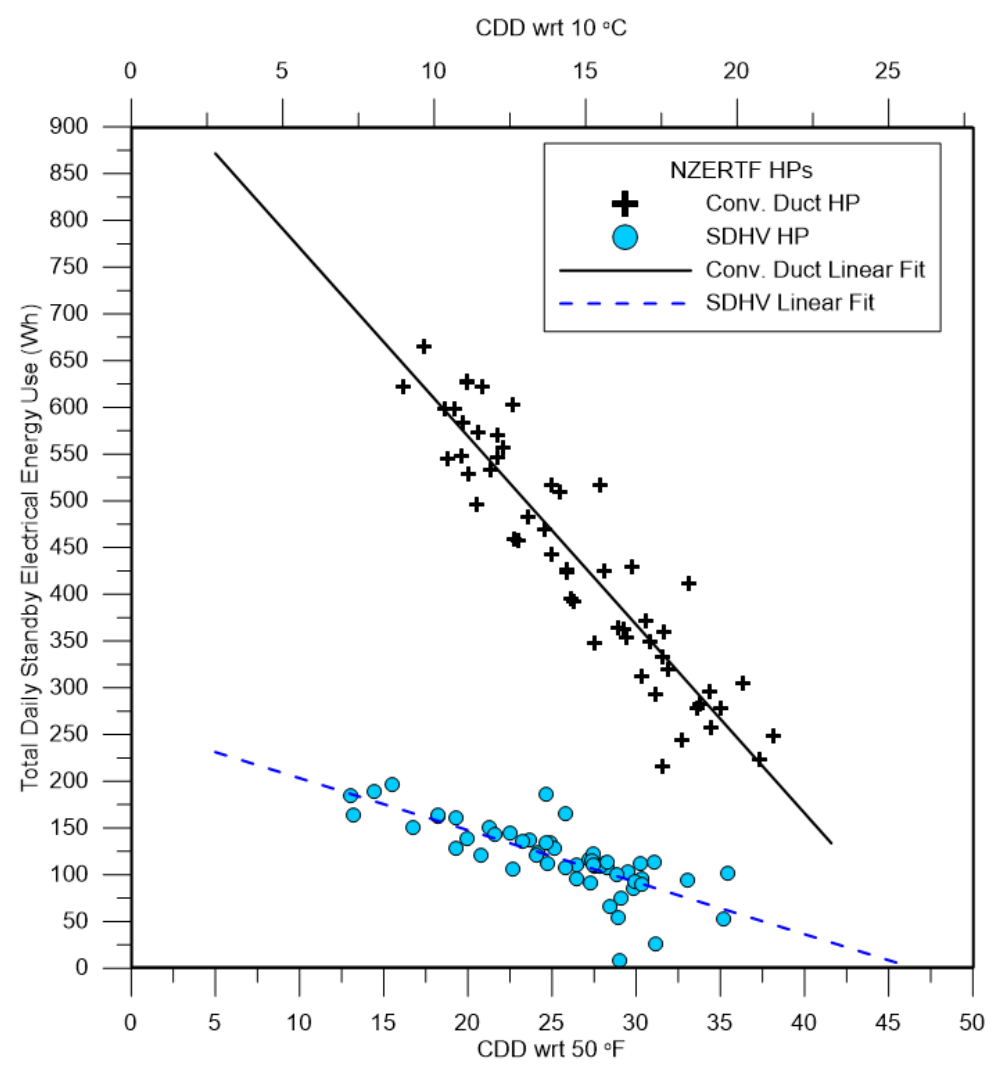

Figure 20: Cooling system daily total standby energy use 


\subsubsection{Cooling Efficiency}

Figure 21 shows the cooling coefficient of performance (COP) as a function of CDD's. There is more scatter in the variable speed COP data than for the two-stage HP. The SDHV system averaged a slightly higher COP for the cooling season being $(0.396 \pm 0.113)$ higher than the CDHP. Figures 22 and 23 show the compressor suction and discharge refrigerant saturation temperatures, respectively, for a comparable day for the two systems. In Fig. 22 the CDHP has an ON-cycle from approximately 700 to $2400 \mathrm{sec}$ while the SDHV system is running continuously over that same time. Figure 22 shows that the evaporator saturation temperature of the CDHP is $5{ }^{\circ} \mathrm{C}(9 \mathrm{~F})$ higher than the SDHV while the discharge saturation temperatures are within $2{ }^{\circ} \mathrm{C}(3.6 \mathrm{~F})$ of each other. This means that the SDHV system was operating at a higher temperature lift than the CDHP. The temperature lift for the two systems is shown in Fig. 24; if we neglect the hunting behavior of the SDHV system between 1000 and $2000 \mathrm{sec}$, the SDHV operated with approximately $35^{\circ} \mathrm{C}\left(63{ }^{\circ} \mathrm{F}\right)$ lift and the CDHP operated with $27^{\circ} \mathrm{C}$ $\left(49^{\circ} \mathrm{F}\right)$ lift. If everything else were equal, the CDHP should have a higher COP because it was operating at a lower lift, yet Fig. 25 shows that the instantaneous COP was better for the SDHV system. The reasons are shown in Figs. 26 and 27 where we see the instantaneous power and capacity, respectively: the capacity is equivalent, but the power demand of the SDHV system is less. The SDHV system showed this behavior consistently; producing higher COP even though it was operating at a higher lift (condenser refrigerant saturation temperature and evaporator saturation temperature difference). This behavior could have been modified in the control system to raise the evaporator saturation temperature when there was less need for dehumidification, thus increasing COP during more of the operating time.

Figure 28 shows a comparison of the daily average COP as a function of the daily average outdoor dry-bulb temperature. The SDHV, variable-speed system tended to operate at higher COPs for most of the outdoor conditions shown. The CDHP experienced higher temperature degree days but maintained good COP running at its lowest stage. Even on the highest temperature days, the CDHP operated at its low stage capacity. The higher temperatures experienced by the CDHP lowered its average COP compared to the SDHV. 


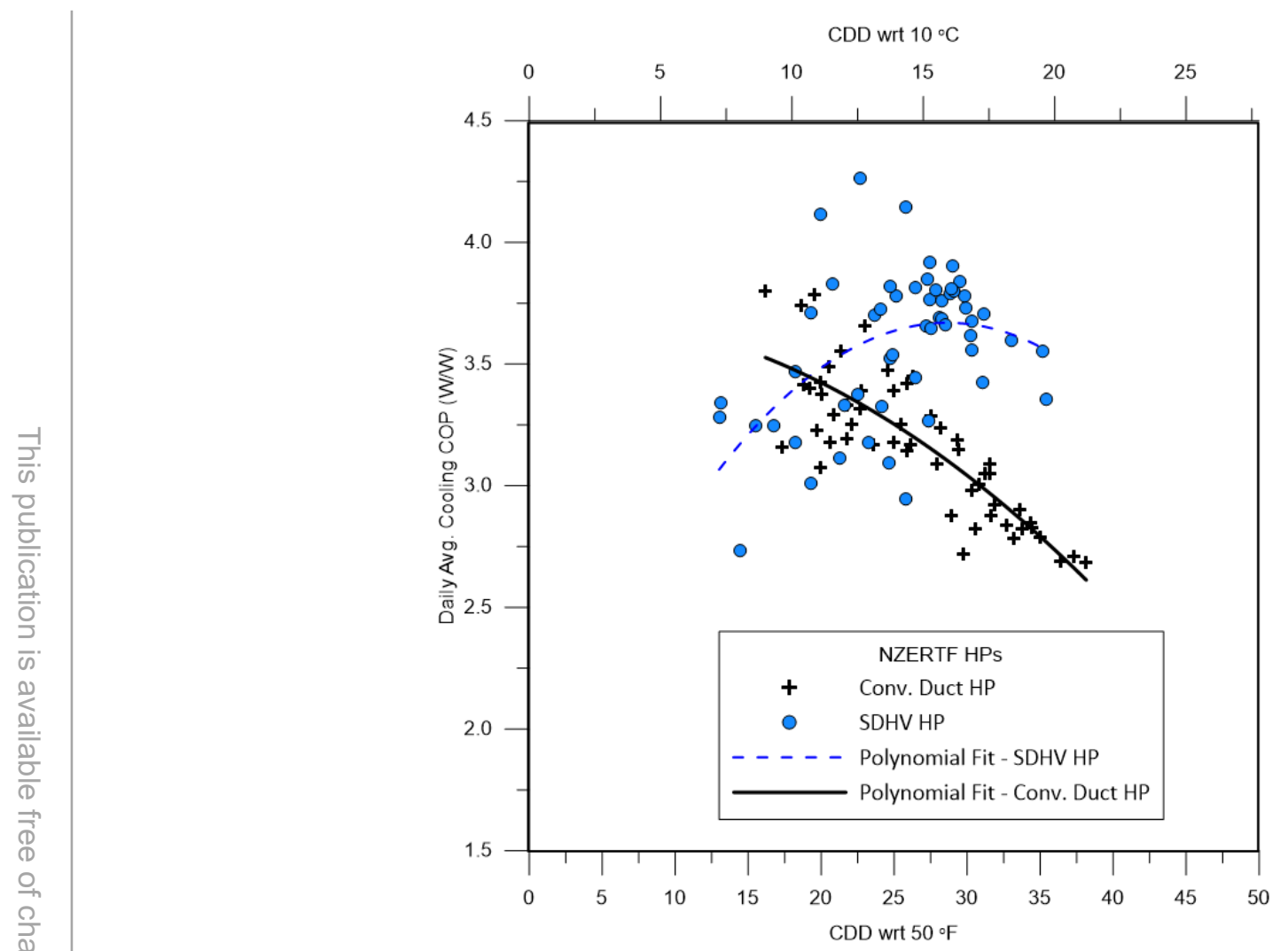

Figure 21: Cooling season coefficient of performance (COP)

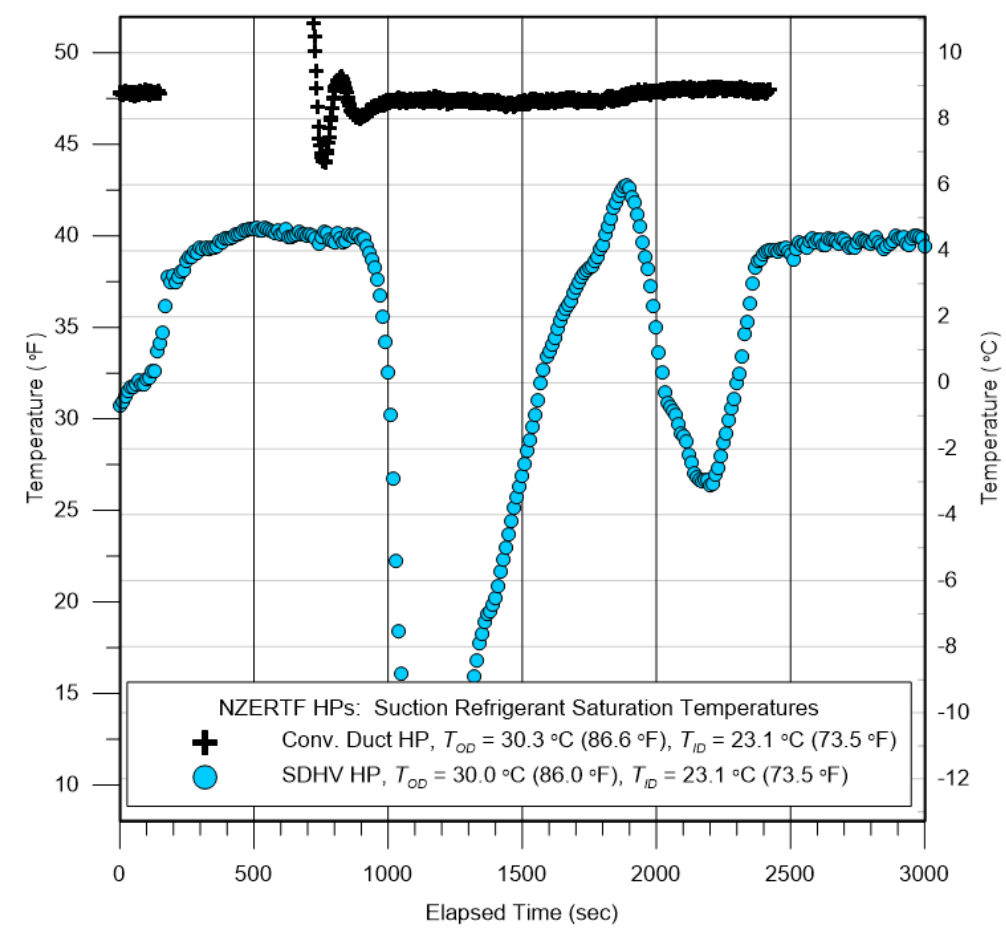

Figure 22: Cooling suction refrigerant saturation temperature example 


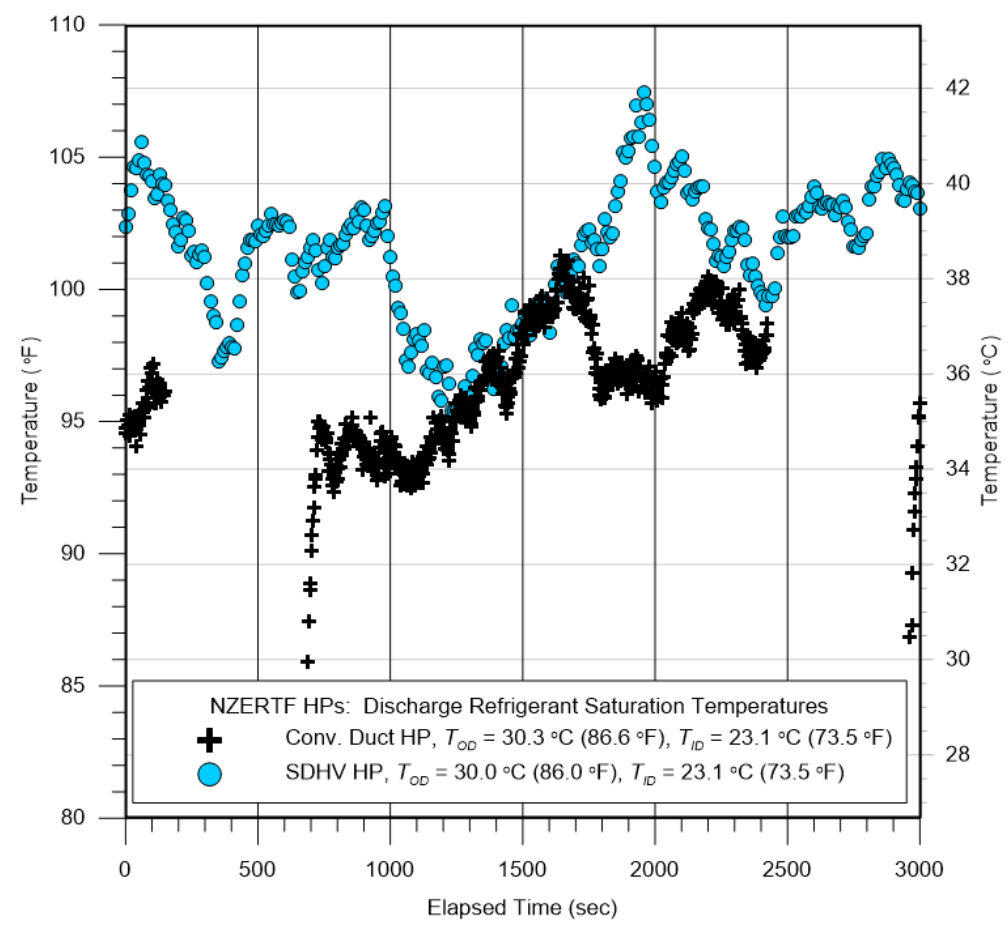

Figure 23: Cooling discharge refrigerant saturation temperature example

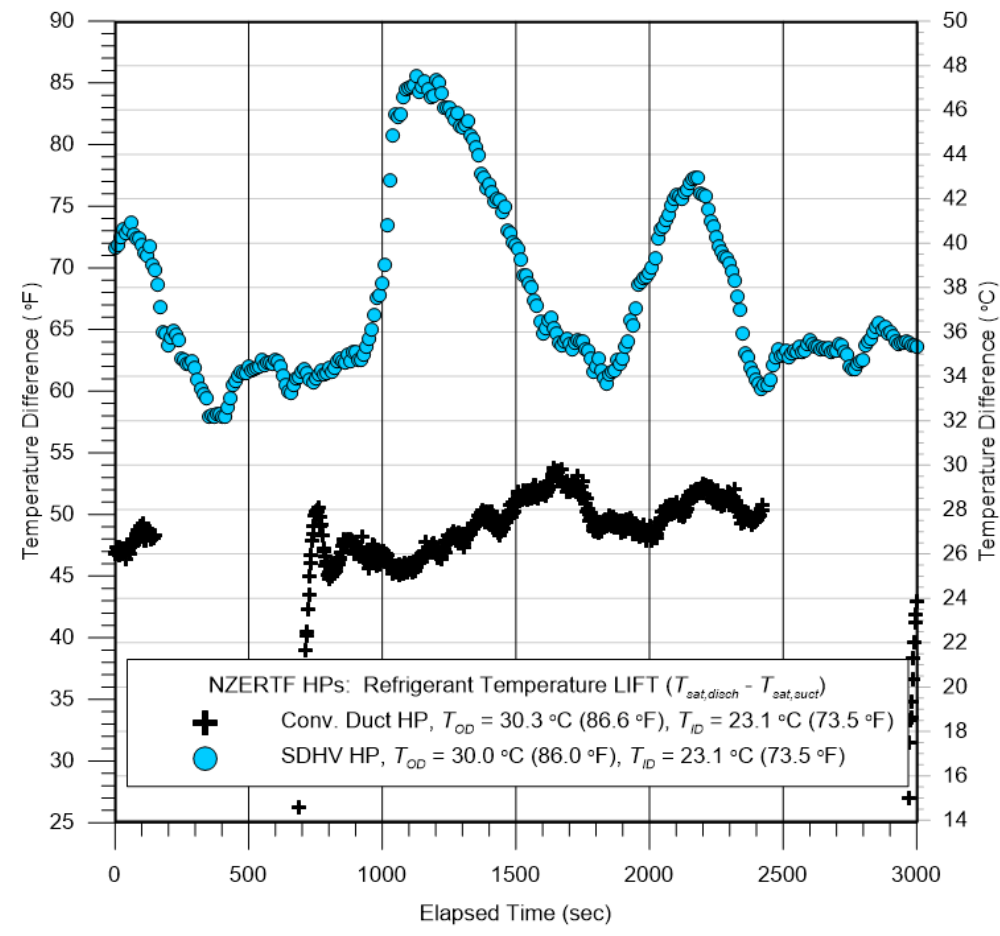

Figure 24: Cooling temperature lift example 


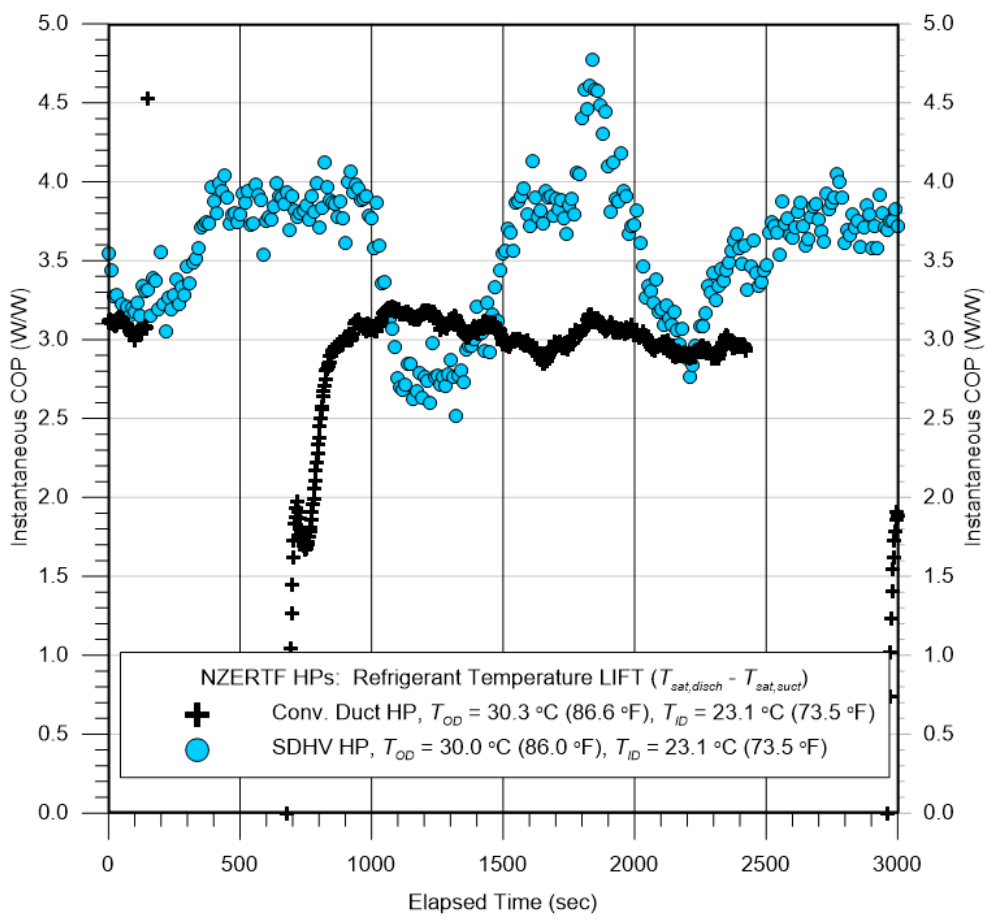

Figure 25: Cooling instantaneous COP example

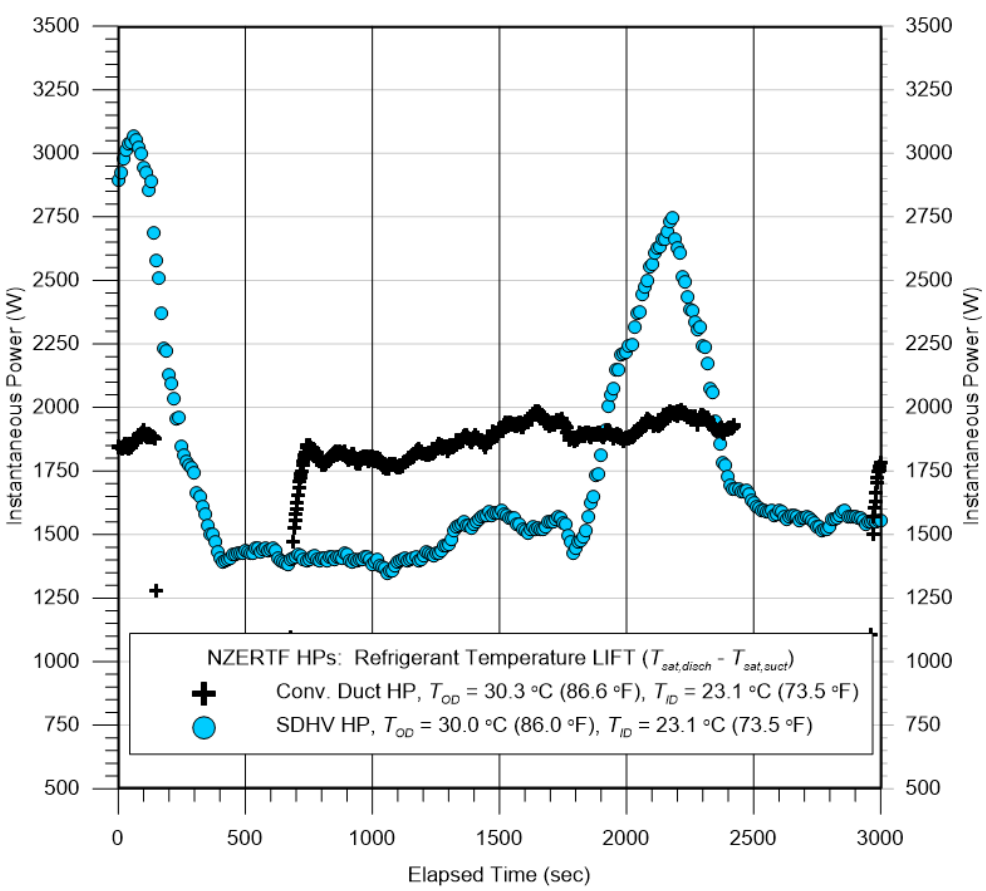

Figure 26: Cooling instantaneous power example 


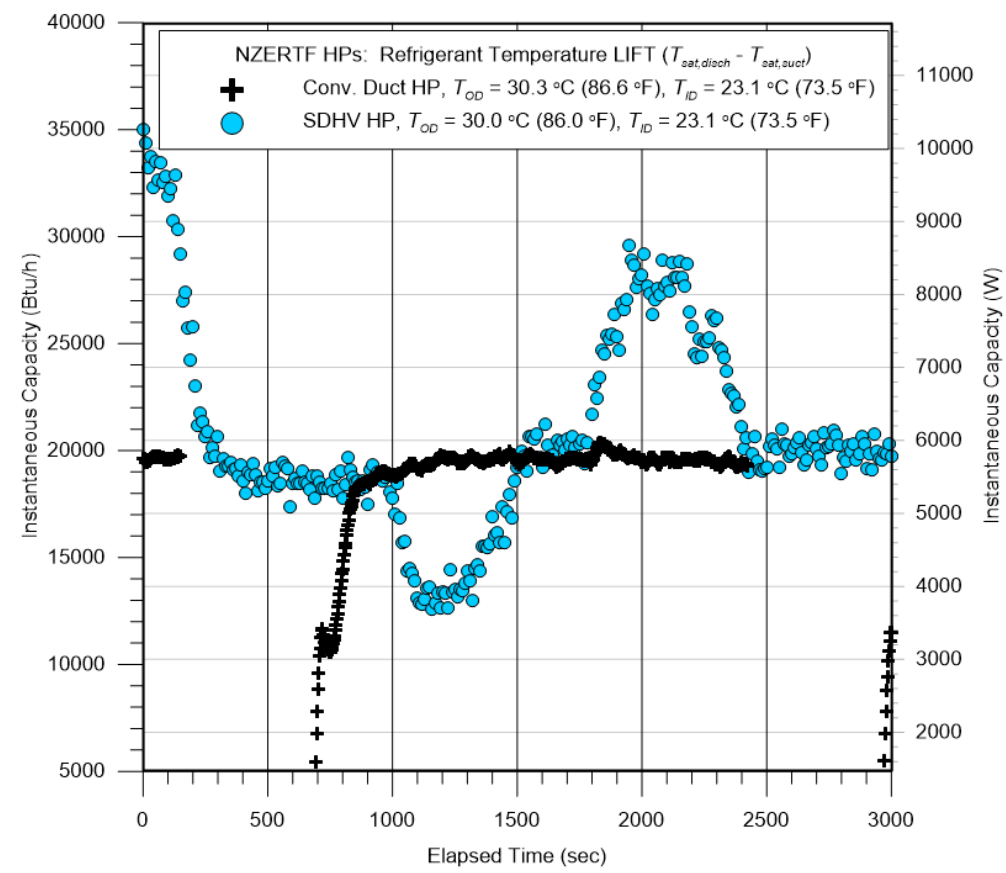

Figure 27: Cooling instantaneous capacity example

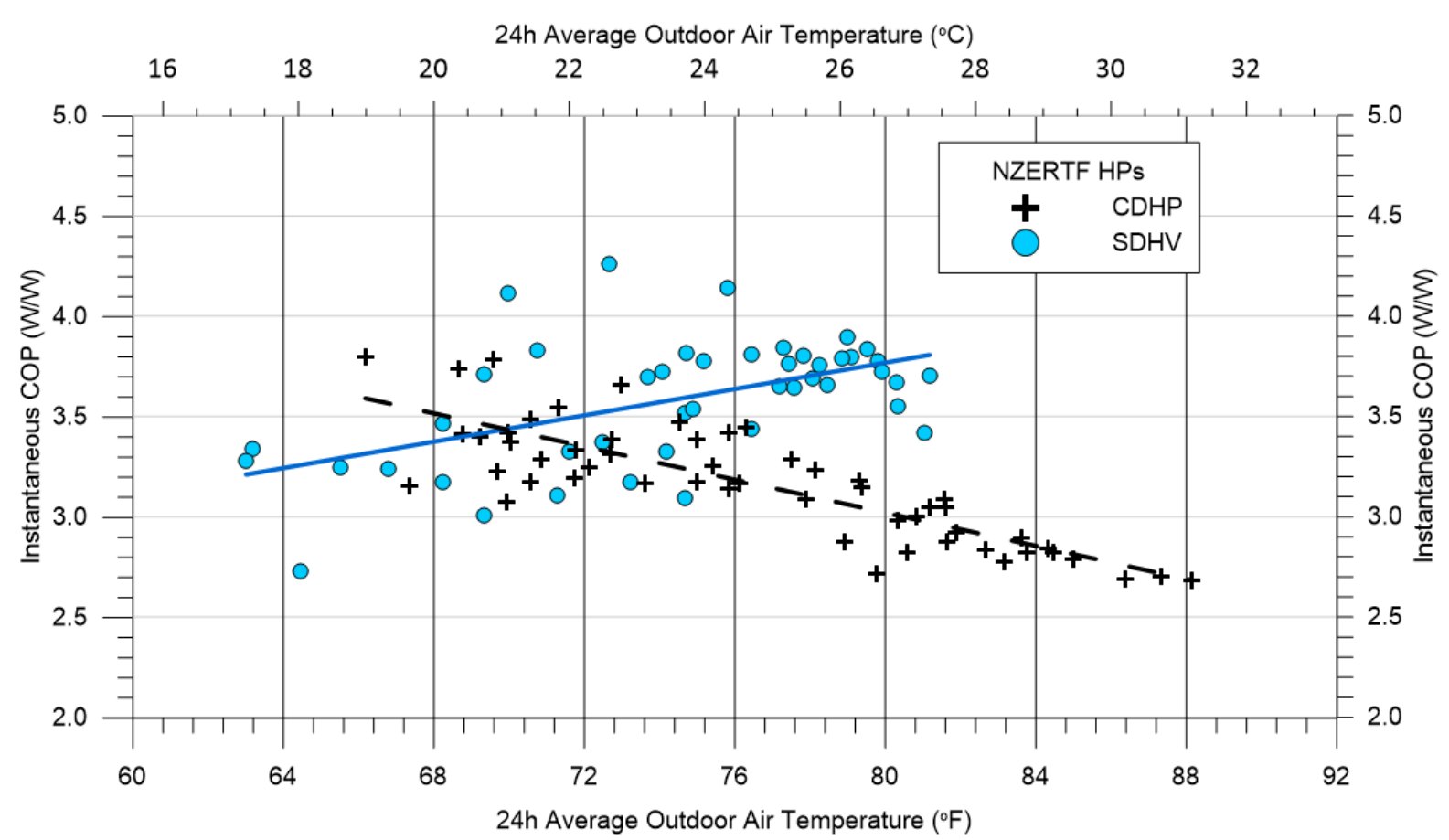

Figure 28: Cooling COP as a function of daily average outdoor temperature

\section{2. $\quad$ Heating Season}

Figure 29 compares the heating degree days with an $18.3^{\circ} \mathrm{C}\left(65^{\circ} \mathrm{F}\right)$ reference for the two heat pump systems. The heating season went from November 16, 2016 to April 2, 2017. The SDHV system had $22.4 \%$ more HDD's than the CDHP even though they were operating on a 
weekly alternating schedule. For the heating season, as in the cooling season, degree days are used in the plots to normalize the results.

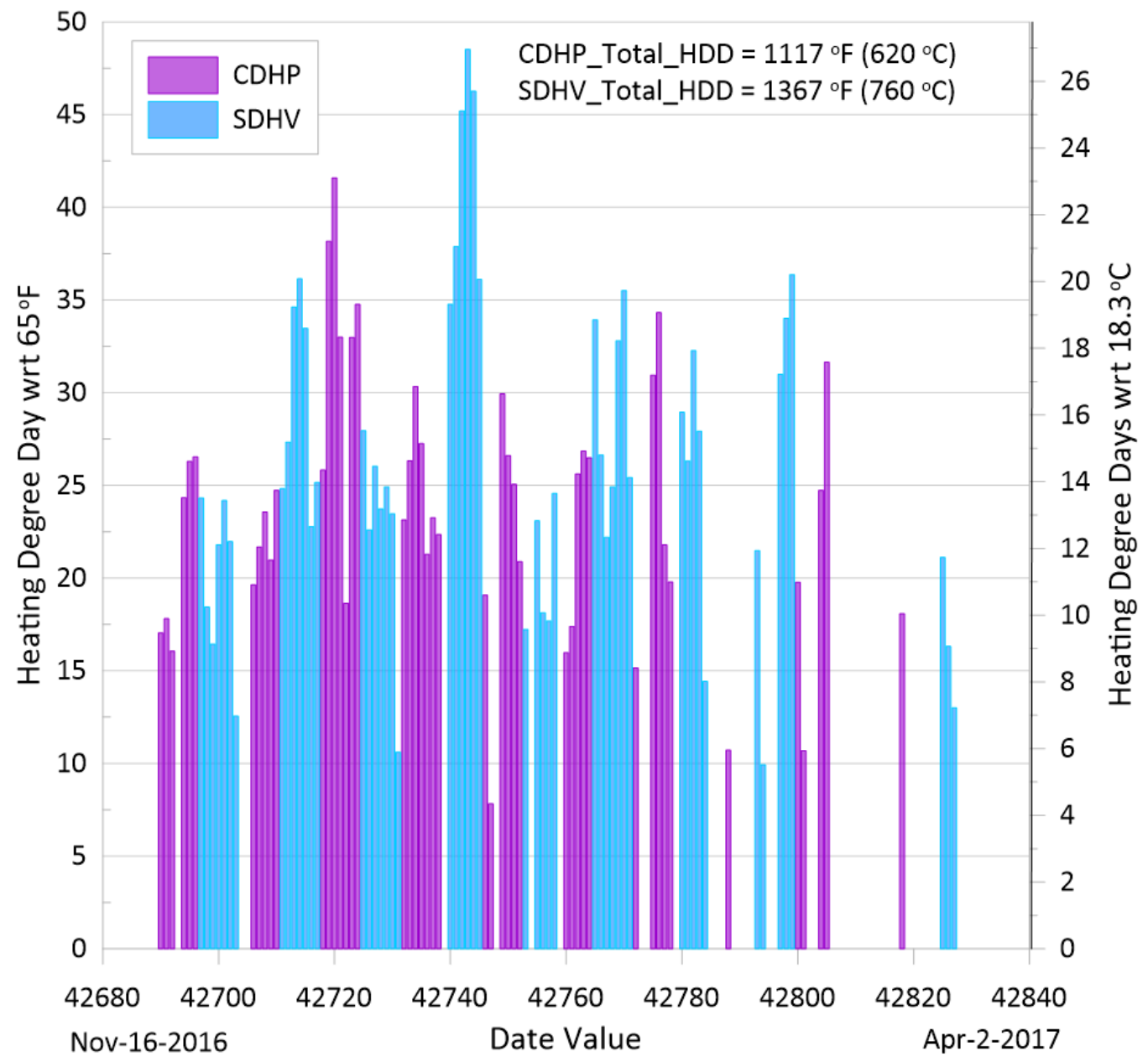

Figure 29: Heating degree days for the CDHP and SDHV

\subsubsection{Heating Energy}

Figure 30 shows the daily average electrical energy consumed by the systems as a function of HDD. Due to the higher number of HDD's, the SDHV consumed $31.4 \%$ more electrical energy over the heating season. The daily electrical energy usage per HDD for the CDHP and the SDHV (Fig. 31) were $(1975 \pm 355) \mathrm{Wh}^{\circ} \mathrm{C}^{-1}\left((1097 \pm 197) \mathrm{Wh}^{\circ} \mathrm{F}^{-1}\right)$ and $(1931 \pm 243) \mathrm{Wh}^{\circ} \mathrm{C}^{-1}$ $\left((1073 \pm 135) \mathrm{Wh}^{\circ} \mathrm{F}^{-1}\right)$, respectively. The difference in heating season electrical energy usage per HDD was statistically insignificant. The daily thermal energy transferred per HDD (Fig. 32) for the CDHP and the SDHV were $(860 \pm 208) \mathrm{Wh}^{\circ} \mathrm{C}^{-1}\left((1548 \pm 374) \mathrm{Wh}^{\circ} \mathrm{F}^{-1}\right)$ and $(939 \pm 173) \mathrm{Wh}^{\circ} \mathrm{C}^{-1}\left((1690 \pm 311) \mathrm{Wh}^{\circ} \mathrm{F}^{-1}\right)$, respectively. The difference in cooling season thermal energy removed per HDD was statistically insignificant. 


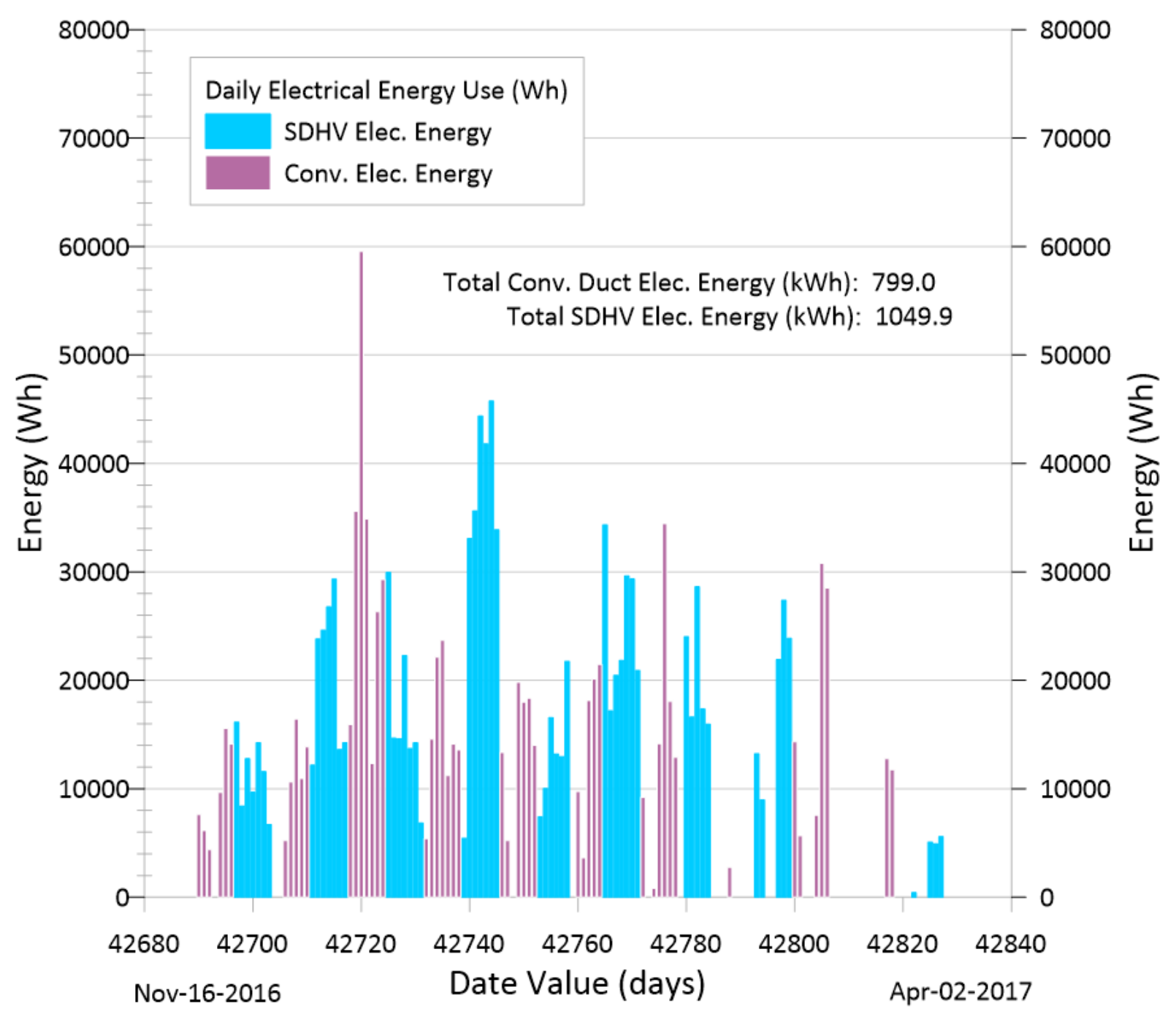

Figure 30: Heating season daily and total electrical energy use 


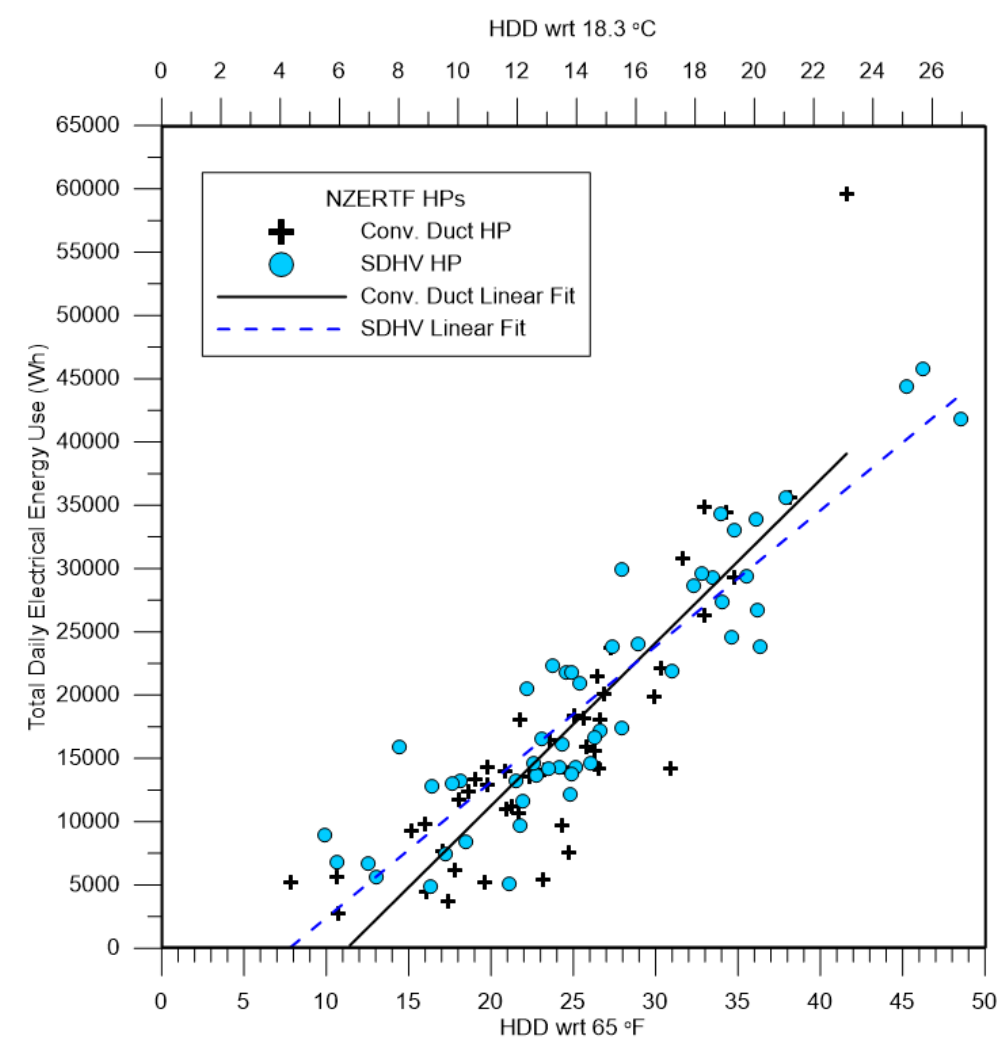

Figure 31: Heating season electrical energy use as a function of HDD's

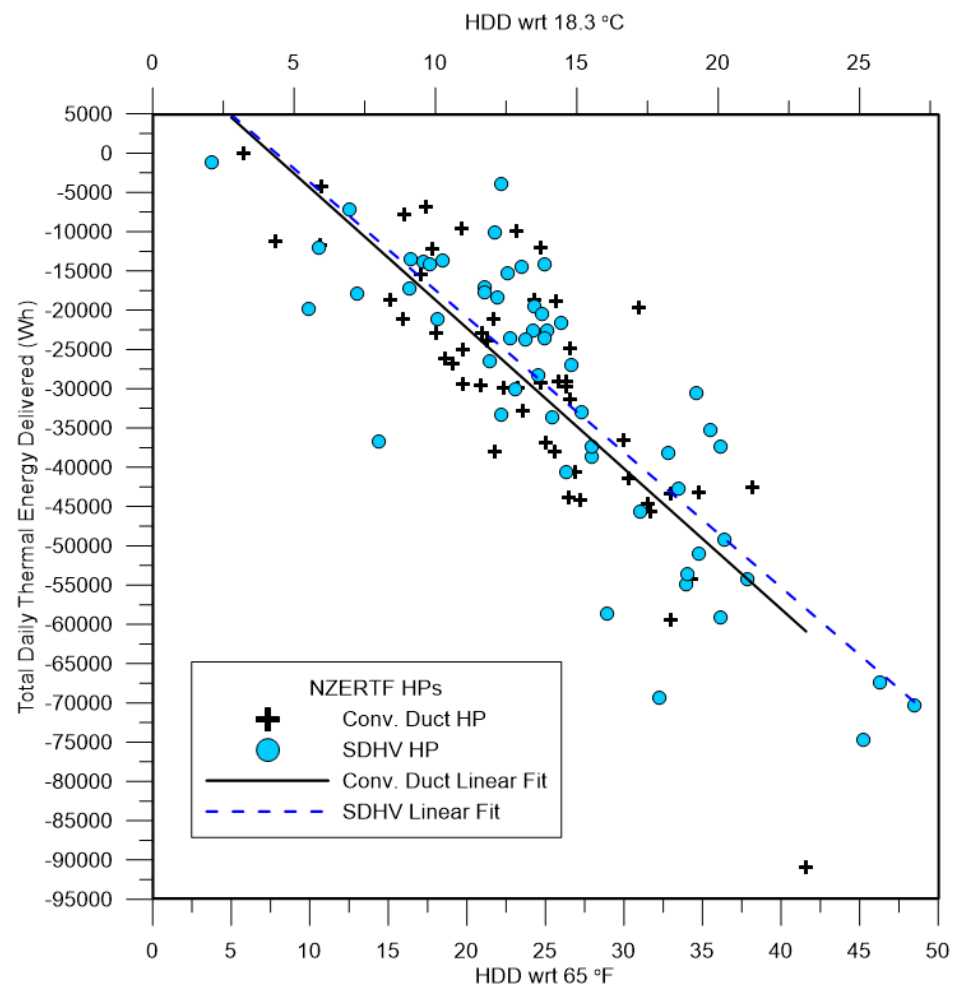

Figure 32: Heating season thermal energy delivered 
Figure 33 shows that the SDHV system operated at a lower average daily airflow rate than the CDHP; the SDHV operated $(625 \pm 53.2) \mathrm{m}^{3} \mathrm{~h}^{-1}((368 \pm 31.3) \mathrm{cfm})$ lower average airflow than the CDHP. Similar to the cooling mode the SDHV indoor blower operated in a more efficient range (Fig. 34). Unlike the cooling mode, the SDHV circulated an average of (3.6 \pm 0.8$)$ fewer air changes (Fig. 35) while operating about the same number of hours per day (Fig. 36). The SDHV had a higher supply air delivery temperature (Fig. 37) and a higher average temperature change across the air handler $\left((13.9 \pm 1.6){ }^{\circ} \mathrm{C}\left((25 \pm 2.8){ }^{\circ} \mathrm{F}\right)\right.$ higher, Fig. 38). House average return air temperatures were equivalent (Fig. 39). The SDHV system was delivering higher energy supply air to meet the load at a lower airflow rate.

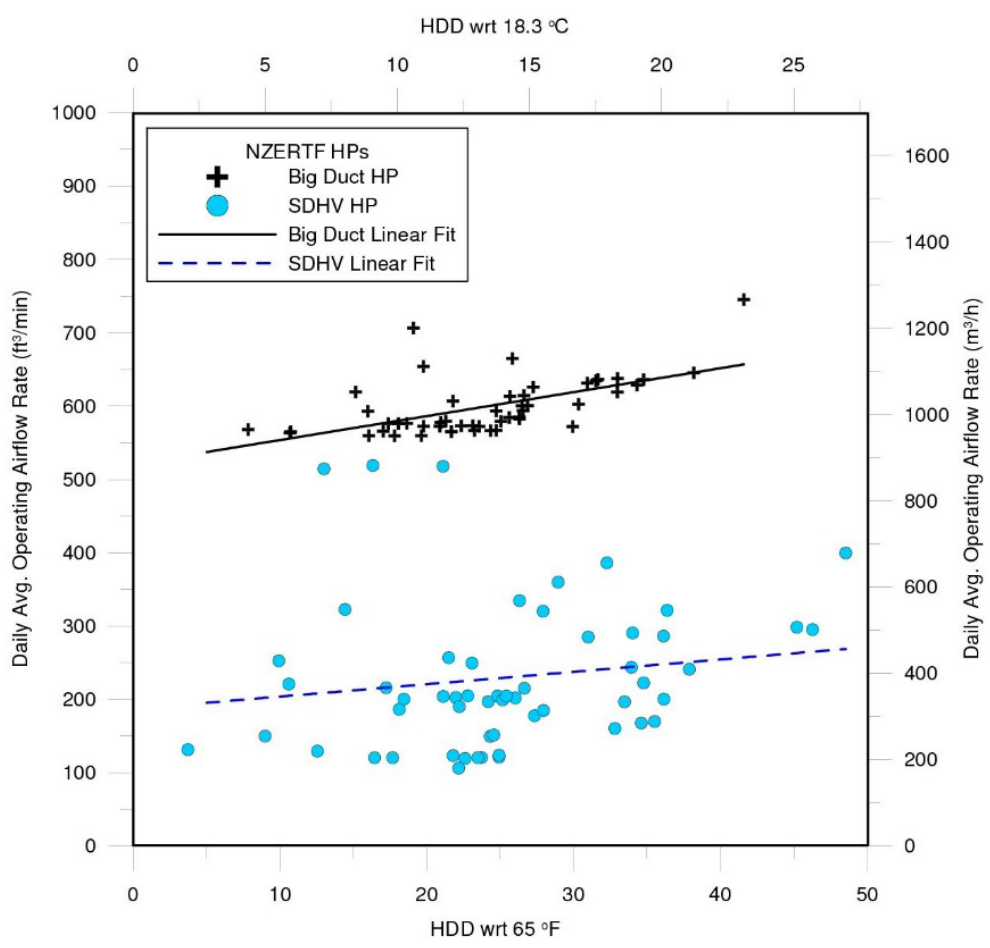

Figure 33: Heating daily average operating airflow rates 


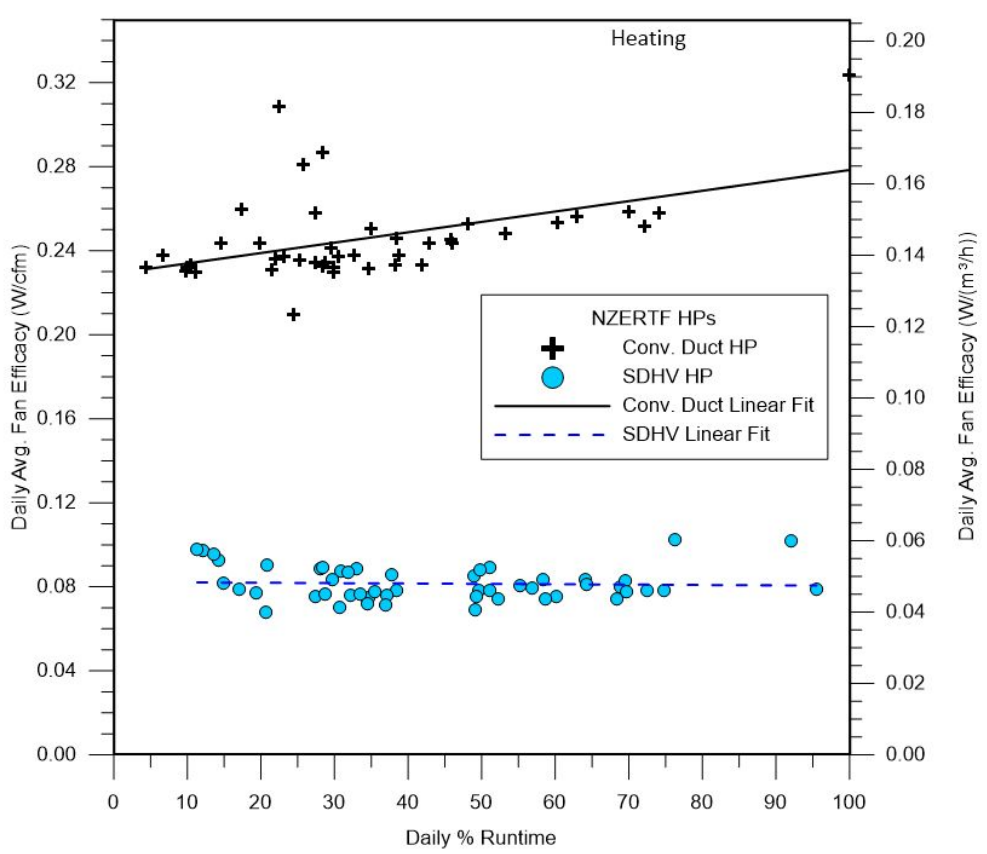

Figure 34: Heating average indoor blower efficacy (W/(unit volume flow))

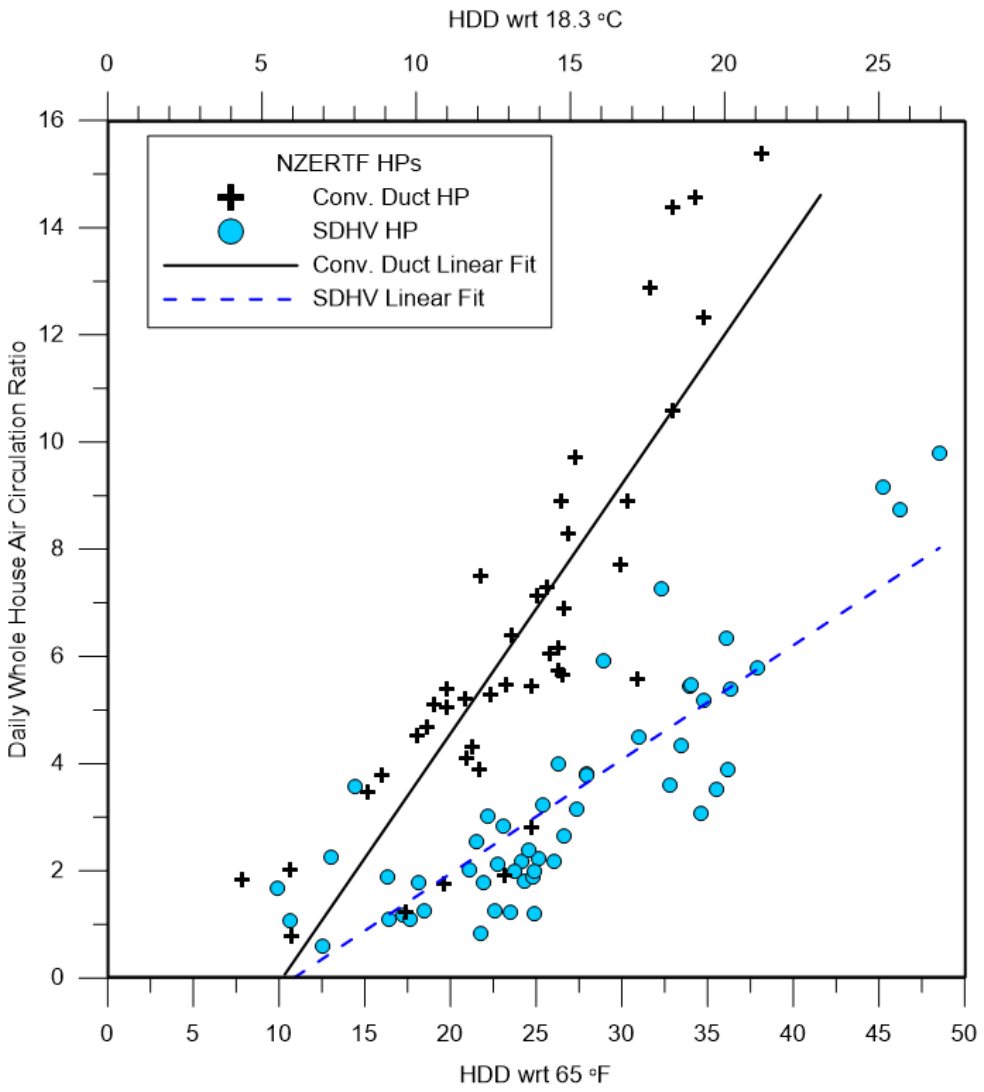

Figure 35: Daily heating air circulation ratio 


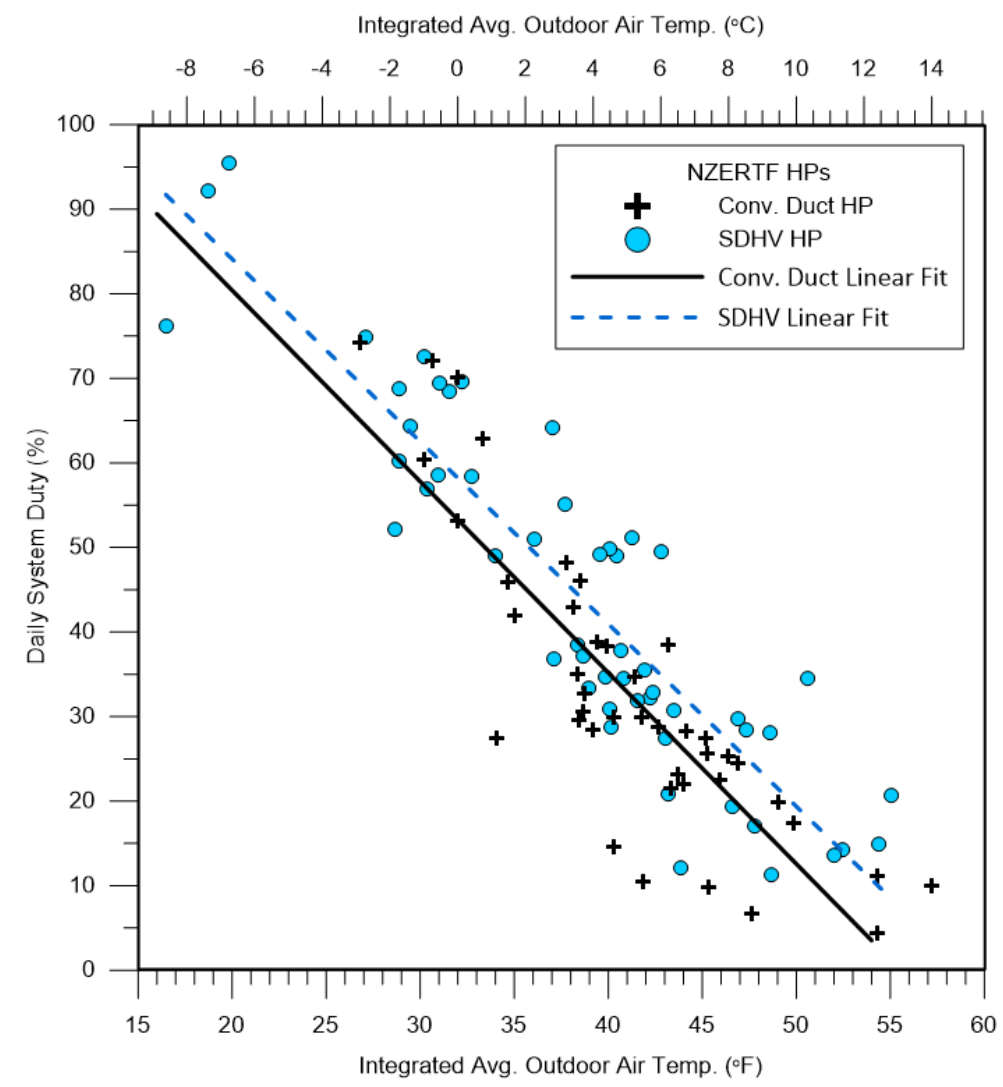

Figure 36: Heating daily system percent duty

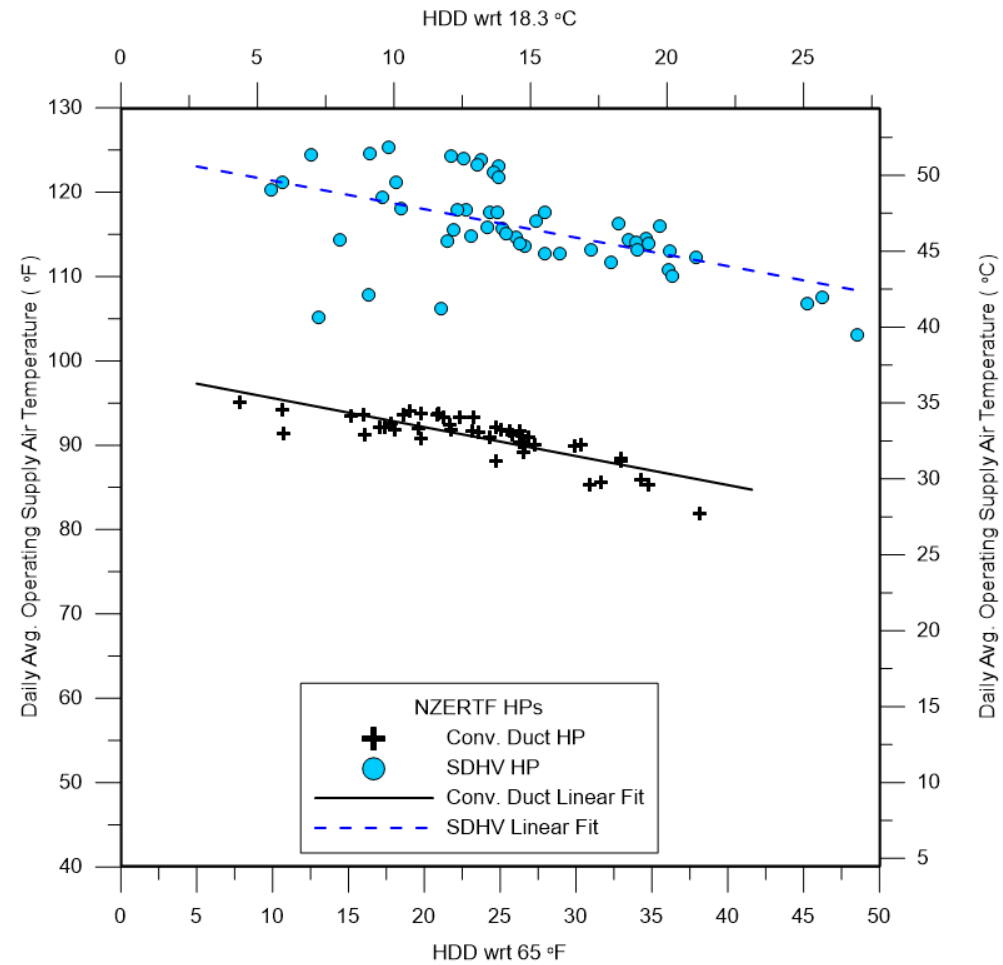

Figure 37: Heating average operating supply air temperatures 


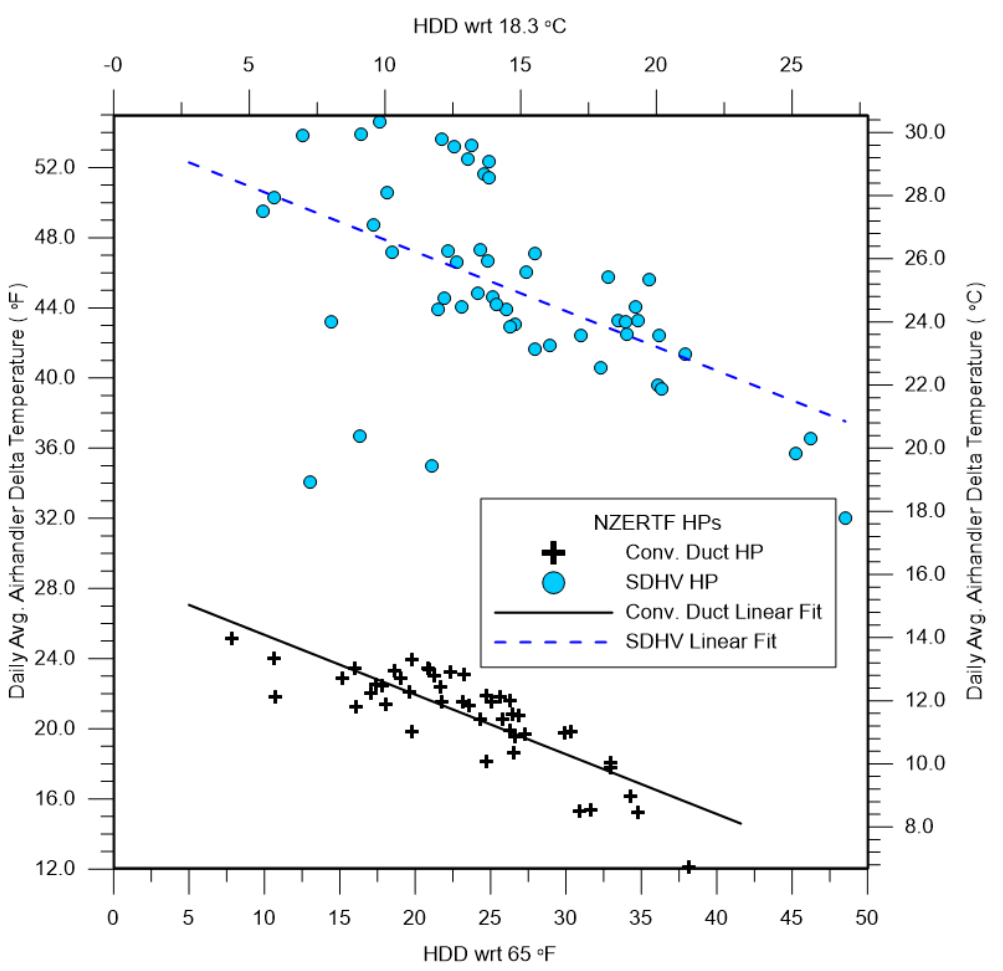

Figure 38: Heating average operating indoor unit air temperature change

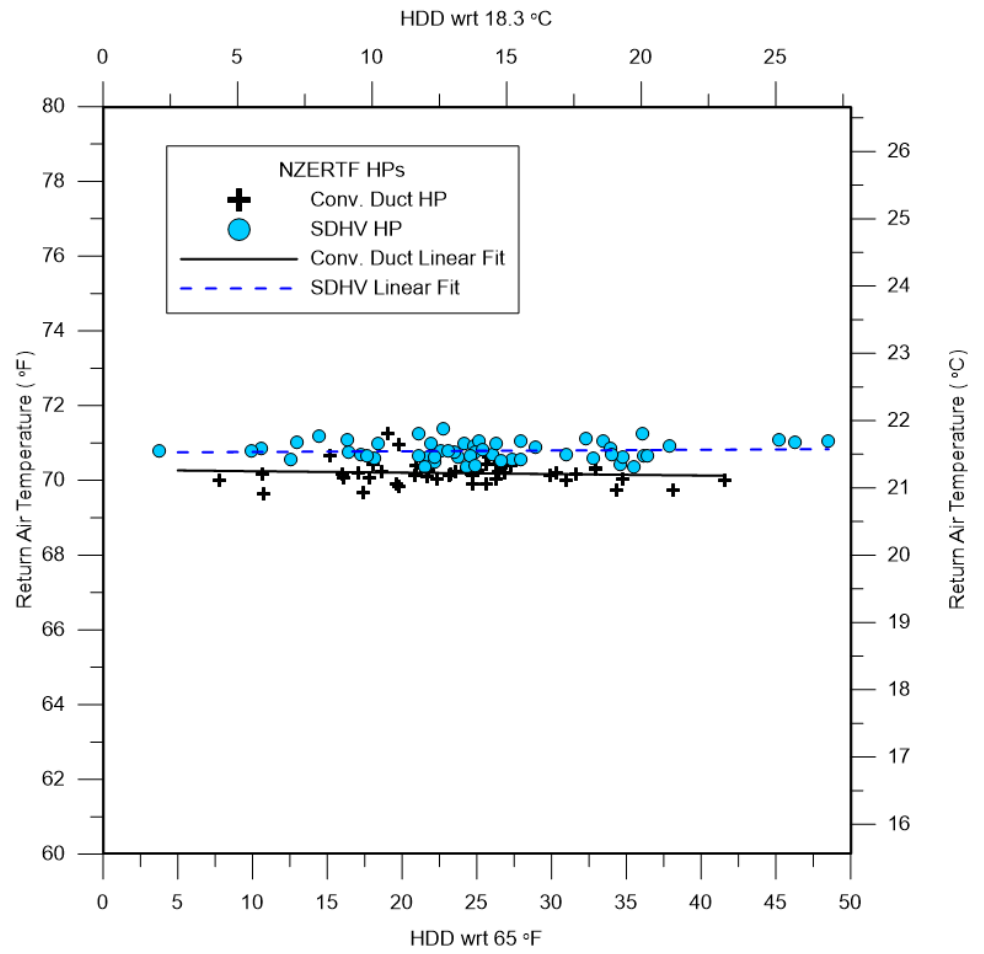

Figure 39: Heating daily average operating return air temperature

\subsubsection{Heating Standby Energy Use}

Heating standby energy use for the indoor unit is shown in Fig. 40; the SDHV indoor air

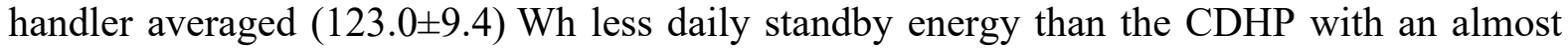


constant demand of 4 and $11 \mathrm{~W}$ for the SDHV and CDHP, respectively (Fig. 41). The SDHV outdoor unit standby energy use (Fig. 42) did not have a constant demand with HDD but increased at the colder outdoor temperatures (Fig. 43) due to electric resistance compressor sump heating. The decrease in CDHP energy use at high HDD was due to less standby time. The CDHP has an external electric resistance sump heater, but it was never energized during the heating season. The overall result for total standby energy use is shown in Fig. 44; the SDHV system consumed an average of $(255.5 \pm 46.0)$ Wh less standby energy daily than the CDHP.

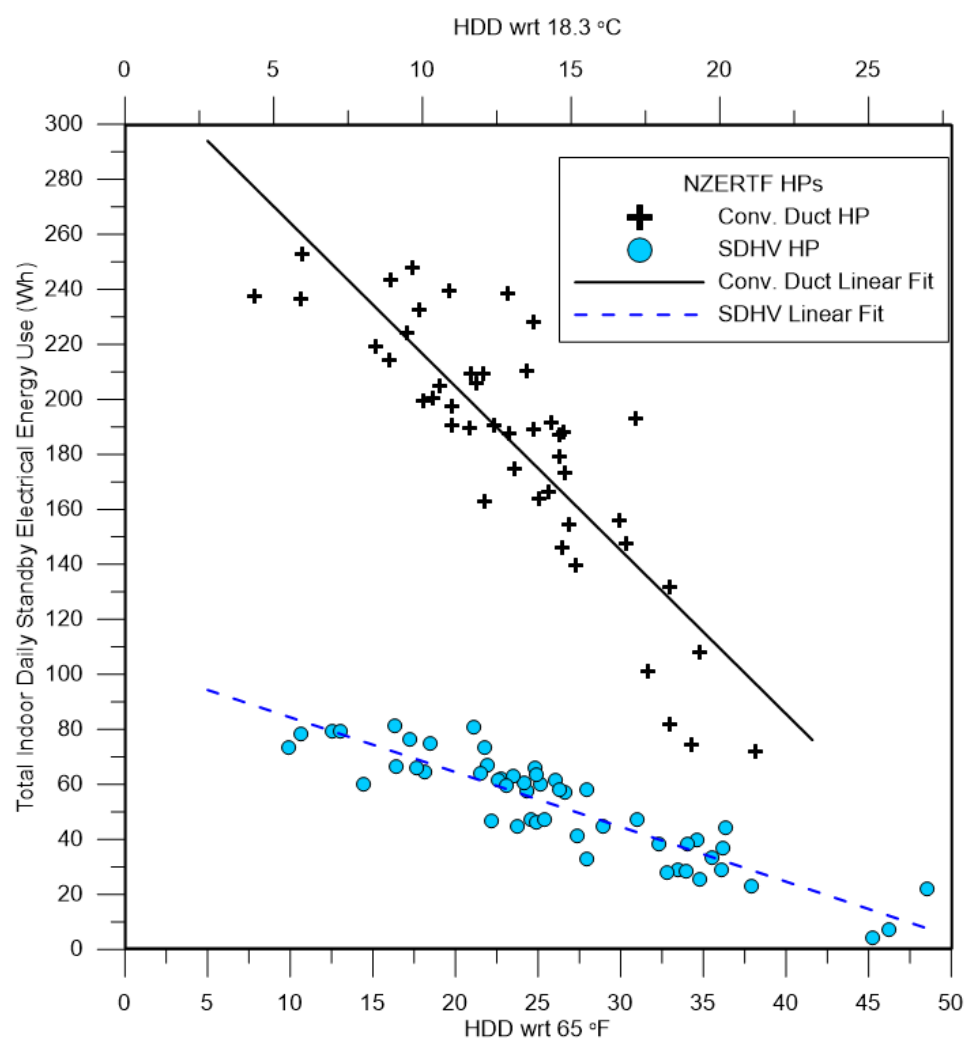

Figure 40: Heating ID unit standby energy use 


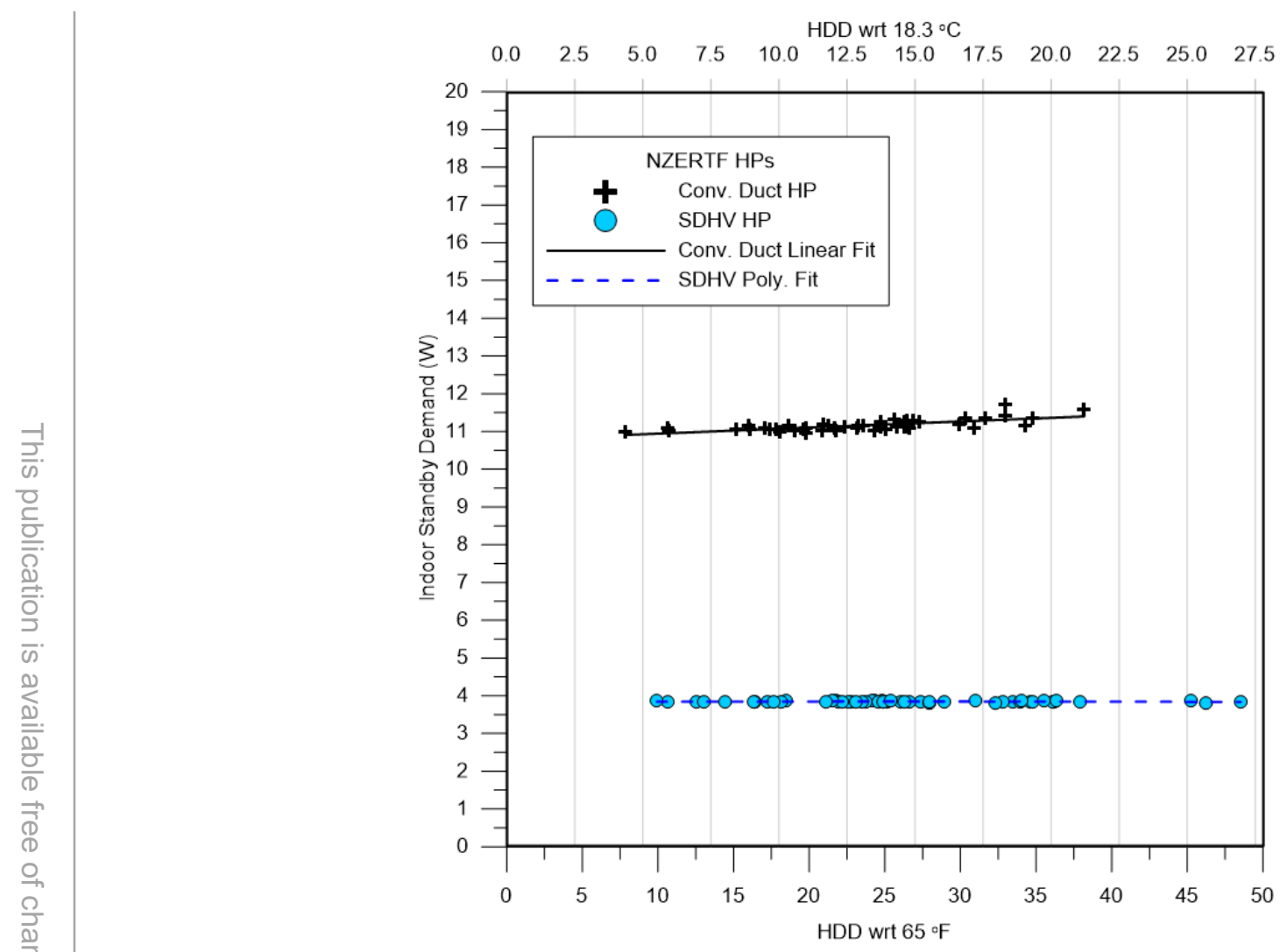

Figure 41: Heating ID unit standby power demand

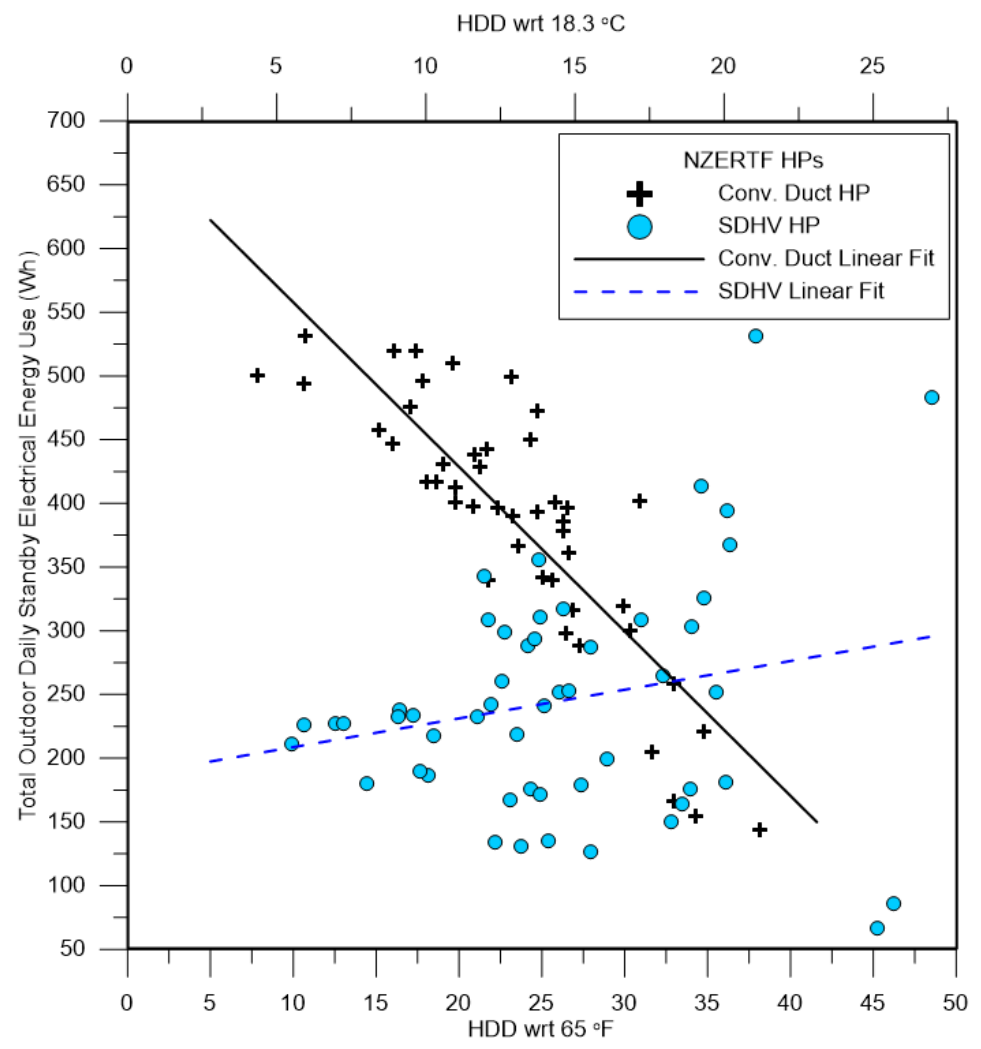

Figure 42: Heating OD unit standby energy use 


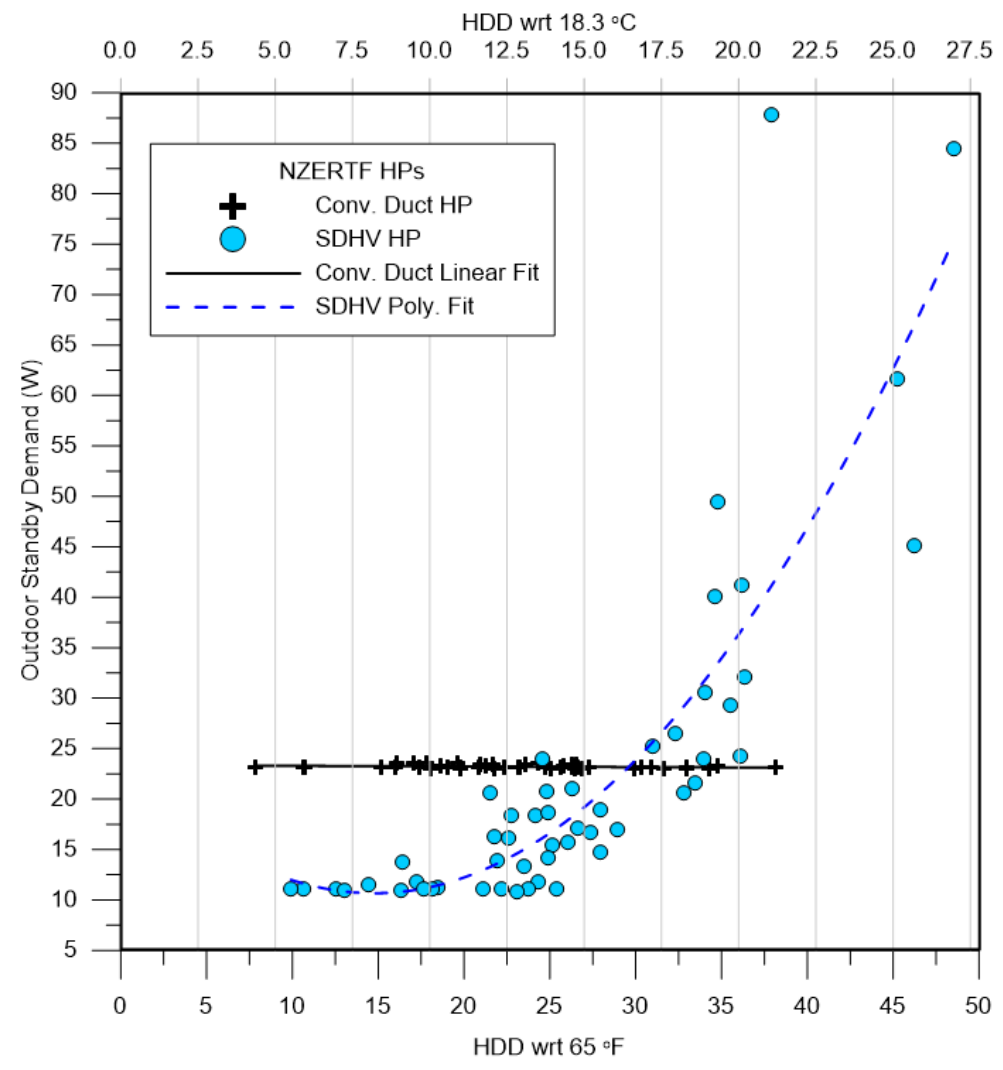

Figure 43: Heating OD unit standby power demand 


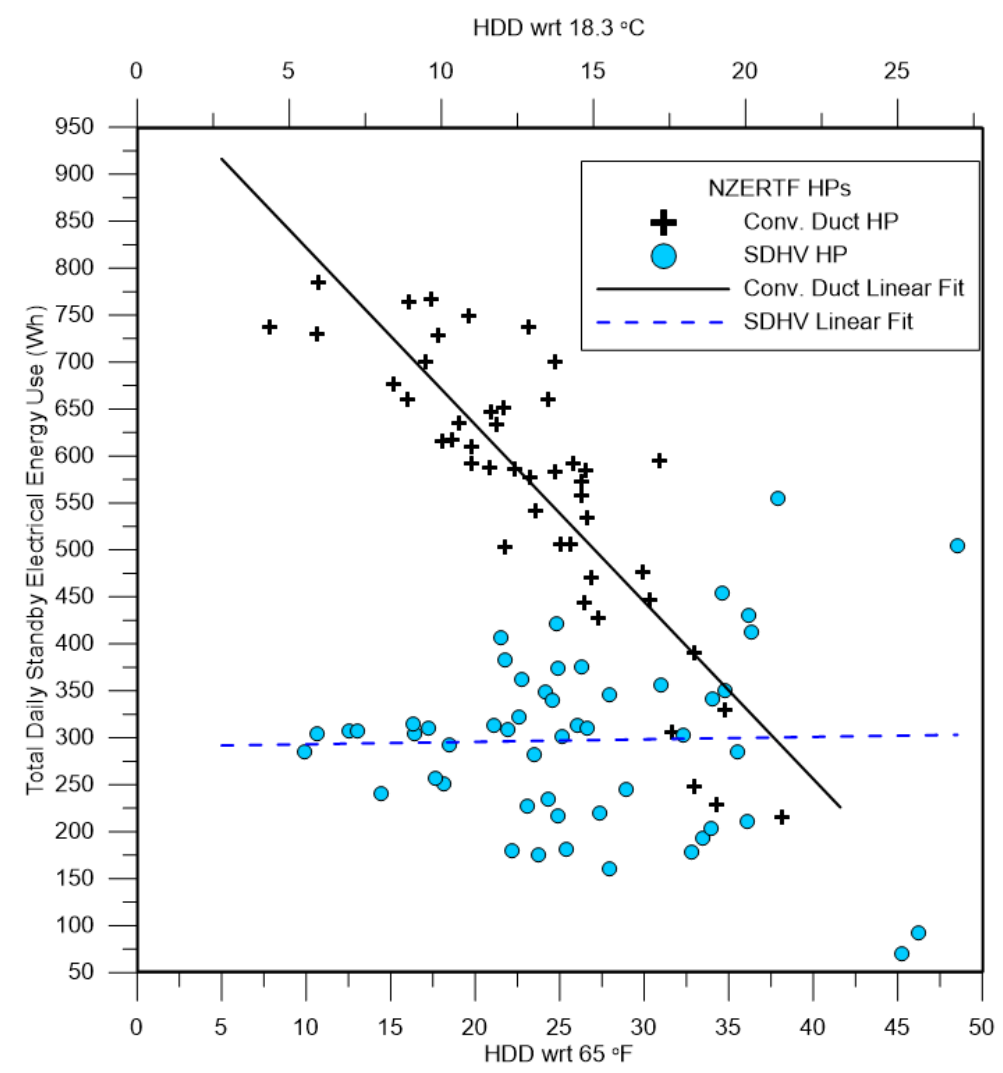

Figure 44: Heating system standby total energy use

\subsubsection{Heating Efficiency}

Figure 45 shows the daily average heating COP as a function of the HDD. High supply air temperatures were produced by the SDHV system which reduce the "cold blow" effect that many people complain about when a new heat pump is retrofitted to a hot air furnace system (Bouchelle et al. 2000). These high temperatures were meant to reduce the "cold blow" effect, but these high temperatures had a direct effect on heating COP. As a remedy to the excessively high supply air temperatures, new firmware was uploaded to the SDHV system controller and produced major changes in heating efficiency and supply air temperature (Fig. 46). The CDHP had an average daily heating COP of $(1.9 \pm 0.4)$ compared to $(1.8 \pm 0.9)$ for the SDHV with original firmware; the CDHP average heating COP was statistically equal to that of the SDHV running the original firmware. The SDHV system with the new firmware averaged a heating COP of (2.5 \pm 1.1$)$. The heating COP of the new firmware SDHV was $(0.6 \pm 0.18)$ higher than the CDHP over comparable temperature conditions. Further testing of the new firmware would be needed to reduce its standard error and improve the comparison with the CDHP.

Figure 47 shows daily average heating COP of the two systems as a function of outdoor air dry-bulb temperature. This figure illustrates the large improvement in heating COP due to a change in the SDHV firmware. This figure also shows that the SDHV system experienced the coldest heating days during the test period, but this did not reduce its COP as compared to the CDHP. 


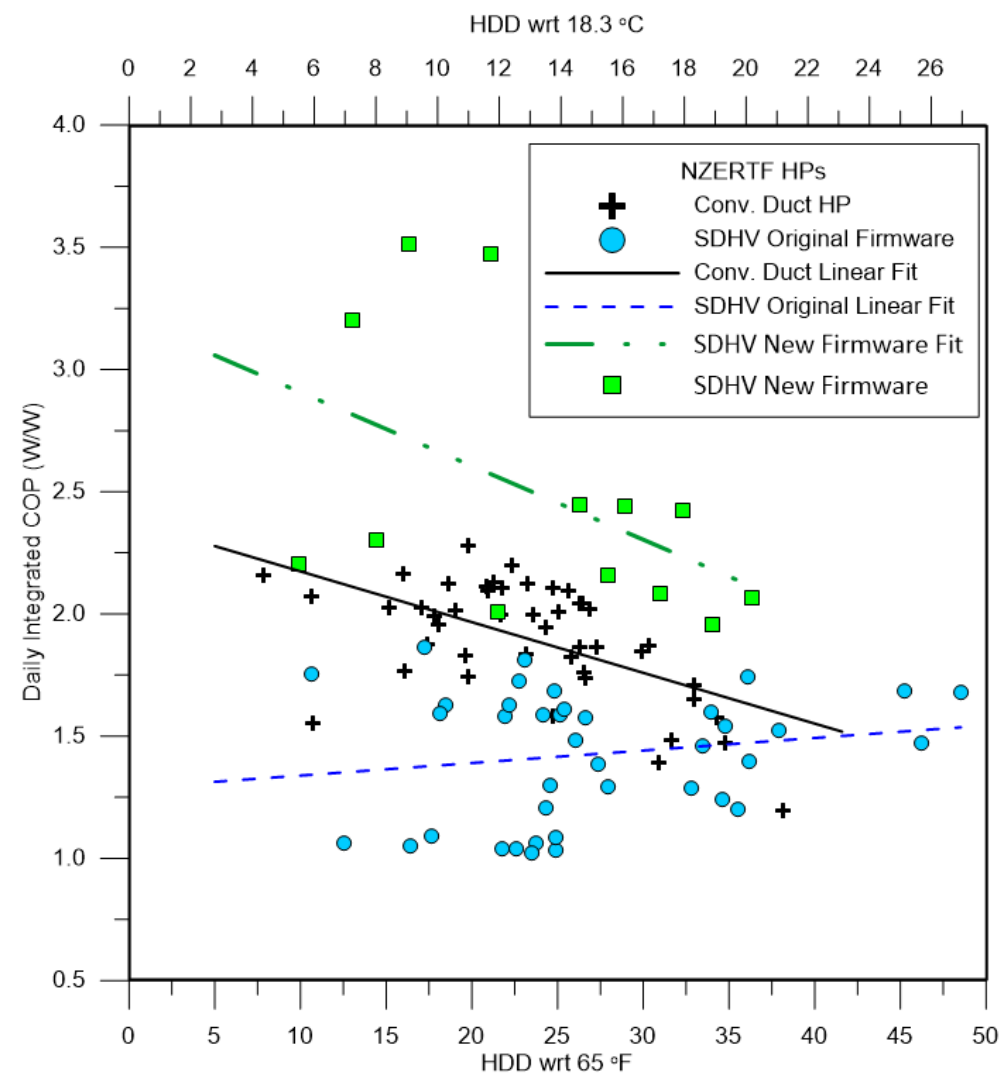

Figure 45: Heating COP versus HDD with original and new firmware

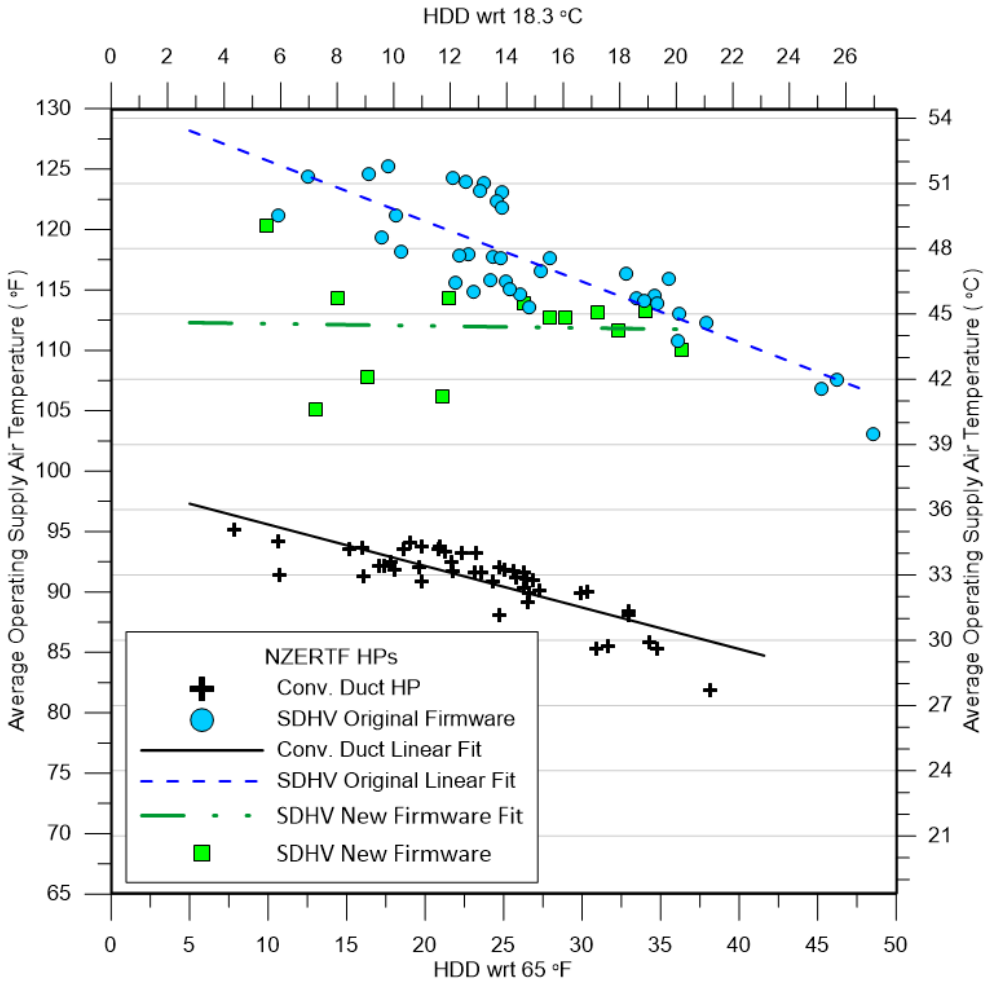

Figure 46: Heating supply air temperatures with original and new firmware 


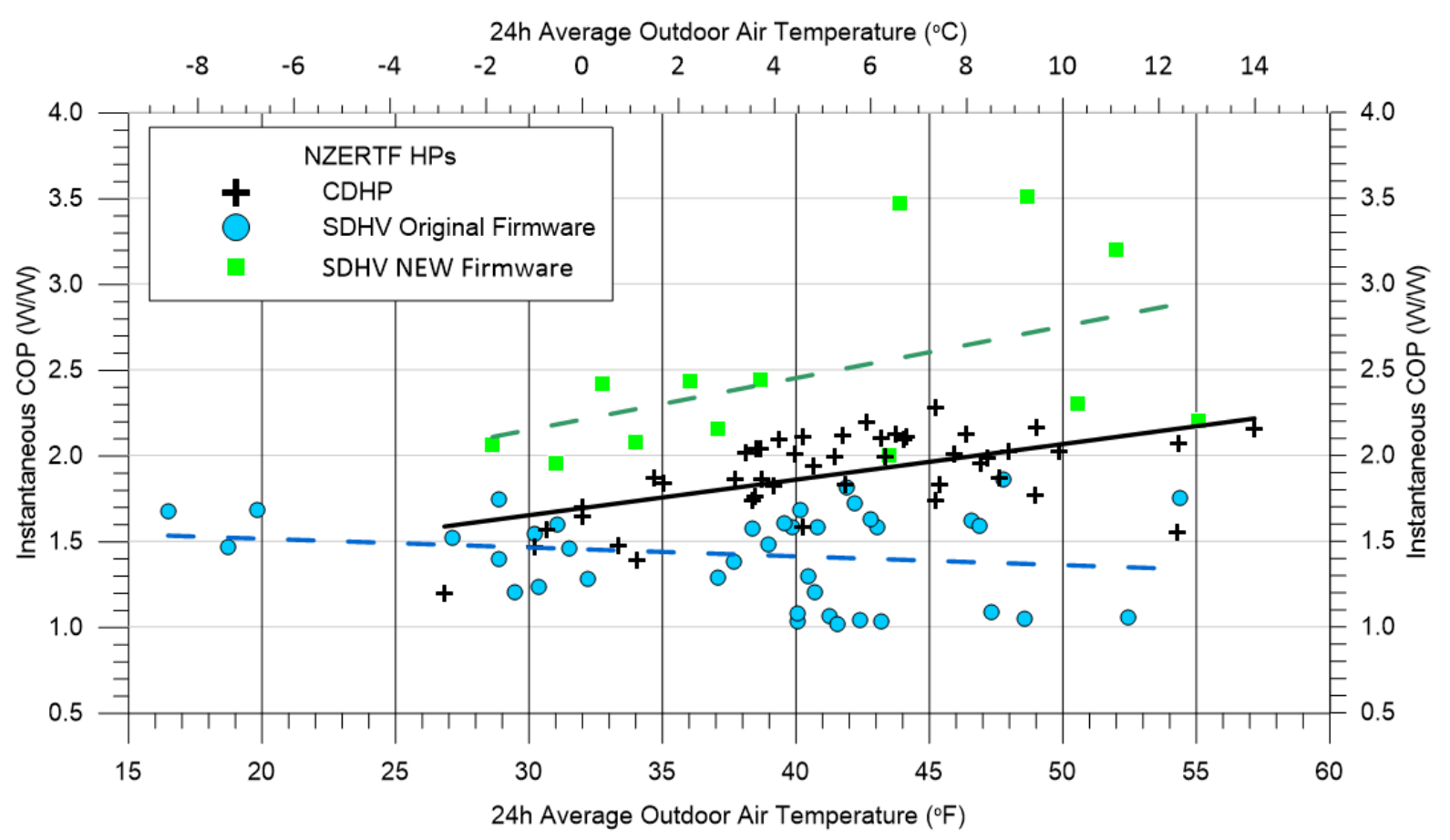

Figure 47: Heating COP as a function of daily average outdoor air temperature

\subsubsection{Defrost Performance}

The conventional system and the small duct high velocity system performed defrost operations to remove the buildup of frost on the outdoor heat exchangers. The CDHP defrost control was set to perform a defrost every 90 minutes when needed. Observations of the CDHP defrost showed that the defrost operation would occur every 90 minutes of accumulated compressor runtime when the outdoor temperature was below $35^{\circ} \mathrm{F}$.

The SDHV system takes a different approach to the traditional reverse cycle defrost; when it senses frosting conditions, the unit employs hot gas bypass to the outdoor heat exchanger while allowing the indoor unit to remain operating. If the control detects that the defrost parameter is not resolved by hot gas bypass, then the system resorts to a full reverse-cycle defrost. The SDHV system uses no auxiliary electrical resistive heating elements in the air stream.

The SDHV system used an average of (624 \pm 254$)$ Wh less defrost energy per day than the CDHP (Fig. 48). To understand how the two systems perform defrosts, Fig. 49 shows a heating capacity plot that begins at the start of a defrost and ends at the end of a second defrost; the two systems perform a defrost, run at steady-state for a while, then defrost again. The time scales are not equivalent because the steady-state runtime between defrosts is very different for these examples. The top axis is the time scale for the CDHP, about $7000 \mathrm{sec}(1 \mathrm{~h} 57 \mathrm{~min})$, and the bottom axis is the time scale for the SDHV HP, about $22000 \mathrm{sec}(6 \mathrm{~h} 6 \mathrm{~min})$.

The CDHP defrost begins while the heating capacity before defrosting is $4195 \mathrm{~W}$ $\left(14314 \mathrm{Btu} \mathrm{h}^{-1}\right)$. Figure 50 shows a combined plot of heating capacity, resistive heat power, ID blower power, and OD coil temperature during the CDHP defrost from 0 to $195 \mathrm{sec}$. Heating capacity is shown as a negative value to differentiate it from cooling capacity. At the initiation of defrost the outdoor fan is turned off as the refrigerant reversing valve is energized 
as in cooling mode operation. About 15 seconds pass before electric resistive heat engages $(5000 \mathrm{~W})$, and the indoor blower ramps up airflow rate and thus blower power demand moves up to approximately $400 \mathrm{~W}$. A few seconds after resistive heat turns $\mathrm{ON}$ and the indoor blower ramps up, the outdoor coil temperature starts to rise. The outdoor coil temperature reaches a peak of $26.8^{\circ} \mathrm{C}\left(80.2^{\circ} \mathrm{F}\right)$ before the reversing valve switches back to heating mode $(170 \mathrm{sec})$. Resistive heat remains energized after the reversing valve switches to heating mode until turning OFF at $195 \mathrm{sec}$ as normal heating resumes. The $5 \mathrm{~kW}$ nominal supplementary resistive heat is not enough to prevent "cold blow" during the defrost; heating capacity goes positive, indicating a cooling effect upon the house, from 105 to $175 \mathrm{sec}$. This defrost consumed $278 \mathrm{Wh}$ of electrical energy.

The SDHV defrost begins while the heating capacity before defrosting is $2696 \mathrm{~W}\left(9200 \mathrm{Btu} \mathrm{h}^{-}\right.$ $\left.{ }^{1}\right)$. Figure 51 shows a combined plot of heating capacity, resistive heat power, ID blower power, and OD coil temperature during the SDHV defrost from 0 to $760 \mathrm{sec}$. Heating capacity is shown as a negative value to differentiate it from cooling capacity. At the initiation of defrost the outdoor fan is turned off as the refrigerant reversing valve is energized as in cooling mode operation. After about 100 seconds, the indoor blower ramps all the way OFF and the outdoor coil temperature starts to rise. The outdoor coil temperature reaches a peak of $29.7^{\circ} \mathrm{C}\left(85.5^{\circ} \mathrm{F}\right)$ before the reversing valve switches back to heating mode $(760 \mathrm{sec})$. The "cold blow" effect seen for the CDHP during the defrost is absent here; heating capacity never goes positive, as the indoor blower energizes at $860 \mathrm{sec}$ to resume normal heating operation. This defrost consumed 265 Wh of electrical energy.

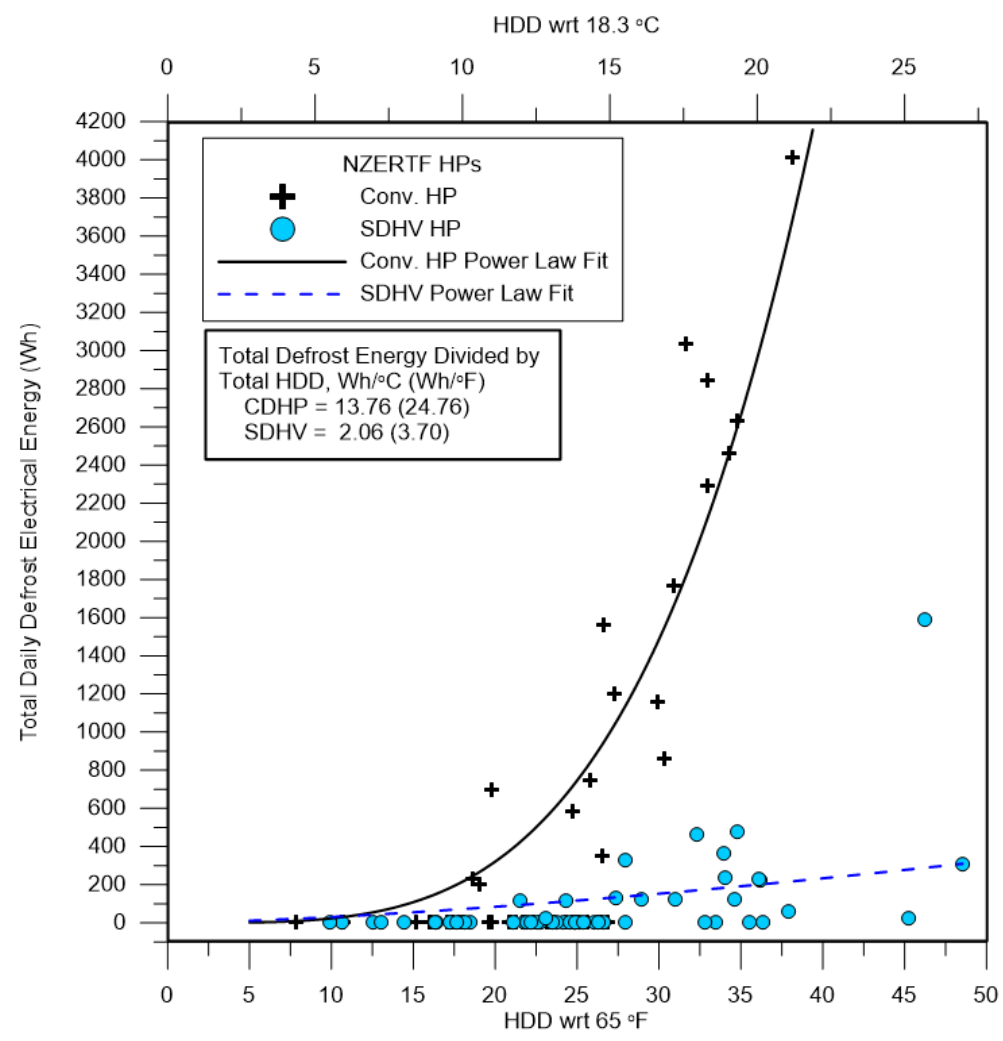

Figure 48: Heating daily defrost energy use 


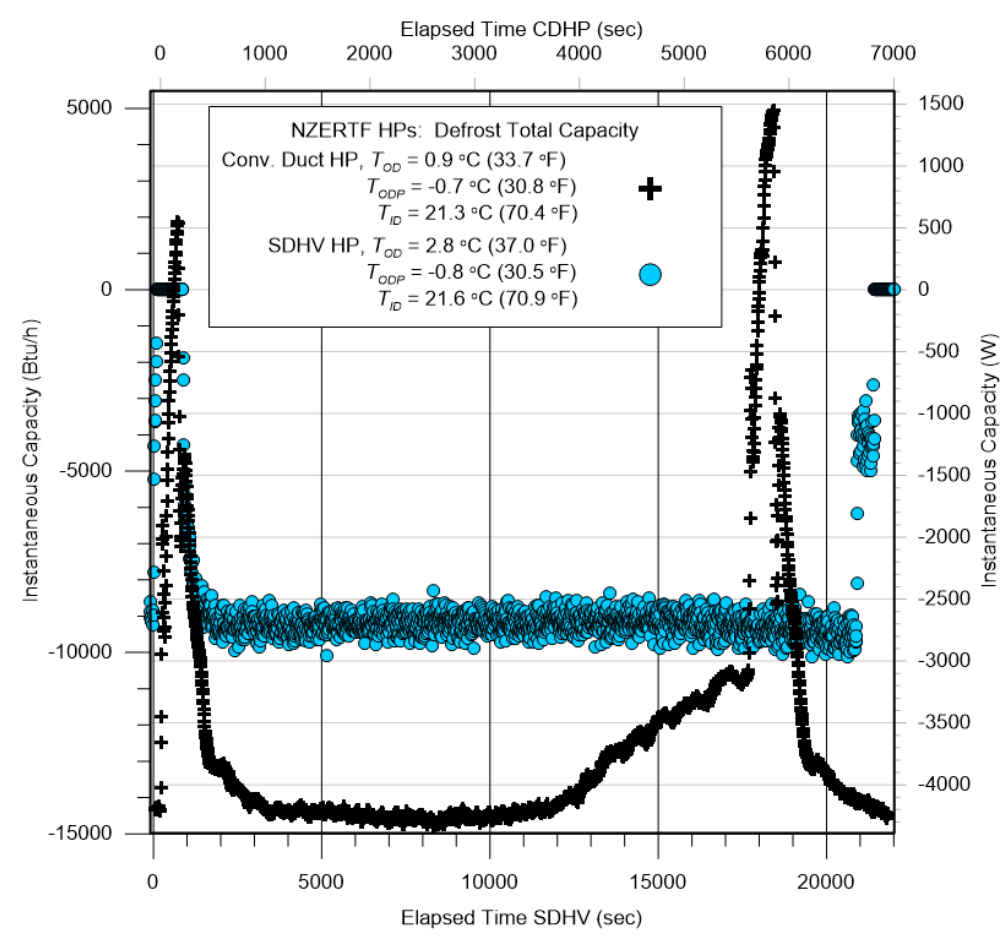

Figure 49: Example defrost heating capacity

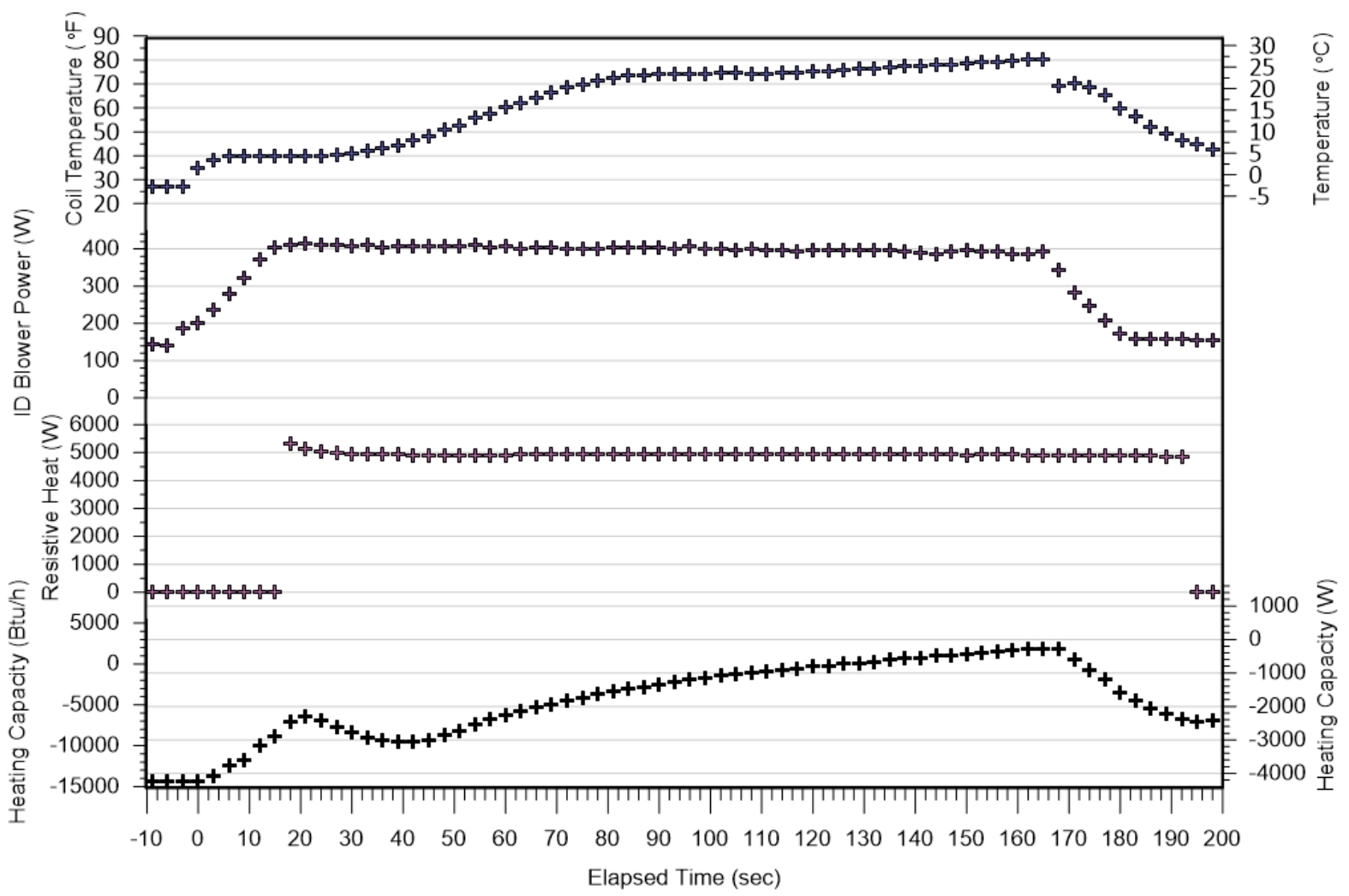

Figure 50: CDHP defrost characteristics 


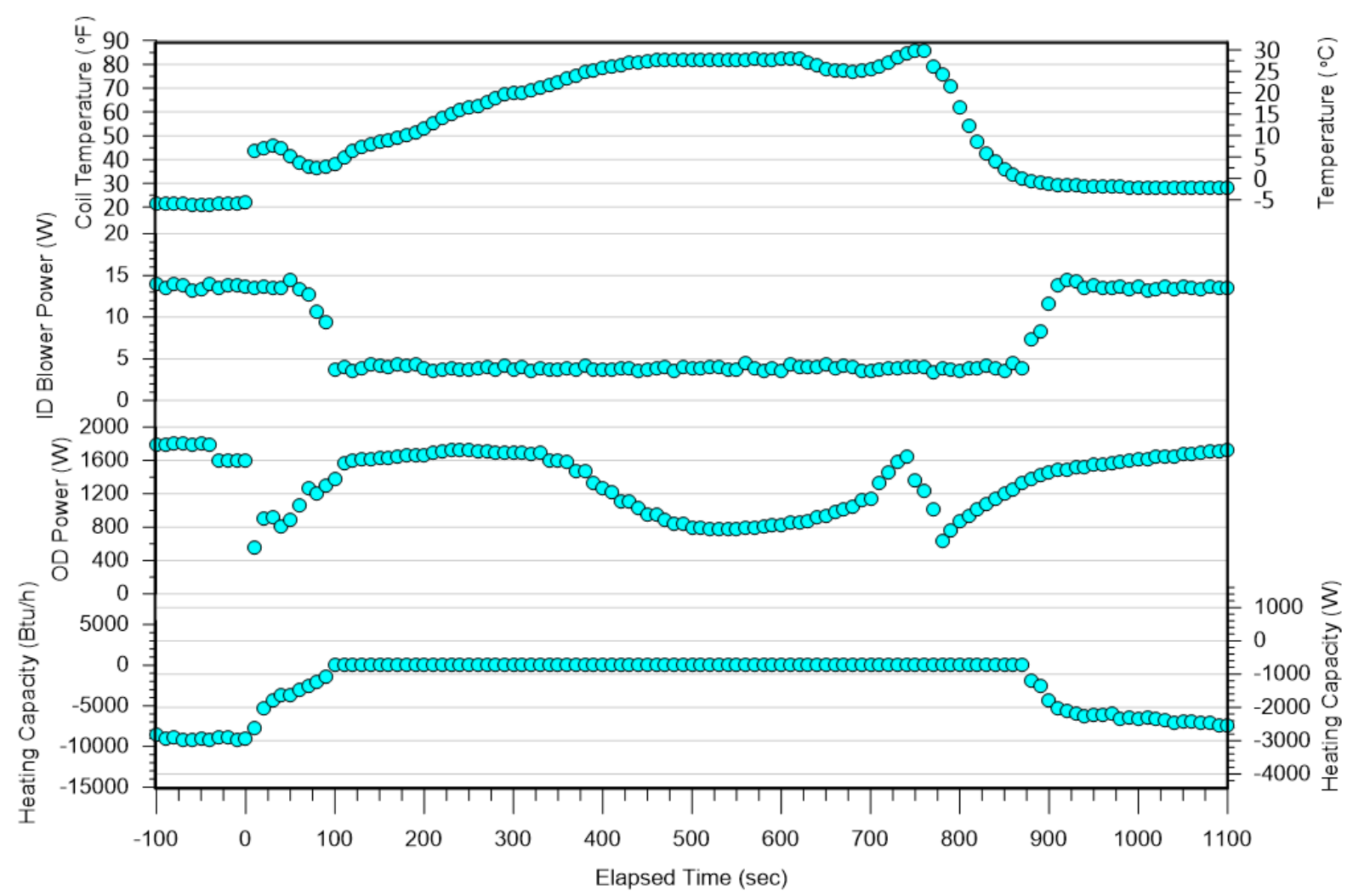

Figure 51: SDHV defrost characteristics

Figure 52 looks at a frosting interval for both systems in more detail; heating capacities are shown as negative numbers. The SDHV, before the previous defrost and not shown on this figure, had a heating capacity of $(2700 \pm 166) \mathrm{W}\left((9215 \pm 568) \mathrm{Btu} \mathrm{h}^{-1}\right)$ and total power demand of $(1766 \pm 70) \mathrm{W}$. After defrost and at steady-state again as shown in Fig. 52, the heating capacity was $(2709 \pm 145) \mathrm{W}\left((9244 \pm 496) \mathrm{Btu} \mathrm{h}^{-1}\right)$ as power dropped to $(1695 \pm 86) \mathrm{W}$ while maintaining capacity. During frosting (end of defrost to start of next defrost) the capacity was maintained at $(2703 \pm 148) \mathrm{W}\left((9222 \pm 504) \mathrm{Btu} \mathrm{h}^{-1}\right)$ and power demand averaged $(1672 \pm 88) \mathrm{W}$. One minute before the initiation of the next defrost, heating capacity averaged $(2684 \pm 156) \mathrm{W}$ $\left((9159 \pm 532) \mathrm{Btu} \mathrm{h}^{-1}\right)$ with total power demand averaging (1636 \pm 8$) \mathrm{W}$. During frosting the average heating capacity decreased less than $1 \%$ and the average total power demand decreased $3.5 \%$.

The CDHP, before the previous defrost, had a heating capacity of $(4194 \pm 19) \mathrm{W}$ $\left((14310 \pm 64) \mathrm{Btu} \mathrm{h}^{-1}\right)$ and total power demand of $(2003 \pm 424) \mathrm{W}$ (Fig. 52). After defrost and at steady-state again $(1100$ to $3750 \mathrm{sec})$, the heating capacity was $(4244 \pm 69) \mathrm{W}$ $\left((14480 \pm 234) \mathrm{Btu} \mathrm{h}^{-1}\right)$ and power demand was $(2011 \pm 52 \mathrm{~W}$. One minute before the initiation of the next defrost, heating capacity averaged $(3144 \pm 47) \mathrm{W}\left((10729 \pm 162) \mathrm{Btu} \mathrm{h}^{-1}\right)$ with total power demand averaging $(1925 \pm 10) \mathrm{W}$. During the last part of the frosting interval (3750 to $5610 \mathrm{sec})$, the capacity was dropping at an average of $36.2 \mathrm{~W}\left(123.4 \mathrm{Btu} \mathrm{h}^{-1}\right)$ each minute. Average heating capacity dropped by $26 \%$ during the frosting interval and before the next defrost began. 


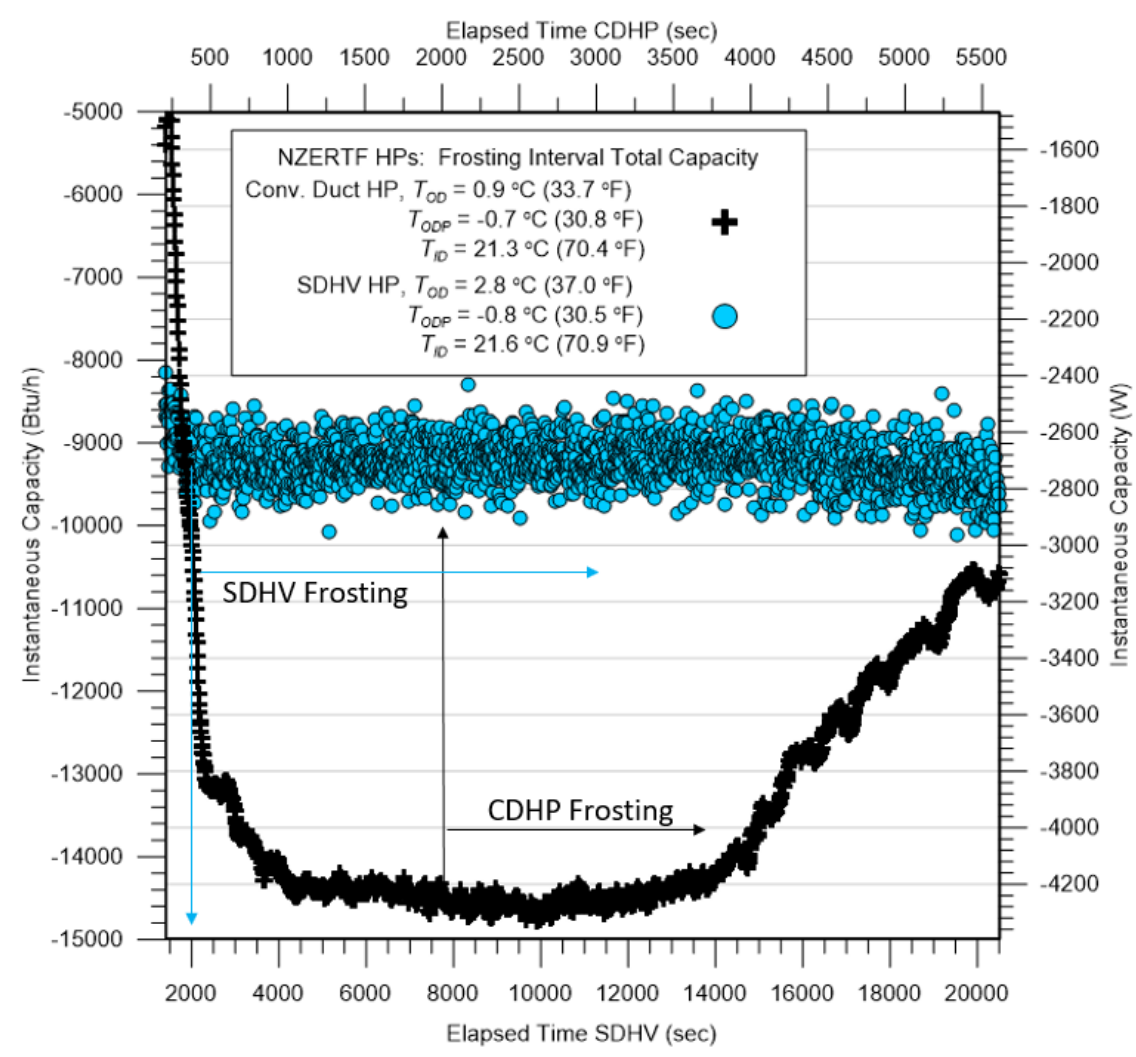

Figure 52: Frosting interval heating capacity

\section{CONCLUSIONS AND RECOMMENDATIONS}

The objective of this study was to determine if the high velocity system could provide comparable energy use efficiency to the conventional system. The results of this study showed that the small duct high velocity system did meet the required loads while doing so with slightly greater efficiency; the average cooling COP was $(0.396 \pm 0.113)$ higher and the average heating COP was statistically equal. This near equal performance was realized in spite of the fact that the SEER and HSPF ratings of the SDHV were $11 \%$ and $8 \%$ lower than the CDHP, respectively. New firmware was provided to improve the heating performance at the end of the heating season; this greatly improved the heating performance of the high velocity system. The improvement was produced due to lowered condensing temperatures which produced lower compressor power demand. Its average heating COP went from (1.8 \pm 0.9$)$ to $(2.5 \pm 1.1)$ at a $95 \%$ confidence level. The new firmware heating COP averaged (1.05 \pm 0.23$)$ higher than the old firmware over comparable temperature conditions.

The frosting and defrosting characteristics of these two systems were totally different. The SDHV avoided rapid capacity losses due to frosting by using the hot gas bypass to reduce the frosting effect on capacity. The SDHV used no electric resistance backup heat, yet it provided comfortable conditions without "cold blow" during defrost. The CDHP showed a steady decrease in heating capacity during frosting with comparable drops in supply air temperature. The CDHP defrosted with a full reverse cycle while applying electric resistance heat to prevent "cold blow." Although the two systems used comparable amounts of energy during the heating season to remove frost from the outdoor heat exchanger, the SDHV frosting/defrosting controls 
provided more consistent supply air temperatures and avoided electric resistance heat installation. The better frosting defrost temperatures of the SDHV were produced at the cost of more system complexity due to the added hot gas bypass valving.

Most of the time, the SDHV operated at very low air flow rates with total external static pressures (ESP) in the range of 37 to $63 \mathrm{~Pa}(0.15$ to 0.25 inches WG). Even though this ductwork was a high-pressure system designed for $2039 \mathrm{~m}^{3} \mathrm{~h}^{-1}(1200 \mathrm{cfm})$, because of its variable capacity and low air flows at low load, the system operated in the static pressure range of a well-designed conventional duct system. The CDHP operated the majority of the time at low compressor speeds with ESP in the range of 50 to $125 \mathrm{~Pa}(0.2$ to 0.5 inches WG). These results raise the question of whether a conventional, multi-speed or variable-speed heat pump with an ECM blower could work well with this kind of high velocity duct system? Potential future work will include investigation of a hybrid system that uses round duct trunk lines with an optimized version of the SDHV flexible take-offs and supplies. The round duct is much easier to join and seal than rectangular ducting, plus less raw material is used to produce a given flow area with round duct.

\section{Acknowledgments}

We would like to acknowledge the support and hard work of our Engineering Technician staff who were invaluable in obtaining the data used in this report. We thank Mr. Arthur Ellison, Mr. John Wamsley, and Mr. Luis Luyo.

\section{REFERENCES}

ACCA, 2012a, Manual J: Residential Load Calculation, $8^{\text {th }}$ Edition, Version 2, Air Conditioning Contractors of America, 2800 Shirlington Rd, Suite 300, Arlington, VA USA 22206.

ACCA, 2012b, Manual D: Residential Duct Systems, $2^{\text {nd }}$ Edition, Air Conditioning Contractors of America, 2800 Shirlington Rd, Suite 300, Arlington, VA USA 22206.

AHRI, Performance Rating of Unitary Air-Conditioning and Air-Source Heat Pump Equipment, 2017, Air-Conditioning Heating and Refrigeration Institute, 2111 Wilson Blvd., Suite 500,Arlington, VA 22201 USA. http://www.ahrinet.org/App_Content/ahri/files/STANDARDS/AHRI/AHRI_Standard_210$240 \quad 2017$ add1.pdf

ASHRAE Std. 62.2-2010, Ventilation and Acceptable Indoor Air Quality in Residential Buildings- (ANSI Approved), American Society of Heating, Refrigerating and AirConditioning Engineers, 1791 Tullie Circle, N.E., Atlanta, GA 30329.

M.C. Baechler, J. Williamson, T Gilbride, P. Cole, M. Hefty, and P. M. Love, 2010, High Performance Home Technologies: Guide to Determining Climate Regions by County, PNNL 17211, Building America Best Practices Series, Vol. 7.1.

https://www1.eere.energy.gov/buildings/publications/pdfs/building_america/ba_climateguide 7 1.pdf.

Elizabeth Balke, Gregory Nellis, Sanford Klein, Harrison Skye, Vance Payne and Tania Ullah, 2018 Detailed energy model of the National Institute of Standards and Technology Net-Zero Energy Residential Test Facility: Development, modification, and validation, 
Science and Technology for the Built Environment, 24:7, 700-713.

https://doi.org/10.1080/23744731.2017.1381828

R. W. Besant and Y. Asiedu, 2000, Sizing and balancing air duct systems, ASHRAE Journal. https://www.semanticscholar.org/paper/Sizing-and-balancing-air-duct-systems-BesantAsiedu/56fe8e48450bb084dd00518246bf09d7d7d1586c.

M.P. Bouchelle, D.S. Parker, M.T. Anello, and K.M. Richardson, 2000, Factors influencing space heat and heat pump efficiency from a large-scale residential monitoring study, Proceedings of 2000 summer study on energy efficiency in buildings, ACEEE. http://www.fsec.ucf.edu/en/publications/html/FSEC-PF-362-01/

Building America Program, 2019, Building America Publication and Product Library, https://www1.eere.energy.gov/library/default.aspx?page=2\&spid=2.

L.G. Caldas and L.K. Norford, 2003, Genetic algorithms for optimization of building envelopes and the design and control of HVAC systems, ASME Transactions, Vol. 125, 34351. https://doi.org/10.1115/1.1591803

J. B. Cummings and C. R. Withers Jr., 2014, Making the Case for Oversizing VariableCapacity Heat Pumps, Florida Solar Energy Center, FSEC-PF-459-14, presented at 2014 ACEEE Summer Study on Energy Efficiency in Buildings.

http://fsec.ucf.edu/en/publications/pdf/FSEC-PF-459-14.pdf.

M. Davis, W.M. Healy, M. Boyd, L.C. Ng, W.V. Payne, H.M. Skye, and T. Ullah, 2014, Monitoring Techniques for the Net-Zero Energy Residential Test Facility, NIST Technical Note 1854. https://doi.org/10.6028/NIST.TN.1854.

A. H. Fanney, W. V. Payne, T. Ullah, L. Ng, M. Boyd, F. Omar, M. Davis, H. Skye, B. Dougherty, B. Polidoro, W. Healy, and E. Pettit, 2015, Net-Zero and Beyond! Design and Performance of NIST's Net-Zero Energy Residential Test Facility, Energy and Buildings, 101, 95-109. https://www.sciencedirect.com/science/article/pii/S0378778815003655

Herk, Anastasia. Mini-Split Heat Pump Evaluation and Zero Energy Ready Home Support. United States: N. p., 2017. Web. https://doi.org/10.2172/1340569.

S. Jorens, I. Verhaert, and K. Sorensen, 2018, Design optimization of air distribution systems in non-residential buildings, Energy \& Bldgs., 175, 48-56.

https://doi.org/10.1016/j.enbuild.2018.07.018

H. Kim, K. Nguyen, A. McGuinness, and T.V. Dai, 2019, Characterization of residential air distribution system performance for thermal comfort, NIST GCR 19-021, National Institute of Standards and Technology. https://doi.org/10.6028/NIST.GCR.19-021

Martin, E.; Withers, C.; McIlvaine, J.; Chasar, D.; Beal, D. 2018, Evaluating Moisture Control of Variable Capacity Heat Pumps in Mechanically Ventilated, Low-Load Homes in Climate Zone 2A, Cocoa, FL; Florida Solar Energy Center (FSEC). DOE/EE-1702. https://www.osti.gov/biblio/1421385-evaluating-moisture-control-variable-capacity-heatpumps-mechanically-ventilated-low-load-homes-climate-zone .

A. Poerschke and A. Rudd, 2016, Performance analysis of a modular small-diameter air distribution system. https://www.osti.gov/biblio/1240364 
A. Poerschke, R. Beach, T. Begg. 2017, Building America Case Study: Standard- Versus High-Velocity Air Distribution in High-Performance Townhomes, Denver, Colorado. United States.

https://www1.eere.energy.gov/buildings/publications/pdfs/building america/65316.pdf

A. Rudd and H.I. Henderson, 2007, Monitored Indoor Moisture and Temperature Conditions in Humid-Climate US Residences, ASHRAE Transactions 113(1), pp. 435-449.

https://consensus.fsu.edu/FBC/HMCW/Rudd-Henderson_Indoor_environment_data_DA-07046.pdf.

D.B. Shirey III, H.I. Henderson, and R.A. Raustad, 2006, Understanding the dehumidification performance of air-conditioning equipment at part-load conditions, FSECCR-1537-05, Florida Solar Energy Center, DOE/NETL Proj. No. DE-FC26-01NT41253. https://doi.org/10.2172/881342

R.J. Tsal, H.F. Behls, and R. Mangel, 1988, T-Method duct design, part I: optimization theory, ASHRAE Transactions, Vol. 94-2, Ottawa. 